\title{
The correlation between the electrocardiogram and the left ventriculogram
}

\author{
Citation for published version (APA):
}

Bär, F. W. H. M. (1982). The correlation between the electrocardiogram and the left ventriculogram.

[Doctoral Thesis, Maastricht University]. Rijksuniversiteit Limburg. https://doi.org/10.26481/dis.19820625fb

Document status and date:

Published: 01/01/1982

DOI:

$10.26481 /$ dis. $19820625 \mathrm{fb}$

Document Version:

Publisher's PDF, also known as Version of record

\section{Please check the document version of this publication:}

- A submitted manuscript is the version of the article upon submission and before peer-review. There can be important differences between the submitted version and the official published version of record.

People interested in the research are advised to contact the author for the final version of the publication, or visit the DOI to the publisher's website.

- The final author version and the galley proof are versions of the publication after peer review.

- The final published version features the final layout of the paper including the volume, issue and page numbers.

Link to publication

\footnotetext{
General rights rights.

- You may freely distribute the URL identifying the publication in the public portal. please follow below link for the End User Agreement:

www.umlib.nl/taverne-license

Take down policy

If you believe that this document breaches copyright please contact us at:

repository@maastrichtuniversity.nl

providing details and we will investigate your claim.
}

Copyright and moral rights for the publications made accessible in the public portal are retained by the authors and/or other copyright owners and it is a condition of accessing publications that users recognise and abide by the legal requirements associated with these

- Users may download and print one copy of any publication from the public portal for the purpose of private study or research.

- You may not further distribute the material or use it for any profit-making activity or commercial gain

If the publication is distributed under the terms of Article $25 \mathrm{fa}$ of the Dutch Copyright Act, indicated by the "Taverne" license above, 


\section{The correlation between the electrocardiogram and the left ventriculogram.}

Proefschrift

Ter verkrijging van de graad van doctor in de geneeskunde aan de Rijksuniversiteit Limburg te Maastricht op gezag van de rector magnificus Prof.Dr. H.C. Hemker, volgens besluit van het College van Dekanen in het openbaar te verdedigen in De Kleine Comedie, Tongersestraat 28 te Maastricht, op vrijdag 25 juni 1982 des namiddags te vier uur.

Fredericus Wilhelmus Hendricus Maria Bär geboren te Roermond. 
Promotores: Prof.Dr. H.J.J. Wellens

Prof.Dr. T. van der Werf

Referenten: Prof.Dr. H.E. Kulbertus

Prof.Dr. G.T. Meester

Prof.Dr. R.S. Reneman

The publication of the thesis was financially supported by the Netherlands Heart Foundation and Rescar (stichting ter bevordering reseach cardiologie) Maastricht.

The cover of this thesis has been designed by Chris Voskamp. 
To Mitzi and our four.

And to my father who set the example and who is following my example. 



\section{Contents}

Chapter 1

page

Introduction

Chapter 2

Review of the literature

a. The correlation between the electrocardiogram and the left ventriculogram 3

b. Left ventricular wall motion assessment

\section{Chapter 3}

Material and methods

a. Patients $\quad 23$

b. The electrocardiogram 25

c. Cardiac catheterization 28

d. Measurements on the left ventriculogram 29

\section{Chapter 4}

Results

a. Definition and classification of normal and abnormal segmental wall motion 37

b. Segmental wall motion in relation to certain electrocardiographic patterns 40

1. Generall aspects 40

2. Myocardial infarction $\quad 42$

3. ST-segment 53

4. T-wave 57

Chapter 5

Discussion of the results 61

a. Segmental wall motion assessment 61

b. The electrocardiogram 64

Chapter 6

Conclusions

Chapter 7

Samenvatting in het nederlands 



\section{Preface}

This thesis is the result of four years of collecting data from the Catheterization Laboratory.

After obtaining peace, I was able to concentrate on this subject.

It is a study which I performed along with my daily work in the Department of Cardiology in the Annadal Hospital, Maastricht. It was only possible because of continuous support of all members of the "Capaciteitsgroep Cardiologie". I was driven by Prof. H. Wellens as the "basic stimulus" and Prof. T. van der Werf as the "extra stimulus". They supported and advised me in many hours of their time. The assistance of the technical and paramedical staff of the catheterization laboratory was most appreciated, especially the help of $\mathrm{Mr}$. G. Schrouff for programming the "Digitizer". I owe a great deal to Miss A. van den Dool for her careful assistance in collecting data.

Dr. P. Brugada, who has interpreted all electrocardiograms and who was always willing to help, should not be forgotten. The role of Ir. P. Dassen in producing results should be mentioned. He was able, with inimitable patient ways, to translate my confused and continuous questions into computer language, resulting in correct answers. Also Mr. H. Jas, Ir. L. Strijbosch, Ir. A. Volovics and Mrs. M. Heddle have to be thanked for their technical advices. Miss J. van Beek and Mr. C. Evers and his photographic team played an important role in the completion of the illustrations. Mr. C. Voskamp designed the cover and the lay-out of this thesis.

A special recognition goes to Miss A. Lemmens, my secretary, who typed this manuscript without complaints. She did a fantastic job. I want to thank my parents and father-in-law. For them this thesis is as much of importance as to me. It is a pity that my mother-in-law is not able to join us. She would have been proud. Finally, most grateful I am to my wife Mitzi, she supported me in many ways, and to my children, Jeananne, Jimmy, Dominique and Ginger, who missed me too often. Many, many thanks to you all. 



\section{Chapter 1}

\section{Introduction}

In the process of assessing and treating patients with cardiac symptoms, information about the function of the different parts of the left ventricular $(\mathrm{LV})$ wall is of fundamental importance in decision making. Such knowledge is not only of value in determining prognosis as far as life expectancy and working capacity are concerned, but is also essential in the decision to intervene surgically and in predicting cardiac improvement after operation.

At the present time, this information is obtained by visualizing the LV wall motion by expensive investigations such as left ventriculography or cardiac scintigraphy. The purpose of this study was to define the value of the electrocardiogram (ECG), which is a much less expensive tool, to obtain more information about the function of the different parts of the LV wall.

In contrast to most previously published studies, we will not limit ourselves to a study of the relation between Q-waves and LV segmental wall motion, but also report our findings on the relation between $\mathrm{LV}$ segmental wall motion and other $\mathrm{ECG}$ abnormalities, such as ST-T segment changes.

It was tempting to concentrate on patients with coronary artery disease only, because they constituted the majority of our patient population and it in this group of patients that decisions have to be made on the risks and benefits of cardiac surgery and other intervention techniques. However, the purpose of our investigation was to evaluate the ECG as a predictor of LV wall motion abnormalities, not only in patients with coronary artery disease, but also in patients with heart disease of other aetiologies.

Recently a new and more accurate method for LV wall motion assessment has been developed in Stanford (1). One of the goals of our study was to define this method quantitatively in order to make general use possible.

In chapter 2 previous studies on the relationships between electrocardiografic findings and $\mathrm{LV}$ wall motion are reviewed. In this chapter the different electrocardiographic criteria used in the previous studies are discussed. Methods of assessing $\mathrm{LV}$ wall motion are discussed as well. The value and limitations of the different methods of $\mathrm{LV}$ wall motion assessment are critically evaluated.

Information about patients studied and methods used is given in chapter 3 .

The results of our investigation are described in chapter 4 .

A critical analysis of the results is given in chapter 5 .

Conclusions are drawn in chapter 6 .

De samenvatting in het nederlands staat in hoofdstuk 7. 


\section{Chapter 2}

\section{Review of the literature on the correlation between the electrocardiogram and left ventriculography}

"Left ventriculography is very similar to electrocardiography: both of these diagnostic procedures tend to express, though through different modalities, the same "fait accompli", i.e., the consequences that the obstructive or occlasive artherosclerotic process have had on the myocardium. A yet unknown (and certainly hard to define) threshold value has to be reached and surpassed before these functional tests will begin to show any deterioration under resting conditions" Gensini (2).

\section{a. The correlation between the electrocardiogram and the left ventriculogram}

In patients with coronary artery disease a relation has been described between abnormall Q-waves on the ECG and asynergy of the left ventricle as found during left ventriculography.

The first correlations between findings on the ECG and LV abnormalities in coronary heart disease were made in post-mortem studies (3-16). Fenichel and Kugell (10), Wilson and co-workers (15), and Myers and co-workers (16) established the basis for the association between myocardial necrosis and $\mathrm{Q}$-wave abnormalities. They recognized that the association was high, but not absolute. Horan (9) found a sensitivity of $61 \%$ and a specificity of $89 \%$. An abnormal Q-wave was present 339 times out of 1184 in their patient population. Two hundred and fifty-three of these 339 patients had signs of an old myocardial infarction when examined at necropsy. In 86 of the postmortem patients with Q-waves, no myocardial infarction was found.

The introduction of left ventriculography permitted demonstration of the presence of abnormalities of LV wall motion during life (17-22). This in turn, stimulated interest in the potential value of the ECG in predicting the sites of ventricular asynergy. Gorlin et al (23) were the first to establish a correlation between the ECG and the presence and site of ventricular wall motion abnormalities.

Several definitions for normal and abnormal wall motion are used in the literature. The definitions used in our study can be summarized as follows:

A. Synergy: normal wall motion of the left ventricle.

B. Asynergy: abnormal wall motion.

If asynergy is present, it is subdivided into three categories:

a. Hypokinesis: reduced wall motion.

b. Akinesis: absence of wall motion .

c. Dyskinesis: paradoxical wall motion.

In our study hyperkinesis was not considered.

In the seventies, several authors have studied the relation between abnormalities on the ECG (and vectorcardiogram) and abnormalities in LV myocardial contraction. Data from the nine articles on this subject are summarized in tables I to III. 
Table I shows the ECG criteria used in the different studies for diagnosing a myocardial infarction ("infarct"-ECG). Only study 1 included ST-segment elevation among their ECG criteria. In this table, the groups of patients studied are given, and the criteria used for exclusion of patients.

Table I also indicates the method used for LV wall motion assessment and whether a mono-; always $30^{\circ}$ right anterior oblique (RAO) projection, or biplane ventriculography; $30^{\circ} \mathrm{RAO}+60^{\circ}$ left anterior oblique (LAO) projection, was used. Finally, the sequence of the procedure followed during cardiac catheterization is listed.

Table I.

Data from 9 studies on the relation berwes ECO ond left ventricular wall motion abmormalities $(24-32)$

\begin{tabular}{|c|c|c|c|c|c|c|}
\hline Sirudy & $\begin{array}{l}\text { ECG criterion } \\
\text { used }\end{array}$ & $\begin{array}{l}\text { Type af } \\
\text { heary } \\
\text { disease }\end{array}$ & $\begin{array}{l}\text { Enciusion } \\
\text { crateria }\end{array}$ & $\begin{array}{l}\text { Method } \\
\text { L.V hall } \\
\text { assess } \\
\text { ment }\end{array}$ & $\begin{array}{l}\text { Mono or } \\
\text { biplane } \\
\text { L.V-graphy }\end{array}$ & $\begin{array}{l}\text { Procedure } \\
\text { sequence }\end{array}$ \\
\hline $\begin{array}{l}1 . \\
(24)\end{array}$ & $\begin{array}{l}Q \geqslant 0.04 \text { sec: } \\
I_{1} A V F, V_{1}-V_{6} \\
Q S: I, A V F, V_{1}-V_{6} \\
R \geqslant 0.04 \text { sec: } V_{1} \\
\text { ST alevation: } \\
\text { Convex upwards } \\
\text { ST-segment with } \\
\text { terminal negative } T \\
\text { in the presence of } \\
\text { a } O \text {. }\end{array}$ & $\begin{array}{l}\text { Cor.art } \\
\text { disease }\end{array}$ & $\begin{array}{l}\text { LBBB } \\
\text { Hemiblock } \\
\text { WPW } \\
\text { LWH } \\
\text { RVH }\end{array}$ & $\begin{array}{c}\text { Herman } \\
\text { (17) }\end{array}$ & Biplane & $\begin{array}{l}\text { 1. LV-graphy } \\
\text { 2. Cor angio }\end{array}$ \\
\hline $\begin{array}{l}2 . \\
(25)\end{array}$ & NYHA (33) & $\begin{array}{c}\text { Cor.art. } \\
\text { disease } \\
\text { +t } \\
\text { Asymergy }\end{array}$ & $\begin{array}{l}\text { Valwe } \\
\text { disease }\end{array}$ & Herman & Monoplane & $\begin{array}{l}\text { 1. Cor angio } \\
\text { 2. LV Vraphy }\end{array}$ \\
\hline $\begin{array}{l}3 \\
(26)\end{array}$ & $\begin{array}{l}\text { No crileria } \\
\text { given }\end{array}$ & $\begin{array}{l}\text { Intierior } \\
\text { MII. }\end{array}$ & $\begin{array}{l}\text { LBBH } \\
\text { Hemiblock } \\
\text { LVH } \\
\text { RVH } \\
\text { Pacing }\end{array}$ & Herman & Monoplane & $\begin{array}{l}\text { 1. LV-graphy } \\
\text { 2. Cor-angio }\end{array}$ \\
\hline $\begin{array}{l}4 \\
(27)\end{array}$ & Massie (34) & $\begin{array}{l}\text { Corstat. } \\
\text { disearse }\end{array}$ & Nonc & Herman & Monoplane & $\begin{array}{l}\text { 1. LV-graphy } \\
\text { 2. Cor.angio }\end{array}$ \\
\hline $\begin{array}{l}5 \\
(28)\end{array}$ & Pipberger (35) & Asynergy & None & Unknown & Monoplane & Unknown \\
\hline $\begin{array}{l}6 . \\
(29)\end{array}$ & $\begin{array}{l}Q \geqslant 0.04 \mathrm{sec} \\
A V V_{0} V_{2} \cdot V_{6} \\
\text { OS: } V_{2} \cdot V_{6}\end{array}$ & $\begin{array}{l}\text { Cour art. } \\
\text { disense } \\
\text { Cardio- } \\
\text { nyyopathy }\end{array}$ & $\begin{array}{l}\text { Valve } \\
\text { disease } \\
\text { Cong. } \\
\text { disease }\end{array}$ & Herman & Monoplane & $\begin{array}{l}\text { 1. LV-graphy } \\
\text { 2. Cor angio }\end{array}$ \\
\hline
\end{tabular}


Table I.

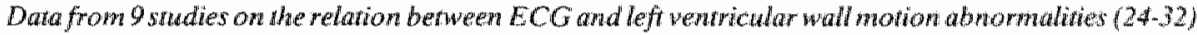

\begin{tabular}{|c|c|c|c|c|c|c|}
\hline Study & $\begin{array}{l}\text { ECGoriferia } \\
\text { ssed }\end{array}$ & $\begin{array}{l}\text { Type of } \\
\text { heart } \\
\text { disease }\end{array}$ & $\begin{array}{l}\text { Exclusion } \\
\text { criteria }\end{array}$ & $\begin{array}{l}\text { Merhod } \\
\text { LVwall } \\
\text { assosso } \\
\text { merer }\end{array}$ & $\begin{array}{l}\text { Mona-or } \\
\text { biphame } \\
\text { LV-graphy }\end{array}$ & $\begin{array}{l}\text { Procederte } \\
\text { sequence }\end{array}$ \\
\hline $\begin{array}{l}7 . \\
30)\end{array}$ & $\begin{array}{l}Q \geqslant 0.04 \mathrm{sec}: \\
V_{2}-V_{6} \\
Q S: V_{2}-V_{6} \\
Q>25 \% R: V_{2}-V_{4} \\
Q>15 \% R: V_{5}-V_{6} \\
R<2 \text { mm: } V_{3} \\
R<4 \text { mm: } V_{4} \\
\text { Loss of R: } V_{2}-V_{4}\end{array}$ & $\begin{array}{l}\text { Cor art. } \\
\text { Whease } \\
+ \\
\text { Asymergy }\end{array}$ & $\begin{array}{l}\text { LBBB } \\
\text { RBBB } \\
\text { Hemiblock } \\
\text { WPW } \\
\text { Hypert. } \\
\text { Severe } \\
\text { mitral } \\
\text { incomp. }\end{array}$ & Hetman & Monoplane & $\begin{array}{l}\text { 1. Cor angio } \\
\text { 2. LV-graplyy }\end{array}$ \\
\hline $\begin{array}{l}8 . \\
(31)\end{array}$ & $\begin{array}{l}Q \geqslant 0.04 \text { sec: } \\
1, V_{1}-V_{6} \\
Q S: V_{1}-V_{4} \\
Q>25 \% R: A V F \\
V_{1}-V_{4} \\
Q>15 \% R: I \\
V_{5}-V_{6} \\
\text { Loss of } R_{:}: V_{1}-V_{4}\end{array}$ & M.I. & $\begin{array}{l}\text { LBBB } \\
\text { RBBB } \\
\text { Hemiblock } \\
\text { WPW } \\
\text { LVH } \\
\text { RVH } \\
\text { Pacing } \\
\text { Hypert. } \\
\text { Post. and } \\
\text { Lat. M.t. }\end{array}$ & Herman & Monoplane & $\begin{array}{l}\text { 1. Cor angio } \\
\text { 2. LV-graphy }\end{array}$ \\
\hline $\begin{array}{l}9 \\
(32)\end{array}$ & 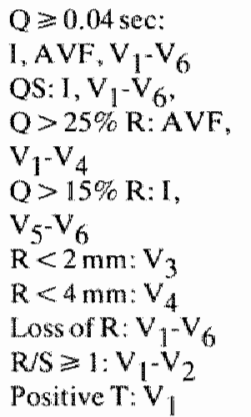 & $\begin{array}{l}\text { Corant } \\
\text { disease }\end{array}$ & $\begin{array}{l}\text { LBBB } \\
\text { RBBB } \\
\text { Hemiblock } \\
\text { WPW } \\
\text { LVH } \\
\text { RVH }\end{array}$ & $\begin{array}{c}\text { CASS } \\
(32)\end{array}$ & Biplane & Unknown \\
\hline
\end{tabular}

Abbreviations: $L V=$ left ventricular; LV-graphy $=$ left ventriculography; cor, art disease $=$ coronary artery disease; $\angle \mathrm{BBB}=$ left bundle branch block; $\mathrm{RBBB}=$ right bundle branch block; WPW = Wolff Parkinson White-syndrome; $\mathrm{LVH}=$ left ventricular hypertrophy; $\mathrm{RVH}=$ right ventricular hyperttophy; Cor angio = coronary angiography; $\mathrm{NYHA}=\mathrm{New}$ York Heart Association; Hypert.$=$ hypertenm sion; Post.$=$ posterior; Lat. $=$ lateral; M.I. $=$ myocardial infarction; Cong. disease $=$ congenital dise se; mitral incomp. = mitral incompetence. 
Table II gives data on the numbers of patients with asynergy, synergy, "infarct"ECG, the location of the myocardial infarction on the ECG and the number of patients having no documentation of infarction on the ECG ("normal"-ECG). Findings from each study are given in respect to the presence of an "infarct"-ECG in patients having asynergy of the left ventricle and the presence of a "normal"-ECG in patients having a normal contraction pattern of the left ventricle. If the data was available, subdivisions were made into the anterior, inferior and posterior LV wall.

Table II.

Data from 9 studies on the relation between ECG and left ventricular wall motion abnormalities (24-32)

\begin{tabular}{|c|c|c|c|c|c|c|c|c|c|}
\hline Situdy & $P t s$ & Asyrn. & Sywt. & M.I. & Local. & & NoM.I. & "Inf"ECG/Asyn & "Norm" ECGSYn \\
\hline $\begin{array}{l}1 . \\
\text { (24) }\end{array}$ & 123 & 84 & 39 & 77 & $\begin{array}{c}\mathrm{A} \\
\mathrm{I} \\
\mathrm{P} \\
\mathrm{A} / \mathrm{C} / \mathrm{P}\end{array}$ & $\begin{array}{r}40 \\
28 \\
5 \\
4\end{array}$ & 46 & $73 / 84$ & $35 / 39$ \\
\hline
\end{tabular}

\begin{tabular}{lllllllllll}
2. & 156 & 156 & $0 ?$ & 77 & $\mathrm{~A}$ & 21 & & & $\mathrm{~A}$ & $21 / 38$ \\
$(25)$ & & & & & $\mathrm{P}$ & 50 & 79 & $77 / 156$ & 1 & $50 / 80$ \\
\hline
\end{tabular}

3. $\quad \begin{array}{lllllll}52 & 40 & 12 & 52 & 1 & 52 & 0\end{array}$

(26)

\begin{tabular}{lllllllll} 
4. & 264 & 191 & 73 & 164 & $\begin{array}{c}\text { A } \\
1\end{array}$ & $\begin{array}{l}55 \\
82\end{array}$ & 100 & \\
$(27)$ & & & & & A/I & 27 & & \\
\hline 5. & 107 & 107 & 0 & 75 & & $?$ & 32 & $75 / 107$
\end{tabular}

(28)

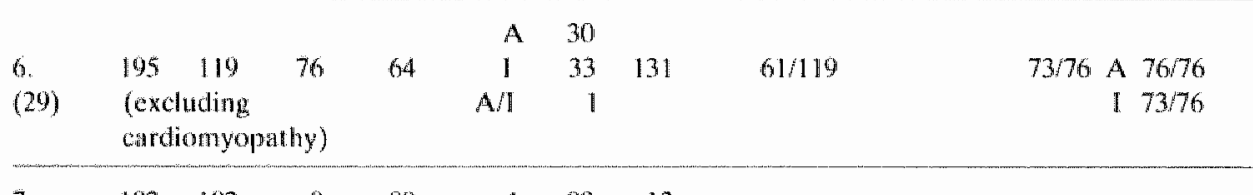

7. $\quad \begin{array}{lllllll}102 & 102 & 0 & 89 & \text { A } & 89 & 13\end{array}$

(30)

\begin{tabular}{lllllrrrr}
8. & 225 & 183 & 42 & 225 & A & 82 \\
$(31)$ & & & & & 100 & 0 \\
\hline
\end{tabular}

\begin{tabular}{|c|c|c|c|c|c|c|c|c|c|c|c|}
\hline \multirow{5}{*}{ (32) } & \multirow{5}{*}{200} & \multirow{5}{*}{152} & \multirow{4}{*}{48} & \multirow{3}{*}{84} & A & 31 & & \multirow{2}{*}{\multicolumn{2}{|c|}{$\begin{array}{c}\mathrm{A}+\mathrm{A} / \mathrm{I} \\
43 / 118 \\
\mathrm{I}+\mathrm{A} / \mathrm{I}\end{array}$}} & & \multirow[b]{2}{*}{ A $81 / 82$} \\
\hline & & & & & 1 & 25 & 116 & & & & \\
\hline & & & & & $\mathrm{P}$ & 9 & & $78 / 152$ & $36 / 103$ & $42 / 48$ & I $89 / 97$ \\
\hline & & & & & $\mathrm{A} / \mathrm{l} / \mathrm{P}$ & 19 & & & $P+I / P$ & & $P 83 / 87$ \\
\hline & & & & & & & & & $11 / 69$ & & \\
\hline
\end{tabular}

Abbreviations: Pts. = patients; Asyn. = asynergy; Syn. = synergy; M.I = myocardial infarction; Local. = localization; "Inf"ECG/Asyn. = "infarct". ECG/asynergy; "Norm"ECG/Syn. = "normal"-ECG/synergy, $\mathrm{A}=$ anterior: $\mathrm{I}=$ inferior; $\mathrm{P}=$ posterior. 
Table III gives information on the patients having asynergy in the presence of an "infarct"--ECG, and on the relation between asynergy in the corresponding LV wall segment and the "infarct"-ECG. Also the presence of asynergy in other segments than the corresponding ones in patients having an "infarct"-ECG is shown. Finally, asynergy in those patients having a "normal". ECG is listed.

Table III.

Data from 9 studies on the relation between ECG and left ventricular wall motion abnormalities (24-32)

\begin{tabular}{|c|c|c|c|c|}
\hline Study & Asyn. "Mn' $E C G$ & $\begin{array}{l}\text { Asyn. in corresp. } \\
\text { segm. "Inp'ECG }\end{array}$ & $\begin{array}{l}\text { Asyn in moresegm's } \\
\text { than corresp." } \\
\text { "hn" ECG }\end{array}$ & Asyn." "Norm" ECG \\
\hline
\end{tabular}

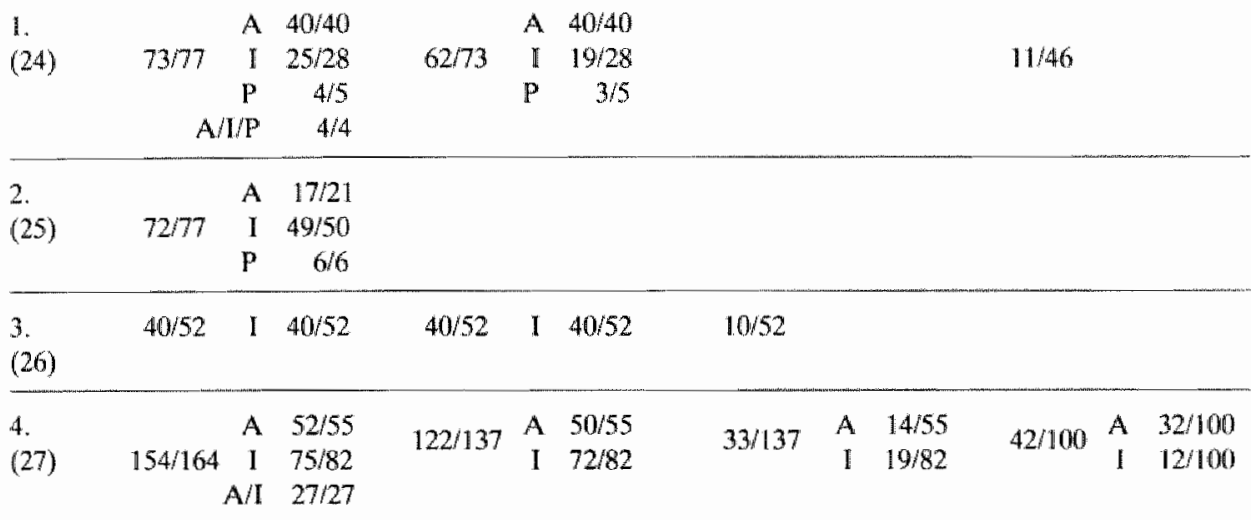

5.

$65 / 75$

(28)

$\begin{array}{lrrrrrr}6 . & \text { A } & 30 / 30 & 54 / 63 & \text { A } & 29 / 30 & \\ \text { (29) } & 61 / 64 & \text { I } & 30 / 31 & & 25 / 33 & 55 / 131 \\ \text { AI } & 1 / 1 & & \text { I } & & \end{array}$

7. No information a wailable.

(30)

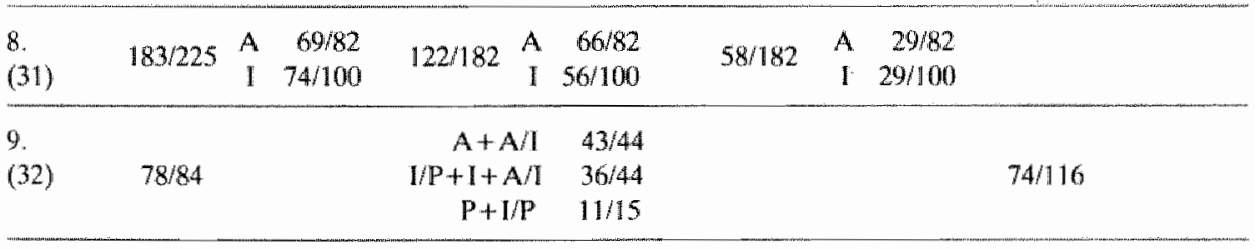

Abbrewiations: Asyn. = asynergy; "Inf" $\mathrm{ECG}=$ "infarct"-ECG; Corresp. = conresponding; Segm. segment; "Norm:"ECG = "normal"-ECG; $A=$ arterior; $1=$ inferior; $P=$ posterior. 
A short analysis of the nine previously reported studies on the relation between the electrocardiogram and left ventricular wall motion

\section{Siudy I}

In the study of Miller et al (24) a correlation was made between the resting ECG and LV wall motion.

They were the first group to publish data using biplane ventriculography. Their ECG criteria were not restricted to patients with $Q$-waves alone, but also included patients with ST-segment elevation. Of the 123 patients studied, 84 patients had asynergy of the left ventricle and 77 an "infarct"-ECG: 40 in the anterior, 28 in the inferior, 5 in the posterior wall, and 4 in more than one area.

If an "infarct"-ECG was present, 73/77 patients (95\%) had asynergy. It should be stressed that asynergy was present in $11 / 46$ patients (24\%) with a "normal"-ECG. Five patients had a posterior wall infarction on the ECG. One of these patients, nevertheless, had a normal contraction pattern, one other patient an abnormal contraction pattern in another segment. There was a good correlation between the site of the abnormal ventricular wall motion and the location of the Q-waves on the ECG: $62 / 73$ patients $(85 \%)$.

Although a $60^{\circ}$ LAO-projection was available in this study, no data was provided about abnormalities of the postero-lateral wall on the left ventriculogram.

Attention was given to the severity of asynergy in relation to the ECG. Q-wave location was found to be of importance to indicate the probability and severity of asynergy: $32 / 40$ patients $(80 \%)$ with anterior myocardial infarction on the ECG had akinesis or dyskinesis; while $10 / 28$ patients $(36 \%)$ with inferior infarction had akinesis or dyskinesis. If more precordial leads contained Q-waves, damage of the left ventricle was more severe. The presence of ST-segment elevation along with Q-waves was associated with akinesis or dyskinesis in $18 / 19$ patients $(95 \%)$. The degree of ST-segment elevation was not defined.

\section{Study 2}

Howard et al (25) selected 156 patients with coronary artery disease. They all had an occlusion of at least one coronary artery and an abnormal contraction pattern of the left ventricle. The purpose of their investigation was to study the value of vectorcardiographic and electrocardiographic findings in patients having definite asynergy of the left ventricle. Only in $49 \%$ of their 156 cases was an "infarct"- ECG present. This in contrast with $76 \%$ of their cases when the vectorcardiogram was used for making the diagnosis of myocardial infarction. Findings diagnostic of 2 coexisting infarctions were observed in $71 \%$ of the vectorcardiograms, and in $35 \%$ of the ECGs in 51 patients with 2 areas of LV dyskinesis.

If one considers their selection criteria, one would expect to find only patients with abnormal LV contraction patterns. However, in one of the tables (their table VI) the authors show their incidence of a false positive ECG diagnosis of a myocardial infarction. Five of the patients having an "infarct"-ECG were found to have a normal contraction pattern. Another difficulty is that as 77 of the patients had an "infarct"-ECG, the total percentage of false positive diagnoses should be $5 / 77$ patients 
$(6 \%)$. The authors claim, however, only $5 / 156$ patients $(3 \%)$. They are the only authors who have made observations about the "lateral" wall of the left ventricle. However, the numbers of patients studied are small. Because it is probable that most of these patients also had anterior wall infarction on the ECG, we have included them in the anterior infarct group.

Howard et al concluded that vectorcardiography is superior to the ECG in making the diagnosis of myocardial infarction.

\section{Study 3}

Mehta et al (26) were interested in vector and electrocardiographic changes and in ventriculographic abnormalities in isolated inferior wall infarction. They divided their 52 patients, all having an inferior wall infarction on the ECG, into 2 groups: 26 patients having an ejection fraction : $50 \%$, and 26 patients having an ejection fraction $\times 50 \%$. However, they did not discuss their criteria for an inferior wall infarction on the ECG. Of the 52 patients, $77 \%$ had asynergy in the inferior segment. Ten out of 52 patients ( $19 \%$ ) also had asynergy in the anterior segment. Of these 10 patients, 5 proved to have an anterior wall infarction on vectorcardiography. This last finding is in agreement with the previous study and it shows the limitations of the ECG, where cancellation of the electrical forces may conceal coexistent myocardial infarction.

Their conclusion was that vectorcardiography can be a valuable supplementary tool in the assessment of patients who apparently show only an isolated inferior infarction on the ECG.

\section{Study 4}

Hamby et al (27) studied 264 patients: 82 of them had an isolated inferior, 55 an isolated anterior, and 27 patients a combined inferior and anterior myocardial infarction on the ECG. All patients had coronary artery disease.

This and the following study of Mc Caughan (28) are the only two where no patients were excluded because of a certain electrocardiographic pattern or additional nonischemic cardiac abnormalities. Forty-two percent of the patients with a "normal"ECG had an abnormal contraction pattern, whereas only $6 \%$ of the patients with an "infarct"-ECG had normal wall motion.

Hamby et al correlated the hemodynamic data with the ECG. Their findings were that those patients showing an anterior infarction on their ECG had a higher mean left ventricular end-diastolic pressure ( $\left.\mathrm{P}_{\mathrm{ed}}^{\mathrm{lv}}\right)(17.2 \mathrm{mmHg})$ than patients with a "normal"-ECG $(12.5 \mathrm{mmHg})$. They concluded that the difference in degree of impairment of LV function probably reflects more extensive damage to the myocardium in anterior, than in inferior infarction.

They also studied the clinical and coronary angiographical findings in their patients. Because this is not the subject of our study, they will not be discussed here.

\section{Study 5}

Mc Caughan et al (28) studied the value of computer interpretation using the Frank lead system in patients with segmental wall motion abnormalities.

Of 107 patients with documented asynergy, 7 patients had a conduction disturbance on the ECG preventing the diagnosis of myocardial infarction. In $75 \%$ of the 
remaining 100 patients the ECG showed a myocardial infarction. In $65 / 75$ patients $(87 \%)$ the localization of abnormal segmental wall motion was in concordance with the ECG abnormalities. Infero-posterior infarctions on the ECG had the most signilicant degree of discrepancy with the ventriculographic "infarctions". The authors stress the high percentage of correct classification (91\%) using computer ECG interpretation. Detailed analysis of the tables in the article (their table II), however, shows that the actual percentage is much lower. First, it implicitly states that a correct diagnosis was made in patients having intraventricular conduction defects. The computer analysis of these ECGs, however, was "myocardial infarction, location not specified". Therefore, it is difficult to accept this subgroup of patients as being "correctly diagnosed". Second, one can question the computer diagnosis of left or right ventricular hypertrophy or nondiagnostic myocardial changes as pointing to myocardial infarction. One would tend to accept only the computer diagnosis: "myocardial infarction", which was made in 75 patients, as the correct one. Computer analysis then results in a $70 \%$ correct interpretation.

\section{Situdy 6}

Bodenheimer et al (29) studied 216 patients in order to assess the value of a pathological $\mathrm{O}$-wave in predicting the presence and severity of ventricular asynergy. Of the 216 patients studied, 21 had congestive cardiomyopathy. None of these patients had abnormal Q-waves, but in all patients severe asynergy of the left ventricle was found. In our tables II and III these 21 patients were excluded because insufficient data was available. The other 195 patients had coronary artery disease. Asynergy was present in $95 \%$ of cases showing pathological Q-waves. A strong correlation was found between the localization of the abnormality on the ECG, and the localization of asynergy on left ventriculography: for anterior wall infarctions in $29 / 30 \mathrm{pa}-$ tients $(97 \%)$, and for inferior wall infarction in $25 / 33$ patients $(76 \%)$.

They found, like Miller (24), that patients with anterior infarction on the ECG have more severe abnormalities of wall motion than patients with inferior infarction.

If $\mathrm{O}$-waves were present on the ECG, $72 \%$ of the asynergic zones exhibited akinesis or dyskinesis. In the absence of Q-waves an aneurysm was present in $15 \%$. In $5 / 52$ patients ( $10 \%$ ) having aneurysms, ST-segment elevation was present. A definition of ST-segment elevation was not given.

They also studied the relation between $\mathrm{P}_{\mathrm{ed}}^{\mathrm{W}}$ and the location of $\mathrm{Q}$-waves. Increased $P$ ed was found more often in patients with anterior wall infarctions. $P$ ed $+12 \mathrm{~mm} \mathrm{Hg}$ was present in $18 / 30$ patients with anterior infarction versus $7 / 33$ patients with inferior infarction. Not unexpectedly, the same holds for anterior (and apical) as compared to inferior asynergy. $\mathrm{P}$ ed, $12 \mathrm{mmHg}$ was found in $15 / 33$ patients with anterior asynergy versus $6 / 24$ patients with inferior asynergy. These findings are in agreement with those of Hambyet al (27).

\section{Study 7}

Young et al (30) also analysed the relationship between vector and electrocardiographic findings and LV asynergy. One hundred and two patients with coronary artery disease and asynergy of the anterior and apical segments were studied. In $89 /$ 102 patients ( $87 \%$ ), an "infarct"-ECG was diagnosed as present if poor R-wave and reversed R-wave progression were included as being in the group of "infarct"- 
ECGs. If pathologic Q-waves were used as the sole criterion accepted for diagnosing myocardial infarction, then $62 \%$ had an "infarct"-ECG. Diagnostic vectorcardiographic abnormalities were found in $84 \%$. These findings show that inclusion of QRS criteria other than pathologic Q-waves can improve the number of correct diagnoses.

\section{Study 8}

Willams et al (31) examined 225 patients for the relationship between the electrocardiographic diagnosis of transmural myocardial infarction and LV asynergy. All patients had electrocardiographic evidence of transmural myocardial infarction. Eighty-two patients had an anterior wall infarction, 100 patients an inferior wall infarction and 43 patients a combined inferior and anterior wall infarction. In $19 \%$ of patients with a myocardial infarction, a normal contraction pattern was present. mainly in patients with an inferior infarction. Of patients with an "infarct"-ECG located in one area, $58 / 182$ patients (32\%) showed an abnormal contraction pattern of the left ventricle also in other than the expected segments.

Williams et al also analysed the coronary abnormalities in relation to segmental wall motion on the ECG. For reasons given before, these findings will not be discussed.

\section{Study 9}

Arkin et al (32) studied the relation between the ECG and the pattern of LV wall motion using biplane ventriculography $\left(30^{\circ} \mathrm{RAO}\right.$ and $60^{\circ} \mathrm{LAO}$-projection). They also reviewed the literature on this subject and discussed the sensitivity, specificity and predictive accuracy of the correlation of "infarct"-ECGs and asynergy in the different studies.

We believe, however, that some of the numbers given in their table VI are invalid. This does not significantly affect the total number and percentage, or conclusions drawn.

In their study of 200 patients with coronary heart disease, Arkin et al found that in $74 / 116$ patients $(64 \%)$ having a "normal"-ECG, asynergy was present, whereas in only $6 / 84$ patients (7\%) with an "infarct" $-\mathrm{ECG}$, a normal contraction pattern was seen.

An important difference between this study and all other discussed studies wits that their method (CASS-method) of LV wall motion assessment was different. In contrast with the studies $1,4,6$, and 8 , it was not possible to separate patients having an isolated infarct from patients with infarctions in more areas (table III).

The authors endeavoured to find more sensitive criteria for posterior wall infarction on the ECG. Besides an R-wave $\geqslant 0.04 \mathrm{sec}$. in lead $V_{1}$, they used an $R / S$ ratio $\geqslant 1$ in leads $V_{1}$ and $V_{2}$, and an upright $T$-wave in lead $V_{1}$. Sensitivity, specificity, and predictive accuracy was highest when using the criterion $\mathrm{R}$-wave $\geqslant 0.04 \mathrm{sec}$. in lead $\mathrm{V}_{1}(51 \%, 98 \%$, and $80 \%$, respectively).

A correlation was drawn between the "infarct"-ECG and different degrees of asynergy. Like Miller (24) and Bodenheimer (29). Arkin showed that anterior asynergy was generally more severe than inferior asynergy. In discussing the value of biplane versus monoplane left ventriculography, they found that in $22 / 152$ patients $(14 \%)$ a greater asynergy was present in the LAO, than the RAO-projection. In only $4 / 152$ patients $(3 \%)$ asynergy was found only in the LAO-projection. The $60^{\circ}$ 
LAO-projection showed in $30 \%$ asynergy in the infero-posterior area, and in $17 \%$ asynergy in the antero-septal area.

\section{Conclusions from the 9 studies (24-32)}

By combining all data available from the 9 studies, the following analysis can be made: Of the 1424 patients studied, 1134 had asynergy. Nine hundred and seven of these patients had an "infarct"-ECG, of which 348 were located in the anterior wall, 370 in the inferior, and 20 in the posterior wall (table II). Ninety-four patients had multiple infarctions as shown on the ECG. In study number 5 no data on infarct localization on the ECG was given. Some data represented in tables II and III is incomplete, or shows a selected group of patients. For example, in studies 2, 5, and 7, only patients with asynergy were studied, while in studies 3 and 8 all ECGs showed myocardial infarction (table I).

\section{Table IV.}

Correlation between the presence or absence of an "Infarct"-ECG and lefi ventricular wall motion. Results from 9 studies $(24-32)$

\begin{tabular}{|c|c|c|c|c|}
\hline & & $\begin{array}{l}\text { Number } \\
\text { of srudies }\end{array}$ & $N$ & $\%$ \\
\hline "Infaret"- $\mathrm{ECO}$ & Total & 5 & $364 / 618$ & 59 \\
\hline \multirow[t]{3}{*}{ Asynergy } & Anterior & 2 & $64 / 156$ & 41 \\
\hline & Inferior & 2 & $86 / 183$ & 47 \\
\hline & Posterior & 2 & $17 / 107$ & 16 \\
\hline "Normal"'-ECG & Total & 3 & $150 / 163$ & 92 \\
\hline \multirow[t]{3}{*}{ Synergy } & Anterior & 2 & $157 / 158$ & 99 \\
\hline & Inferior & 2 & $162 / 173$ & 94 \\
\hline & Posterior & 1 & $83 / 87$ & 95 \\
\hline Asynergy & Total & 7 & $661 / 743$ & 89 \\
\hline \multirow[t]{4}{*}{ "Anfartet" } & Anterior & 5 & $208 / 228$ & 91 \\
\hline & Interior & 6 & $293 / 343$ & 85 \\
\hline & Postenior & 2 & $10 / 11$ & 91 \\
\hline & Combinations & 3 & $32 / 32$ & 100 \\
\hline Asynergy correspondling seyments & Total & 6 & $465 / 582$ & 80 \\
\hline \multirow[t]{3}{*}{ "Infarct"-ECG } & Anterior & 5 & $228 / 251$ & 91 \\
\hline & Inferior & 6 & $248 / 339$ & 73 \\
\hline & Posterior & 2 & $14 / 20$ & 70 \\
\hline Asynergy in other than & Total & 3 & $101 / 371$ & 27 \\
\hline corresponding segment & Anterior & 2 & $43 / 137$ & 31 \\
\hline "Infaret"-ECG & Inferior & 2 & $48 / 182$ & 26 \\
\hline Asynergy & Total & 4 & $182 / 393$ & 46 \\
\hline \multirow[t]{2}{*}{ "Normal"-ECG } & Anterior & $i$ & $32 / 100$ & 32 \\
\hline & Inferior & 1 & $12 / 100$ & 12 \\
\hline
\end{tabular}


Of the 618 patients having asynergy, $59 \%$ had an "infarct"-ECG ( 5 studies) (table IV). Sixty-four of the 156 patients ( $41 \%$ ) with asynergy in the anterior segment had an anterior "infarct"-ECG, 86/183 patients ( $47 \%$ ) with asynergy in the inferior segment had an inferior "infarct"-ECG, and $17 / 107$ patients $(16 \%)$ with asynergy in the posterior segment proved to have a posterior "infarct"-ECG.

Ninety-two percent of patients with a normal contraction pattern of the left ventricle had a "normal"-ECG ( 3 studies). When subdivided into different electrocardiographic lead groups, the anterior leads were normal in $99 \%$ (2 studies), the inferior leads in $94 \%$ ( 2 studies), and the posterior leads in $95 \%$ ( 1 study).

In patients having an "infarct"-ECG, $89 \%$ had asynergy in one or more segments ( 7 studies). Asynergy in the anterior segment was present in $91 \%$ of the patients showing an anterior wal infarction on the $\mathrm{ECG}$, in $85 \%$ there was asynergy of the inferior segment in the presence of an inferior infarction. Ninety-one percent had posterior asynergy in posterior infarction. Asynergy was present at two sites in $100 \%$, if the ECG showed several infarctions.

Patients having an "infarct"-ECG proved to have asynergy in $80 \%$ in the corresponding segment. This was the case in $91 \%$ of patients having an anterior wall infarction, in $73 \%$ with an inferior infarction, and in $70 \%$ with a posterior infarction. In $27 \%$ of the "infarct"-ECG patients, asynergy was also present in other than the corresponding segment (3 studies); anterior "infarct"-ECG: 31\%; inferior "infarct"'-ECG: $26 \%$.

Of those patients having a "normal"-ECG, $46 \%$ showed asynergy ( 4 studies), $32 \%$ in the anterior wall and $12 \%$ in the inferior wall (only one study).

In discussing the results of these studies, Arkin (32) noted that important differences between these studies existed. He explained them by observing that:

\section{The criteria for asynergy varied from study to study.}

Because of these differences in criteria, values for sensitivity of Q-waves in the anterior chest leads on the ECG in diagnosing LV asynergy varied from 36 to $55 \%$. Qwaves in the inferior leads had a sensitivity for diagnosing LV asynergy ranging from 35 to $75 \%$.

Arkin showed that these changes in sensitivity, specificity, and predictive accuracy are greatest in patients with inferior and true posterior myocardial infarctions.

The electrocardiographic pattern of anterior myocardial infarction is, in general, accompanied by a higher degree of asynergy. Therefore, this group is less affected by changes in criteria for asynergy.

2. Some studies have correlated the electrocardiographic changes with asynergy in corresponding regions, while others have not specified anatomically the area of asynergy correlated with the supposed site of the electrocardiographic changes.

3. In all but two studies, single-plane $\mathrm{RAO}$-projection of the left ventriculography was performed. This precludes any appreciation of asynergy of the septum and posterior wall, which can only be judged in the LAO-projection.

4. The more stringent the criteria for electrocardiographic changes, the lower the sensitivity, and the higher the predictive accuracy of the ECG.

5. Some series included patients whose ECGs showed bundle branch block, con- 
duction abnormalities, or hypertrophy patterns, which obviously impair correlation possibilities.

In reviewing the different series, some additional comments can be made:

- Arkin did not consider the effect upon the results of the application of the different methods used to evaluate $\mathrm{LV}$ wall motion.

- Most studies do not accurately describe the precise localization of the LV segments.

- No weighting was given to inaccuracies in measurements of LV end-diastolic and end-systolic contours.

- Other studies have shown that segmental wall motion abnormalities are not absolute. Segmental wall motion can improve after ventricular premature contractions or the administration of nitroglycerine even in the presence of $Q$-waves in the corresponding ECG leads (36-38). In some cases atrial pacing can induce asynergy ( 39 , 40). Changes in segmental wall motion can also occur after coronary bypass surgery (41).

Others endeavoured to define the value of the ECG for predicting $L V$ function by comparing ECG findings with other methods of study of LV wall motion.

Palmeri et al (42) used a scoring system based on the duration of $\mathrm{Q}$ - and R-waves, and on the ratios of R-to-Q and R-to-S amplitude. A scoring list was made by giving points in the presence of one or more of these criteria. For example, a $\mathrm{Q}$-wave in lead I was 2 points, and a $\mathrm{Q}$-wave in lead $V_{1}$ was 4 points.

The ECG score was compared with a radionuclide-determined LV ejection fraction and wall motion of the anterior and inferior wall. They found that a score, 3 had a $93 \%$ sensitivity and a $88 \%$ specificity for both severe regional asynergy and major depression of global LV ejection fraction. An important problem in this study is that no description is given of their grading system of segmental wall motion. Interestingly, in this study the appreciation of a $Q$-wave in lead $V_{1}$ was high, leading to a maximal score of 4 points. Because of the findings in our own study, we have some doubts about this criterion. A significant conclusion of the article was, that the more Q-waves were present on the 12-lead ECG, the more severe the impairment of LV function. In normal wall motion, the QRS-score had a mean of 0.9 ; in hypokinesis 1.2 ; akinesis 6.6 ; and dyskinesis 8.2 .

\section{Lefiventricular wall motion in left bundle branch block}

In most studies, patients with left bundle branch block were excluded. This is, however, an interesting and important group because patients with left bundle branch block demonstrate a high incidence of an impaired contraction pattern of the left ventricle.

Dabizzi et al (43) reported 34 patients with left bundle branch block and coronary artery disease. They found that only $2 / 34$ patients had a normal contraction pattern. The abnormal wall motion was, in most cases, located in the anterior wall. Left axis deviation, in the presence of left bundle branch block, had no influence on the degree of severity of the findings. 
Williams et al (44) studied 15 patients with left bundle branch block without coronary artery disease and found severe asynergy in most patients $(83 \%)$. The wall motion abnormalities were not restricted to one area, but found in all segments. In this study, no distinction was made between patients with normal and left axis deviation.

\section{b. Left ventricular wall motion assessment}

Chaitman et al (45) studied reproducibility of the analysis of segmental wall motion of the left ventricle. A comparison was made between the objective and subjective analysis of the LV wall motion by one or wo observers. Objective analysis was done by calculations from tracings of end-diastolic and end-systolic frames. Subjective evaluation was done by two experienced observers by visual inspection.

Objective analysis, repeated by the same observer, showed that only 1 out of the 105 segments was identified differently. Four classes of wall motion were possible: normal, hypokinetic, akinetic, and dyskinetic. A second observer clisagreed in $8 \%$ of the cases. A wide variability was present when subjective observations were made. Repeated assessment by the same observer showed a difference in $19 \%$ of segments. If it was done by two independent observers, disagreement was found in $27 \%$ of segments. No significant variability resulted from selection of different beats. Their conclusion was that the major source of variability arose from tracing the silhouettes.

Measurements of LV-volume proved to have a much better correlation: LV enddiastolic volume, LV end-systolic volume, and ejection fraction had correlations of $r=0.98 ; 0.99 ;$ and 0.99 , respectively, if objective analysis was done by oneand the same observer. Correlation coefficients from determinations, performed by two objective observers, were: $r=0.93 ; 0.98$; and 0.95 , respectively. If subjective. (visual) analysis was done by two observers, results were less good: end-diastolic volume $r=0.64$, and ejection fraction $r=0.84$.

Kuyer (46) analysed end-systolic and end-diastolic volume by the areawength method using biplane left ventriculography (PA-projection and lateral-projection). For end-systolic volume the differences between 2 measurements of the same beat were $17 \%$, and for end-diastolic volume $7 \%(r=0.98)$

He also measured 3 consecutive beats during sinus rhythm. Differences between the values for end-systolic and end-diastolic volume of these 3 beats were minimal. These results are in agreement with those of Chaitmanet al (45).

Hammermeister et al (47) found that LV end-diastolic and end-systolic volumes, measured over 3 to 5 cardiac cycles, showed no significant changes.

Rogers et al (48) assessed end-diastolic volume, end-systolic volume, and ejection fraction with biplane techmique in RAO and LAO-projections. Whan objective measurements were performed by two independent observers, they found comrelation coefficients of $0.98 ; 0.99$; and 0.94 , respectively. 
Effect of contrast on left ventricular performance

In comparing the data from the different series, it is of importance to realize that, besides left ventriculography, most patients also had coronary arteriography. In some studies coronary angiography was done first, in others left ventriculography.

The effect of angiocardiographic contrast on LV performance has been studied. Levinson (49) showed, in dogs, a decrease in LV end-diastolic and end-systolic dimensions. This appeared immediately after injection, and in all instances remained present for at least 12 beats.

Rahimtoola (50) assessed, in 22 patients, ventricular performance before and after ventriculography. He found an increase in circulating blood volume with an unchanged afterload. Patients with a normal left ventricle responded with an increase in work performance. However, patients with serious heart disease had a decrease in work performance.

Friesinger et al (51) found a decrease in afterload because of a fall in peripheral arterial pressure. They found simular effects on LV performance. The effect on hemodynamic parameters was maximal 1 minute after injection. $P_{\mathrm{ed}} \mathrm{v}_{\mathrm{V}}$ stabilizes after 9 minutes, but remains higher than before injection of the contrast materiall.

All these observations indicate that comparison of results from different studies may be difficult and should be made with reservation.

\section{Left ventricular wall motion assessment}

For our study adequate assessment of $\mathrm{LV}$ wall motion is essential. The four commonly used methods in the literature are:

Method 1: Herman et al (17), shown in figure 1.

Method 2 : Leighton et al (52), shown in figure 2.

Method 3 : Harris et al (53), shown in figure 3.

Method 4 : Rickards et al (54), shown in figure 4.

Other methods of assessment of the LV wall motion have been described, but they will not be discussed ( $55-58)$. 
Figure 1 shows the method of Herman at al (17). The long axis between the aortic walve centric point and the apex is determined. The long axis of the end-systolic frame is shifted and rotated, resulting in superimposing the end-diastolic long axis, where both midpoints of the lines are identical. The long axis of the end-diastolic frame is intersected by perpendiculars at $25 \%$ intervals. Shortening of the left ventricle is measured along these perpendiculars and the long axis. Solid lines $=$ end-diastolic silhovette. Dashed $1 \mathrm{i}$ nes $=$ end-systolic sillowette.

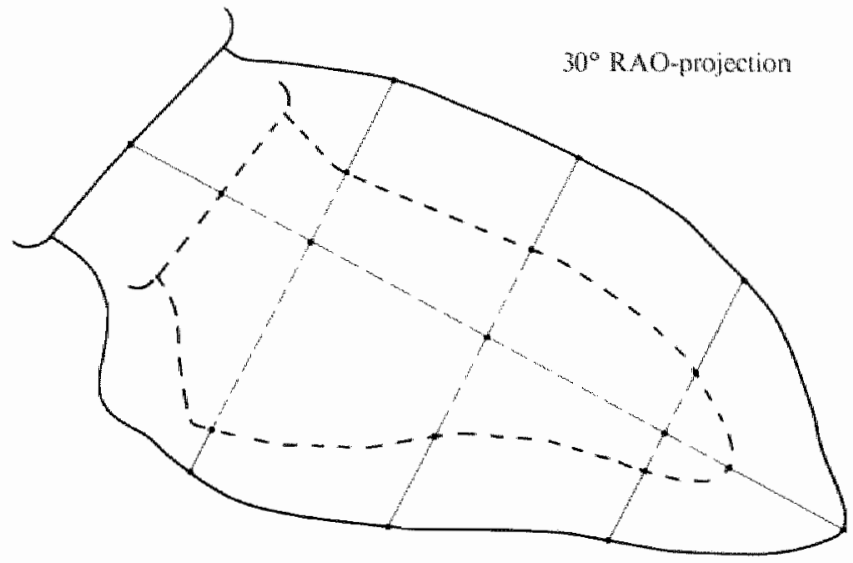

Figure 2 shows the method of Leighton et al (52). The long axis was determined from the apex to the intersection of the aortic valve plane, as an indexing line which bisects the $L V$ aren at end-systole and enddiastole. The end-systolic and end-diastolic long axis are superimposed by rotation, and the LV silhouettes are retraced. Then the end-systolic line is divided into five equal segments by four perpendiculars to the long axis. Shortening of the left ventricle is measured along these perpendiculars and the long axis. Key as in figure 1 .

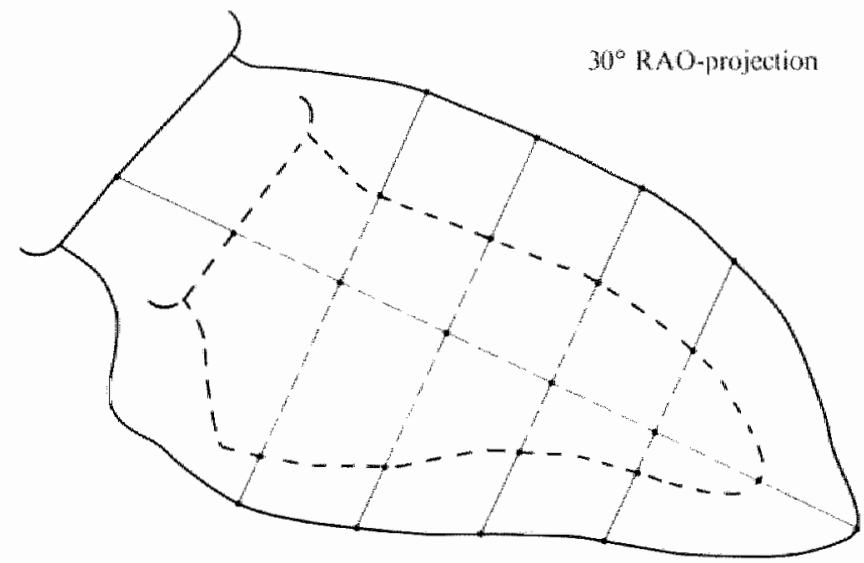


Figure 3 shows the method of Harris et al ( 33 ). Shortening of the left ventricle is measured at a constant polat angle from the origin at the midpoint of the long axis between the apex and the center of the aortic walve. The long axis of the end-systolic frame is shifted and rotated, resulting in superposition of the end" systolic and end diastiolic longatis, where the mid point of both lines is identical. Key as in figure 1 .

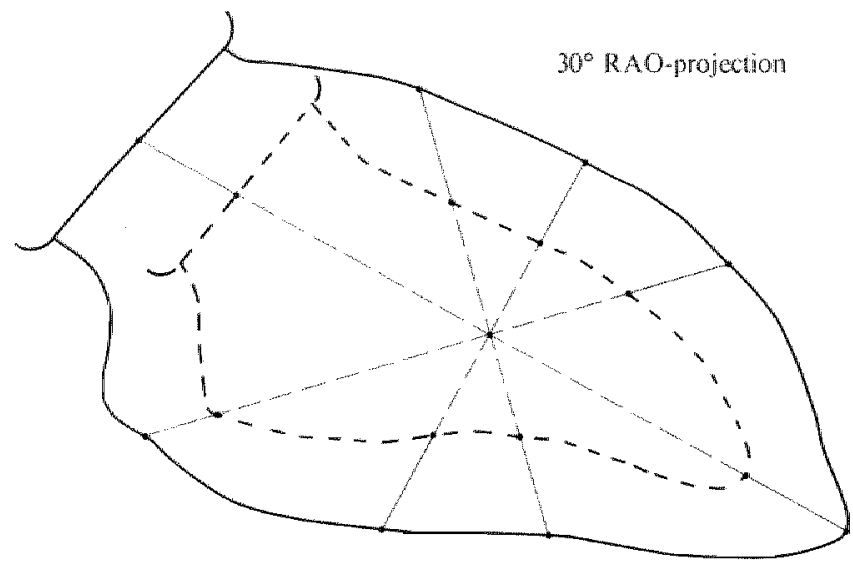

Figure 4 shows the method of Rickards et all (54). The end-systolic and end-diastolic frames are shifted and rotated, resulting in a superimposed artic valve line, where the centric point of both aortic valve lines are identical. A geometric center of gravity is then determined and used as the midpoint. From this midpoint, shortening of the left ventricle is measured at constant polar angles. Key as in figure 1.

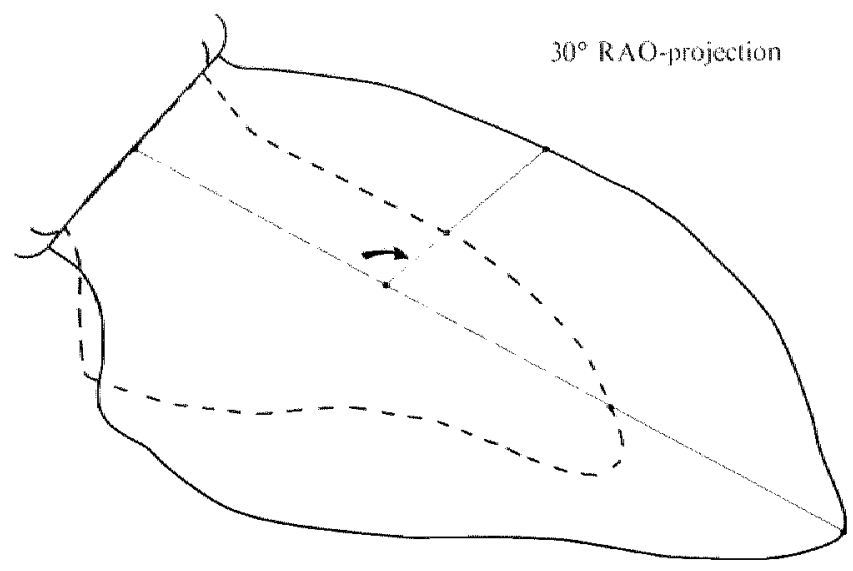




\section{Method 5}

The Stanford group added a fifth method $(1,59-64)$. They used a point at $69 \%$ on the line that can be drawn in the RAO-image between the projected antero-lateral aortic valve edge and the apex, in combination with a polar co-ordinate system. The most important difference between the Stanford method and the four others is the reference system to correct the movement of the maximal diastolic LV contour in regard to the maximal systolic LV contour. In contrast to methods 1 to 4 , method 5 uses an external reference system. This reference system is not coupled to the motion of the heart, but to external markers. The diaphragm can be used to exclude respiratory movements. Edlges of lead shutters, ribs, or external chest wall markers, are used to make sure that the patient's chest has not moved during filming. All the other four methods use a reference system which is coupled to specific identifiable points within the heart, as the apex of the heart, or valvular edges. The Stanford method is shown in figure 5 .

Figure 5 shows that shortening of the left ventricle is measured at polar angles from an origin fixed at a point $69 \%$ of the distance from the aortic valve edge to the apex, at end-systole. Key ats in figure 1.

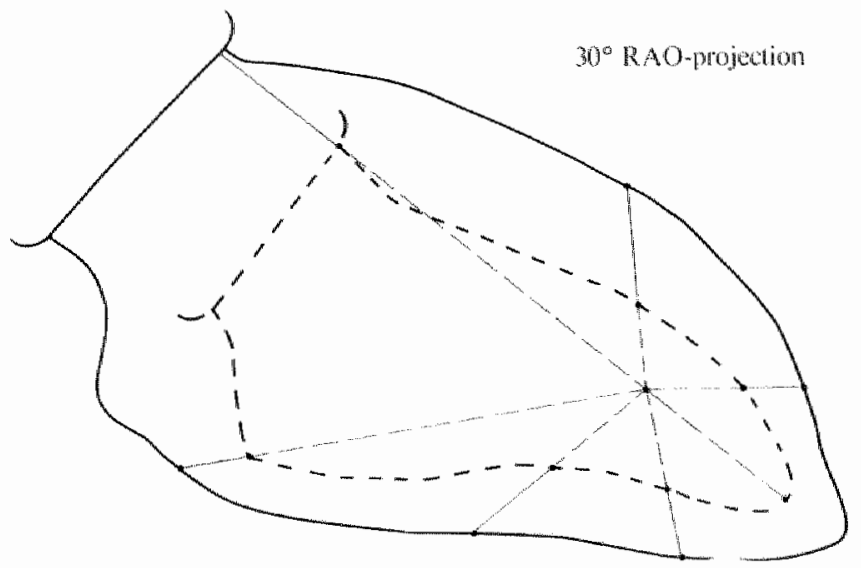

According to Ingels, the errors between methods 1 to 4 are not significantly different, showing that use of different co-ordinate systems, like rectangular or polar coordinates, have only a small influence. Also the indexing system, which is the system to realign or superimpose images of the end-systolic and end-diastolic frame, is of minor intluence (table $\mathrm{V}$ ). 
Table V.

Characteristics of five different methods used to study left ventricular wall motion

\begin{tabular}{|c|c|c|c|}
\hline Method & $\begin{array}{c}\text { Conordinate } \\
\text { syurem }\end{array}$ & $\begin{array}{c}\text { Reference } \\
\text { system }\end{array}$ & Imdexing system \\
\hline 1. Homanet al (17) & Rectangular & Internal & $\begin{array}{l}\text { Frame-by-frame } \\
\text { Transiation/rotation } \\
\text { Aortic valve midpoint } \\
\text { Apex } \\
\text { Long axis midpoint }\end{array}$ \\
\hline 2. Leighton et al.(52) & Rectangular & Internal & $\begin{array}{l}\text { Frame-by-frame } \\
\text { Rotation } \\
\text { Apex } \\
\text { Long axis } \\
\text { Bisecting left vencricle }\end{array}$ \\
\hline 3. Harrisetal. (53) & Polar & Internal & $\begin{array}{l}\text { Frame-by-frame } \\
\text { Translation/rotation } \\
\text { Aortic valve midpoint } \\
\text { Apex } \\
\text { Long axis midpoint }\end{array}$ \\
\hline 4. Rickards ctal.(54) & Polar & Internal & $\begin{array}{l}\text { Frame-by-frame } \\
\text { Translation/rotation } \\
\text { Aortic valve midpoint } \\
\text { End-systolic center of area }\end{array}$ \\
\hline 5. Ingels et al, (1) & Polar & External & $\begin{array}{l}\text { Fixed: End-systolic } \\
\text { Aortic valve } \\
\text { Apex }\end{array}$ \\
\hline
\end{tabular}

The Stanford group has attempted to study the reliability of the five methods of quantitative assessment of ventricular wall motion shown in table $\mathrm{V}$. Like others (65-69), they used metal markers. Theoretically, the best approach would be implantation of endocardial markers. This has been performed in dogs (68) and pigs (69). This method is not practised in humans because of the high risks. Therefore, epicardial clips have been chosen (65-67). This has contributed to better knowledge of LV wall motion. The Stanford group used the following approach: during cardiac surgery, 7 radiopague tantalum markers were implanted into the LV midwall in 58 patients. These markers were placed in such a way that they silhouetted the LV wall in the $30^{\circ}$ RAO-projection $(1,59-64)$. 


\section{Mid wall motion}

The measurement accuracy of the five methods in table IV, for assessment of wall motion in $30^{\circ}$ RAO-projection, was evaluated by comparing marker motion (1).

A significant difference between errors made by the Stanford method, and the four others, was demonstrated (table VI). The best correlation between real marker motion and one of the 5 methods was observed using method 5 , irrespective of wall segment location.

Table VI.

Comparison of real marker motion by application of the 5 methods for assessment of wall motion $(1,17$, $52-54)$

\begin{tabular}{llllll}
\hline & $\begin{array}{l}\text { Method } \\
(\text { Herman })\end{array}$ & $\begin{array}{l}\text { Method2 } \\
\text { (Leighton) }\end{array}$ & $\begin{array}{l}\text { Method3 } \\
\text { (Harris) }\end{array}$ & $\begin{array}{l}\text { Mehod } 4 \\
\text { (Rickards) }\end{array}$ & $\begin{array}{l}\text { Methods } \\
\text { (Sranford) }\end{array}$ \\
\hline Error: & $47.5 \%$ & $42.5 \%$ & $44.0 \%$ & $46.2 \%$ & $25.9 \%$ \\
\hline
\end{tabular}

\section{Endocardial wall motion}

A comparison of marker motion with the estimated ventriculographic border motion, using each of the five methods, proved that the Stanford method was superior for all sites; the anterior, the apical, as well as the inferior area (table VII).

Table VII.

Regression analysis of ventriculographic border motion $(x)$ versus the real marker motion $(y)(1,17,52-$ 54)

\begin{tabular}{llllll}
\hline & $\begin{array}{l}\text { Method) } \\
\text { (Herman) }\end{array}$ & $\begin{array}{l}\text { Method2 } \\
\text { (Leighon) }\end{array}$ & $\begin{array}{l}\text { Method3 } \\
\text { (Harris) }\end{array}$ & $\begin{array}{l}\text { Method } \\
\text { (Rickards) }\end{array}$ & $\begin{array}{l}\text { Method5 } \\
\text { (Stantford) }\end{array}$ \\
\hline All sites: & & & & & \\
r & 0.49 & 0.22 & 0.59 & 0.33 & 0.68 \\
slope & 1.11 & 1.43 & 1.33 & 1.59 & 1.48 \\
SEE & 0.40 & 0.61 & 0.42 & 0.90 & 0.46
\end{tabular}

Abbreviations: $r=$ correlation coefficient; Sllope $=$ slope of regression line $(y / x) ;$ SEE $=$ Standard error of the estimate.

Although their method was most accurate, Ingels et al stated that myocardial dynamics cannot be measured with precision from contrast angiograms using any combination of reference and co-ordinate systems. The most plausible explanation for this is the artifact caused by trabeculation and papillary muscle exclusion of dye. This results in uncoupling of contrast border motion from wall motion in an unpredictable way $(70,71)$. Other sources of errors will be discussed in the next chapter. 
Using the Stanford method, several important observations have to be mentioned: The proportional error was dependent upon the distance to the $69 \%$ point. The minimum error found was $25.9 \%$ close to the $69 \%$ point. The maximum error was $37.5 \%$ near the antero-lateral edge of the aortic valve (figure 6 ).

Figure 6 shows the end-diastolic and end-systolic positions of intramyocardial markers and endocardiun. The minimum error is $25.9 \%$ close to the $69 \%$ point. The maximum error is $37.5 \%$ near the antero-laterat edge of the aortic valve. Choice of a fixed external reference system with polar origin at the $50 \%$ point on the line from mid-artic walve to apex would result in an increase of error of $2.1 \%$. Dashed fines $=$ end-diastolic sithouet te. Solid lines = end-systohic silhouette (1).

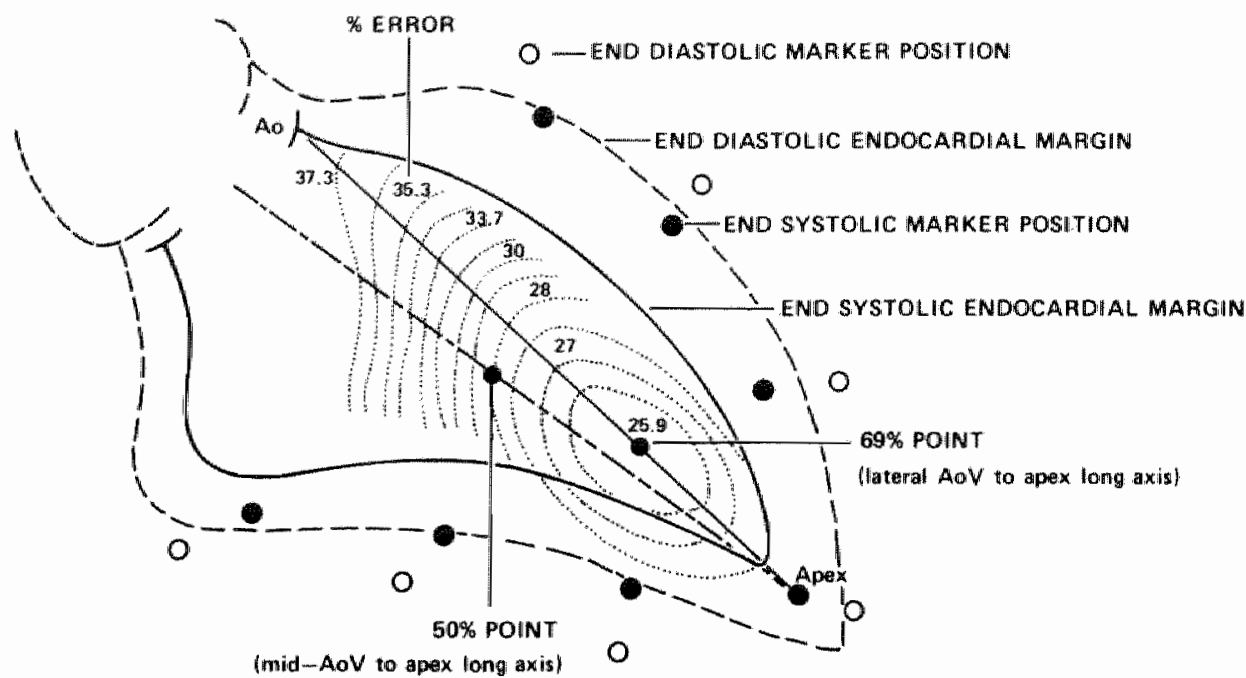

Although the $69 \%$ point represents the optimal position (minimum error), the selection of another point, such as the $50 \%$ point of a ventricular long axis (figure 6), increases the error by only $2.1 \%$. Frame-by-frame reindexing of this midpoint (as in method 3 ) yields an error of $44,0 \%$, a 1.6 fault increase in error.

Thus the bulk of the error reduction, applying method 5, was due to the use of a fixed external reference system, with a small additional decrement of error by proper selection of the polar origin.

The analysis of Ingels et al suggests that this is the best method presently available. It made us decide to use method 5 as the most accurate approach to assess $L V$ wall motion. 


\section{Chapter 3}

\section{Material and methods}

\section{a. Patients}

Three hundred and three patients were studied. All underwent cardiac catheterization for different reasons and were admitted between April 1977 and October 1981 to the Department of Cardiology of the Annadal Hospital Maastricht, The Netherlands. The series is not consecutive because patients were accepted only if the left ventriculogram and the ECG were of optimal quality. As of January 1, 1980, only patients with coronary artery disease were included in the study. Table VIII gives data on age and sex. As expected, it shows a preponderance of males in all age groups.

Table VIII.

The distribution of age and sex of the 303 patients studied

\begin{tabular}{lccccccccc}
\hline age & $10-20$ & $20-29$ & $30-30$ & $40-49$ & $50-59$ & $60-69$ & $70-79$ & Toul & Meanage \\
\hline male & 1 & 5 & 27 & 85 & 78 & 39 & 2 & 237 & 50.1 \\
temale & 1 & 4 & 17 & 26 & 17 & 1 & 66 & 53.0 \\
Total & 1 & 6 & 31 & 102 & 104 & 56 & 3 & 303 & 50.7 \\
\hline
\end{tabular}

The final diagnosis was made after cardiac catheterization, and in some patients after an additional electrophysiological study.

The diagnosis myocardial infarction was based upon electrocardiographic documentation of the development of an acute myocardial infarction combined with the clinical picture and characteristic enzyme changes.

One patient had cleavage of a myocardial bridge over the left anterior descending coronary artery because of symptomatic cardiac ischemia. Following this procedure, recatheterization was performed. The left ventriculography showed a circumscript aneurysm in the anterior wall. 
In table IX the clinical diagnosis of the 303 patients studied is summarized.

\section{Table IX.}

The clinical dianosis of the 303 patients studied

A. Coromary artery distease

Woprevious myocardial infarction

Provious myonardial infaration

History but mo prool of myocardial infarction

Additional diagnowis in the 218 paters with coromary artery disease

Valvelar heart disease

Mitral incompetence

GradeI

Gradell

Grade llu

6

Corde iv

Aortic stenosis

\section{Cardiac Arrhythmias}

Pirevious cardiac surgery

Coronary bypass surgery

Coronary bypass surgery + aneurysmectomy

Coromaty bypass surgery + motral valve replacement

B. Atypical chest pain no abnormalities found

prolapse mitral valve

pericarditis

2

C. Cardlomyopathy congestive

obstructive

\section{6}

1

D. Conuential heart disease

Atribl soptal defect

Anomalouscononary artery

E. Acquired valve disease

mortic valve

7. Arrhythmias(non cononary disease) 
Hypertension was known to be present in 72 patients.

Clinical data, the observations on segmental wall motion, the hemodynamic data, and the electrocardiographic interpretations of all patients, were fed into a Digital VAX $11 / 780$ computer, using the statistical packages SPSS (72).

\section{b. The electrocardiogram}

In all 303 patients a resting ECG was recorded on the day of the catheterization before the investigation took place. In none of these patients was chest pain present at the time of recording the ECG. Our patient group included some patients whose infarctions occurred more than 15 years before the cardiac catheterization. This provides an explanation as to why, in these patients, there was poor electrocardiographic documentation of the episode during myocardial infarction. Infarct size often was unclear because of infrequent determinations of enzyme levels. In some of our patients, myocardial infarction could have occurred without the typical history or electrocardiographic or enzymatic documentation. According to our criteria they were not included in the group of patients with documented previous infarction. In patients with a previously documented myocardial infarction, the time between infarction and the ECG used for this study, was at least 3 weeks. A number of patients with negative T-waves in the precordial leads had emergency cardiac catheterization because of suspicion of an impending extensive anterior wall infarction. A few of these patients had small enzyme rises ( $S G O T \leqslant 2 x$ normal value) one day to one week before catheterization.

None of the patients suffered a myocardial infarction between the time of registrat tion of the ECG and the end of the cardiac catheterization. The ECGs were registered using either a Siemens-Elema Mingograf 6-channel recorder or a Marquette 4000 3-channel recorder.

The ECGs were interpreted using the following criteria:

$\begin{array}{ll}\text { 1. Frontal plane electrical axis } & - \text { right }:>+90^{\circ} \\ & - \text { normal }: \geqslant-30^{\circ} \mathrm{to} \leqslant+90^{\circ} \\ & - \text { left }:<-30^{\circ} \\ & - \text { indetermined }\end{array}$

2. Width of the QRS-complex $\quad-<0.12 \mathrm{sec}$.

$-\geqslant 0.12 \mathrm{sec}$.

In patients having a QRS-width $\geqslant 0.12 \mathrm{sec}$, differentiation was made into right bundle branch block, left bundle branch block, or atypical bundle branch block.

\section{Low Voltage}

This diagnosis was made if the total height of the QRS-complex was $\leqslant 5 \mathrm{~mm}$ in all extremity leads, and $\leqslant 7 \mathrm{~mm}$ in the precordial leads. 


\section{Q-wave}

The diagnosis of a pathological $\mathrm{Q}$-wave required:

Q-width $\geqslant 0.04 \mathrm{sec}$.

and or a $\mathrm{Q}$-wave voltage $>25 \%$ of the $\mathrm{R}$-wave

or a QS-complex.

The total width of the pathological Q-wave or QS-complex was not measured.

\section{R/Sratio}

An $R / S$ ratio $\geqslant 1$ in leads $V_{1}$ and $V_{2}$

\section{Decrease of $R$-wave voltage in the precordial leads}

Going from lead $V_{1}$ to lead $V_{2}$ lead $V_{2}$ to lead $V_{3}$ lead $V_{3}$ to lead $V_{4}$

This criterion was only considered to be positive if the $R / S$ ratio was less than 1 in leads $\mathrm{V}_{1}$ to $\mathrm{V}_{4}$.

\section{Notching of the QRS-complex}

"This was defined as a dip of $\geqslant 1 / 2 \mathrm{~mm}$ in the ascending or descending portion of the QRS-complex.

Notching was not diagnosed when the dip was localized on the top of the $\mathrm{R}$, or the bottom of the S-wave, or touched the baseline.

\section{ST-segment elevation}

Required a take-off of the ST-segment $\geqslant 1 / 4 \mathrm{~mm}$ above the baseline, combined with a convex upward (domeshaped) ST-segment.

\section{ST-segment depression}

Required a take-off of the ST-segment $\geqslant 1 \mathrm{~mm}$ below the baseline or the presence of ST segment depression $0.08 \mathrm{sec}$. after the j-point.

\section{Negative T-wave}

This was defined as a T-wave with a minimal negativity of at least $1 \mathrm{~mm}$ under the baseline.

\section{Positive T-wave in $V_{1}$}

This criterion required a completely positive T-wave. It was only diagnosed when the $\mathrm{R} / \mathrm{S}$-ratio in lead $\mathrm{V}_{1}$ or $\mathrm{V}_{2}$ was $\geqslant 1$.

The ECGs were interpreted independently by two cardiologists. Using the defined criteria, there was complete agreement in the interpretation.

In table X and XI cumulative data of the ECGs are given. In table XI patients having wide QRS-complexes ( $\geqslant 0.12 \mathrm{sec}$.) are excluded. Note that lead AVR is not used in our study. Patients with right or left ventricular hypertrophy were included in the study. 
Table X.

Cumulative data of the 303 ECGs

1. Frontal plane electrical axis

Right axis deviation

6

Normal axis 260

Left axis deviation: $\quad 29$

Undetermined 8

2. Width of the QRS complex

QRS - width : $<0.12 \mathrm{sec}$.

280

QRS - width $: \geqslant 0.12 \mathrm{sec}$.

Wide QRS-complexes ( $\geqslant 0.12 \mathrm{sec}$.

CRBBB

CLBBB

atypical bundle branch block

5

3. Low voltage

Present. 22

Absent 281

Abbreviations: $\mathrm{CRBBB}=$ complete right bundle branch block, $\mathrm{CLBBB}=$ complete left bundle branch block. 
Cummulative data of the ECG fundings in II leads in the absence of wide QRS-Complexes $(N=280)$

\begin{tabular}{|c|c|c|c|c|c|c|c|c|c|c|c|}
\hline & Lead & II & HI & $A V L$ & $A V F$ & $v_{j}$ & $V_{2}$ & $v_{3}$ & $V_{4}$ & $V_{5}$ & $v_{6}$ \\
\hline O-wave & 21 & 29 & 76 & 42 & 49 & 38 & 38 & 40 & 28 & 15 & 9 \\
\hline RSratio $\geqslant 1$ & & & & & & 13 & 50 & & & & \\
\hline Loss of R-mave & & & & & & & 19 & 19 & 8 & & \\
\hline $\begin{array}{l}\text { Notching } \\
\text { ascending limb }\end{array}$ & - & - & 5 & - & 1 & $\mathbb{1}$ & 1 & 3 & 1 & 2 & - \\
\hline $\begin{array}{l}\text { Notching } \\
\text { desconding limb }\end{array}$ & - & 2 & 1 & - & 5 & - & 4 & 4 & 3 & 3 & $\mathbb{1}$ \\
\hline $\begin{array}{l}\text { STrsegment } \\
\text { devation }\end{array}$ & 11 & 6 & 24 & 10 & 17 & 30 & 30 & 35 & 28 & 15 & 6 \\
\hline $\begin{array}{l}\text { ST-segment } \\
\text { depression j-point }\end{array}$ & 5 & 4 & 1 & 2 & 2 & . & 2 & 9 & 18 & 18 & 14 \\
\hline $\begin{array}{l}\text { \$T-segment } \\
\text { depression } 0.08 \mathrm{sec} \text {. } \\
\text { after j-point }\end{array}$ & 11 & 9 & 3 & 5 & 4 & 2 & 2 & 10 & $\llbracket 9$ & 18 & 19 \\
\hline Negative $T$-wave & 25 & 18 & 53 & 51 & 27 & 56 & 32 & 43 & 52 & 40 & 39 \\
\hline $\begin{array}{l}\text { Positive } T \text { wave } \\
\text { if } R / S V_{1} \text { or } V_{2} \geqslant 1\end{array}$ & & & & & & 22 & & & & & \\
\hline
\end{tabular}

\section{c. Cardiac catheterization}

\section{Procedure}

All patients were studied after an overnight fast. Two and a half $\mathrm{mg}$ droperidol, and $0.05 \mathrm{mg}$ fentanyl intramuscularly, or $10 \mathrm{mg}$ diazepam orally, was used as premedication. All medication they were receiving at the time of catheterization was continued, with the exception of oral anticoagulant therapy.

After local anaesthesia with $5 \mathrm{cc}$ lidocain $2 \%$, a French 8 Cordis pigtail catheter was percutaneously introduced into a femoral artery using the Seldinger technique.

\section{Hemodynamics}

LV pressures were recorded using an HP-Statham transducer P23ID, and an HP 8805 amplifier.

Leads I. II, and III of the ECG and LV pressures were recorded simultaneously. Using a Siemens Elema Siereg 800016 channel recorder, $\mathrm{P}_{\mathrm{ed}}^{\mathrm{l}} \mathrm{d}$ was recorded at a speed of $50 \mathrm{~mm} / \mathrm{sec}$. Ply was calculated by hand using the point $0.06 \mathrm{sec}$. after the onset of the QRS-complex at which the mitral valve is supposed to close $(73,74)$.

Scores of $P$ ed were divided in 3 categories:

category $1: \leqslant 12 \mathrm{mmHg}$.

category $2: 13-19 \mathrm{mmHg}$.

category $3: \geqslant 20 \mathrm{mmHg}$. 
Table XII gives the number of patients from each of these categories.

Table XII.

Division of the 303 patients into three categories according to their left ventricularend-diasiolic pressure

\begin{tabular}{|c|c|}
\hline & $N$ \\
\hline$P_{\mathrm{cd}}^{1 \mathrm{k}} \leqslant 12 \mathrm{mmHg}$ & 175 \\
\hline $\mathrm{Ped}^{13} 13-19 \mathrm{mmHg}$ & 85 \\
\hline $\mathrm{p}_{\mathrm{cd}}=20 \mathrm{mmHg}$ & 43 \\
\hline
\end{tabular}

Abbreviation: $\mathrm{p}_{\mathrm{ed}}^{\mathrm{lv}}=$ left ventricular end-diastolic pressure.

\section{Left ventriculography}

Following hemodynamic measurements, left ventriculography was performed. At first the $60^{\circ} \mathrm{LAO}$-projection was used, followed, 3-5 minutes later, by the $30^{\circ}$ RAO-projection.

The image intensifier tube of the Siemens Angioscope-U was positioned as closely as possible to the patient's body.

Films were exposed at a speed of 50 frames per second, using a $35 \mathrm{~mm}$ Arriflex camera mounted on a 9 inch image intensifier.

Half of the body weight (in $\mathrm{kgs}$ ) in cc of Isopaque Coronar $\mathrm{R}$ was injected at a flowrate of $14 \mathrm{cc}$ per second. The injector used, was a Siemens Contrac 4 or a Medrad mark IV. The Kodak 2496 films were developed using an Oude Delft combilator.

\section{d. Measurements on the left ventriculogram}

In order to perform the measurements of segmental wall motion with the method of the Stanford group (1), the films were projected on the screen of an Arriflex RGT 35. A transparent sheet of paper was fixed to the screen.

Without moving the paper, the and-systolic and end-diastolic contours in both projections were drawn. By assuming that the chest of the patient was the fixed external reference, no corrections were made for motion of the heart. The end-systolic contour was defined as the smallest $L$ V contour. In those patients where a late systolic contraction pattern of a hypokinetic area was present, the frame showing the most inward position of the best contracting part was used. The end-diastolic contour was the largest $L$ V contour.

According to the procedure described by lngels, a line was drawn in the end-systolic $30^{\circ} \mathrm{RAO}$-projection between the laterall aortic valve edge $(\mathrm{B})$, and the most distant point of the apex $(C)$. Point $A$ was defined as lying on the line $B C$, where $A B$ was $69 \%$ and $\mathrm{AC} 31 \%$ of the length of $\mathrm{BC}$ (figure 7 ). 
Figure 7 shows the " $6 \% \%$ point" $A$, on the line betwen the tateral aortic valve edge $B$, and the most distant point of the apex $\mathrm{C}$. in the end-systolic frame in 30 RAO-projection.

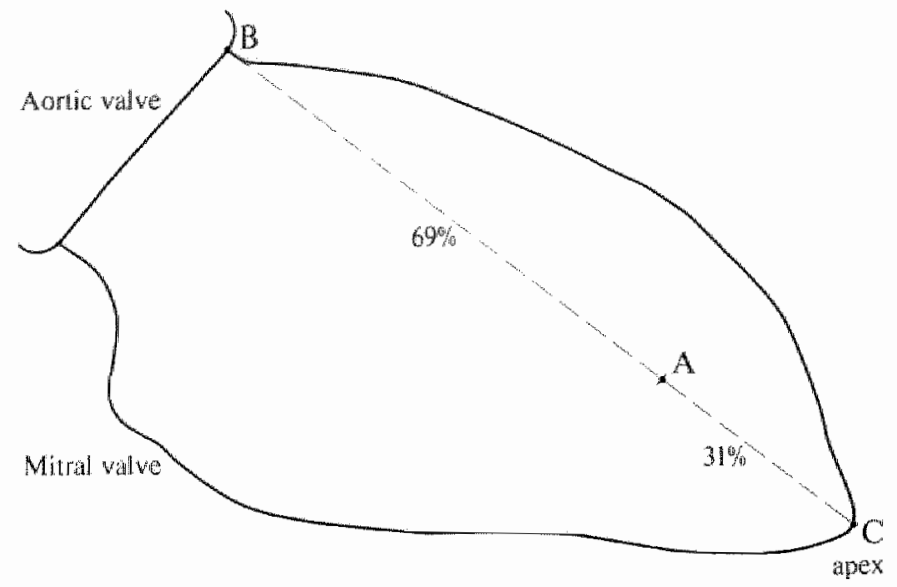

For wall motion analysis, analogous to the segmentation commonly used by clinical angiographers, the RAO-frames were divided into 5 segments: segment 1: anterobasal; segment 2: antero-lateral; segment 3: apical; segment 4: inferior; segment 5: postero-basal (2).

Alderman et al (62) defined the apical segment by an angle $\alpha$ on either side of the long axis line ( $\mathrm{BC})$. His criterion for the size of this angle $a$ was not given.

Because of the advantage of having the same fixed angles in all patients, we subjectively estimated the size of the apical segment, using the criteria of Gensini (2), in 30 non-coronary patients having atypical chest pain with a normal left ventriculogram. The estimated angle $\alpha$ for the apical segment proved to be very constant. In all 30 . patients, an angle $\alpha$ of approximately $40^{\circ}$ was found (figure 8 ).

We also measured the angle $\beta$ between the mitral valve fornix and the lateral aortic valve edge. The mean angle $\beta$ for the 30 patients was found to be $61.4^{\circ} \pm 6.3$ (figure 8). For the purpose of simplicity we have chosen an angle $\beta$ of $60^{\circ}$. 
Figure 8 shows both angles $\alpha$ from the "69\% point" A that determine the apical segment. Angle $\beta$ is also shown, which is the angle beiween mitral walve fornix and the lateral aortic walwe edge in the ondsystolic $30^{\circ} \mathrm{RAO}$-projection.

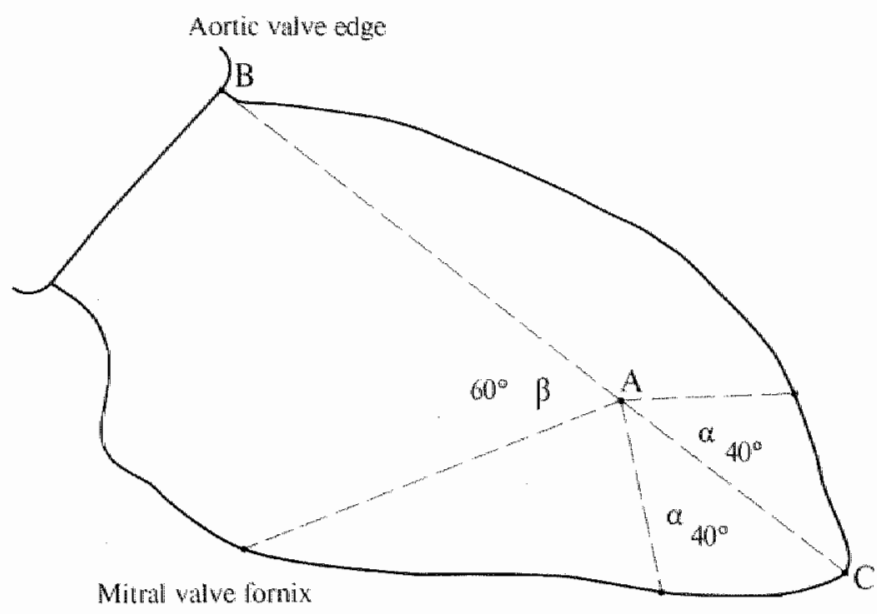

To be certain that these angles $\alpha$ and $\beta$ could also be used in patients with asynergy, 30 ventriculograms of patients with a large and proven myocardial infarction, having a maximal SGOT value of more than $200 \mathrm{U} / 1$ (40 U/l being the upper limit of normal), were measured. The same findings were present for both angles $\alpha$ and $\beta$. From this data we concluded that using fixed angles in the RAO-projection is acceptable in defining the 5 segments.

Using Alderman's method (62), the inferior and anterior walls are subdivided on the basis of a $1 / 3: 2 / 3$ ratio of the residual angle between the boundaries of the noncontractile (valvular) portion, and the edges of the apical segment of the LV systolic silhouette. Using his method, we conclude that segment I has an angle of $46 \% 3^{\circ}$; segment $2: 931^{\circ} ;$ segment $3: 80^{\circ} ;$ segment $4: 5313^{\circ}$; and segment $5: 26 \% 3^{\circ}$. This is shown in figure 9.

Figure 9 gives the vahues of the angles of the 5 segments in the end-systolic $30^{\circ}$ RAO-projection.

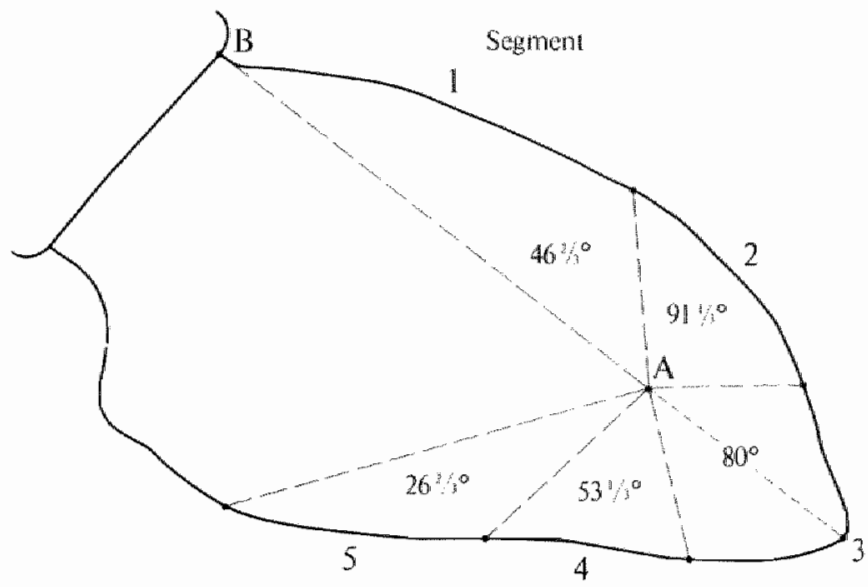


Ingels el al do not provide data regarding measurements in $60^{\circ} \mathrm{LAO}$-projection. In this projection, definition of the long axis is frequently extremely difficult because the apex is often projected within the ventricular shadow.

Ingels' conclusions strongly suggest that the error in localization of the centric point is far less important than that which is caused by frame by frame indexing. This is why we used the fixed external reference system in $60^{\circ} \mathrm{LAO}$-projection in the same manner as we already discussed in the $30^{\circ} \mathrm{RAO}$-projection.

The centric point is defined as follows: Line DE is the line between septal aortic valve edge (D) and mitral aortic valve edge (E). In the middle of this line DE, a second line is drawn at an angle of $90^{\circ}$ towards the ventricle. The " $69 \%$ point" $F$ of this second line of the end-systolic contour is used as the centric point (figure 10).

Findre 10 show the crd-systolic $60^{\circ}$ LAO projection of the let ventricte. The midpoint of the line DE, betwen the mitral and septal aortic walve cdge, is divided by ascond line a an angle of $90^{\circ}$ toward the vertricle, On this line, the "69\% point" 1 is dekrmined.

Aortic valve

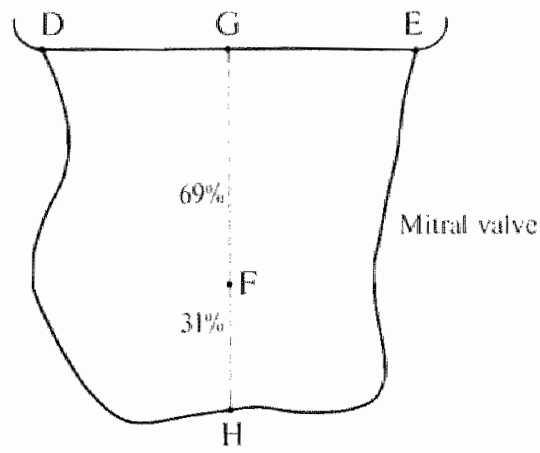

To make clinical comparison in the LAO-projection, a division in 2 segments was made: segment 6 as the septal segment, and segment 7 as the postero-lateral segment.

Using the previously described 30 control patients, we empirically determined segments 6 and 7 . It was found that angle DFG was $40.4^{\circ}+4.7$, which means that segment 6 started at a mean of $40.4^{\circ}$ from line $\mathrm{FG}$ at the septal aortic valve edge (figure 11). For the purpose of simplicity an angle of $40^{\circ}$ was chosen.

The border between segments 6 and 7 was line FH, at a mean of $151.9^{\circ}+9.3$ from line $\mathrm{FG}$. An angle of $150^{\circ}$ was chosen.

The other border of segment 7 was line FJ, at a mean $122.3^{\circ}+11.4$ at the other side of line FG. An angle of $120^{\circ}$ was chosen.

From this data we conclude that segment 6 has an angle of $110^{\circ}$ and segment 7 of $90^{\circ}$ (figure 11). 
Figure 11 shows the end-systolic $60^{\circ}$ LAO-projection of the left ventricle. The septal segmem 6 has an angle of $110^{\circ}$. The postero-lateral segment 7 has an angle of $90^{\circ}$.

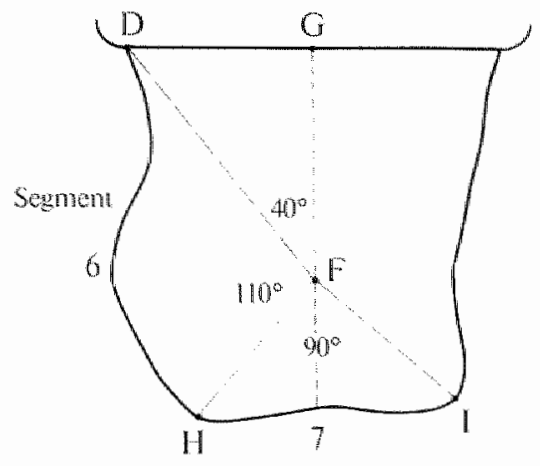

One has to realize that segment 6 does not always reflect septal wall motion. In the chosen projections we were not able to differentiate between the septum and anterior wall in some patients.

Measurements done in the $60^{\circ} \mathrm{LAO}$-projection in the 30 myocardial infarction patients gave identical results. In using the Stanford method for LV wall motion assessment, one particular problem arose. In the $30^{\circ}$ RAO-projection, segment 1 , the antero-basal area, could not be measured in a number of cases because inward movement of that segment during systole crossed the long axis. We found that in all these cases, wall motion of that segment was normal or hyperkinetic. Because our interest was to correlate the ECG with normal versus hypo-,a-or dyskinesis, and not hyperkinesis, the systolic contour of that segment was drawn close to the long axis at the other site of that line (see figure 12). Using this correction, segment 1 was classified as normal in all these cases.

Figure 12 shows the real contours of both end-diastolic (closed lines) and end-systolic frames (open limes). In this figure, a correction of the end-systolic contour of segment I to the other side of the long axis was made in order to provide calculations (see arrow).

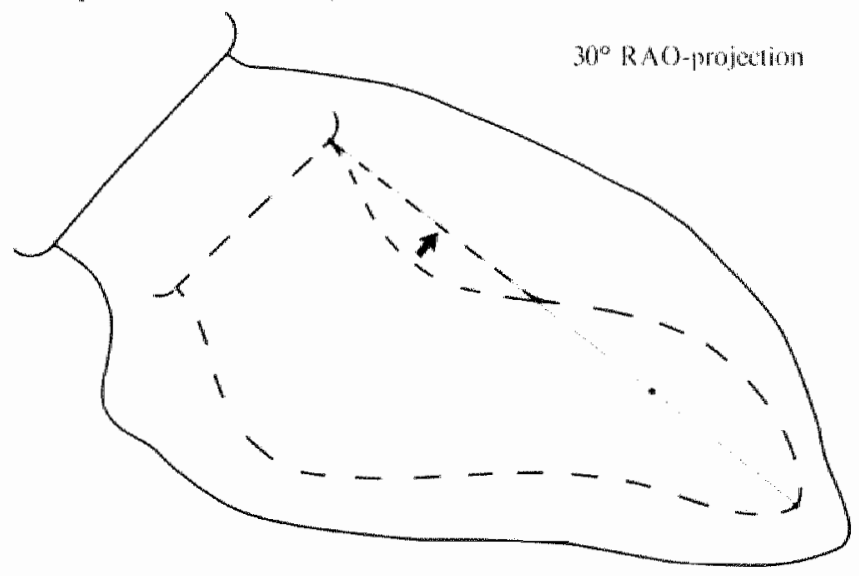


As is the case with all presently available methods used for measuring ventricular wall motion, it must be understood that these estimations and calculations cannot be absolutely accurate. Several of the possible errors will present themselves systematically in all ventriculograms because of the method. Individual errors will also be presemt and cannot be completely prevented (75). To make individual errors as small as possible, special attention was given to:

a) Optimal film quality.

b) Optimal contrast filling in order to enhance visualization of the contour of the left ventricle.

c) Rejection of premature ventricular contractions and post-extrasystolic beats.

d) Identification of the position of the lateral aortic valve edge and the most distant point of the apex in $30^{\circ}$ RAO-projection.

e) Identification of the position of the septal and the mitral aortic valve edge in the $60^{\circ} \mathrm{LAO}$-projection.

All drawings of the 303 patients were checked twice by the same observer before being accepted for analysis.

After making drawings of both contours and calculation of the centric point in both projections, segmental motion was analysed on a "Digitizer" HP 9874A and drawn on a "Plotter" HP 9862A as a control measurement. This system was programmed to compute percentile shortening of all the 7 segments. This was done by taking points on the end-diastolic contour with a real distance of $0.5 \mathrm{~cm}$. From these points, the digitizer computed polar co-ordinates to the $69 \%$ point, and the crossing points of these co-ordinates and the end-systolic contour. The percentile shortening of a mean co-ordinate was the length of the diastolic, minus the systolic co-ordinate, divided by the length of the diastolic co-ordinate. The percentile shortening of a segment was the mean shortening of all co-ordinates in one segment.

in oruer to de iermine the accuracy of our measumements, we critically analysed every step taken:

1. Biplane left ventriculography.

2. Selection of the optimal sinus beat.

3. Selection of the end-systolic and end-diastolic frame.

4. Drawing of both contours.

5. Reading of contours in the digitizer.

6. Calculation of segmental motion.

The following control studies were done:

a. Step 5/6: Of 3 ventriculograms, every contour was read 5 times.

b. Step 4/5/6: In 3 ventriculograms a drawing of the same frames was made 5 times without moving the film.

c. Step 3/4/5/6: In 3 ventriculograms a drawing of the same sinus beat was made 5 times. We always started by newly projecting the film to search the end-systolic and end-diastolic frame.

d. Step 2/3/4/5/6: In 5 ventriculograms contours in both projections were drawn of 3 consecutive sinus beats. 
e. In 20 patients, selected at random, contour drawings were made. This procedure was repeated several hours to days later.

We assumed that the error in our measurements was independent of the absolute value. For steps a - $d$ the range of values of 15 samples, which was done by subtracting the lowest from the highest value, was calculated for each segment. These 15 samples were taken either 5 times in 3 patients (steps a - c), or 3 times in 5 patients (step d). Because 7 segments were measured, the total number of measurements for every step was $7 \times 15=105$ measurements. For step e the range of values between the 2 procedures, done by subtracting the lowest from the highest value, was evaluated, giving a total number of $7 \times 20=140$ measurements. From this data the mean range was calculated for every step.

In table XIII the mean range is given for the control studies a through e.

Table XIIr.

The mean range of the five different steps of the left ventricular analysis

\begin{tabular}{llllll}
\hline & $\begin{array}{l}\text { Siep } \\
a\end{array}$ & $b$ & $c$ & $d$ & $e$ \\
\hline Mean range $(\%)$ & 3.5 & 9.7 & 11.3 & 8.8 & 6.6 \\
\hline
\end{tabular}

These differences are divided more or less equally over all segments. Table XIV shows an example of the results of the control study e subdivided into the 7 segments.

\section{Table XIV.}

The mean range of the individual 7 segments of stepe

\begin{tabular}{|c|c|c|c|c|c|c|c|}
\hline \multicolumn{8}{|c|}{ Segment } \\
\hline & $j$ & 2 & 3 & 4 & 5 & 6 & 7 \\
\hline Meanrange (\%) & 5.4 & 7.4 & 5.3 & 6.6 & 8.4 & 6.1 & 7.0 \\
\hline
\end{tabular}

In conclusion, the most important source for errors is step b, although the other steps show marked variations. This finding was in agreement with those of Chaitman et al (45). 


\section{Chapter 4}

a. Definition and classification of normal and abnormal segmental wall motion

To obtain information about normal segmental wall motion, 61 patients with atypical chest pain were studied. None of these patients had coronary artery disease. In 45 of the 61 patients, no abnormalities were found. Fourteen patients had no cardiac abnormalities apart from a prolapsed mitral valve. Two patients were studied after recovery from an episode of chest pain due to idiopathic pericarditis in order to exclude coexistent coronary artery disease. In these two patients no abnormalities were found.

Table XV shows the mean, the standard deviation, and the range of the wall motion of the seven $L V$ segments in these 61 patients.

Table XV.

Segmental wall motion in patients with atypical chest pain $(N=61)$

\begin{tabular}{lccccccc}
\hline & Segmenr & & & & & \\
& 1 & 2 & 3 & 4 & 5 & 6 & 7 \\
\hline mean & 34.5 & 67.2 & 50.8 & 52.9 & 39.7 & 41.9 & 49.1 \\
S.D. & 8.4 & 14.3 & 11.6 & 10.1 & 12.5 & 13.6 & 9.8 \\
range & $11-51$ & $36-99$ & $28-70$ & $23-72$ & $7-66$ & $18-89$ & 27.70 \\
\hline
\end{tabular}

Abbreviation: S.D. = standard deviation.

A graphic representation of the distribution of segmental wall motion is given in table XVI. Although the numbers were insufficient to determine the exact Gaussian range, visual inspection of the curves suggest, except for segment 2 , an acceptable Gaussian fit.

For determination of the $95 \%$ border at one side of the curve (the lower), the following formula was used:

$95 \%$ border $=$ Mean $-1,65 \times$ Standard Deviation (76) 


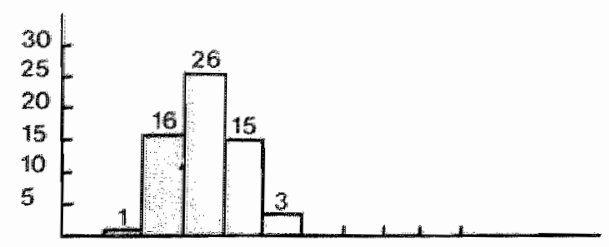

TABLE XVI. DISTRIBUTION OF SEGMENTAL SHORTENING IN THE GI PATIENTS WITH ATYPICAL CHEST PAIN
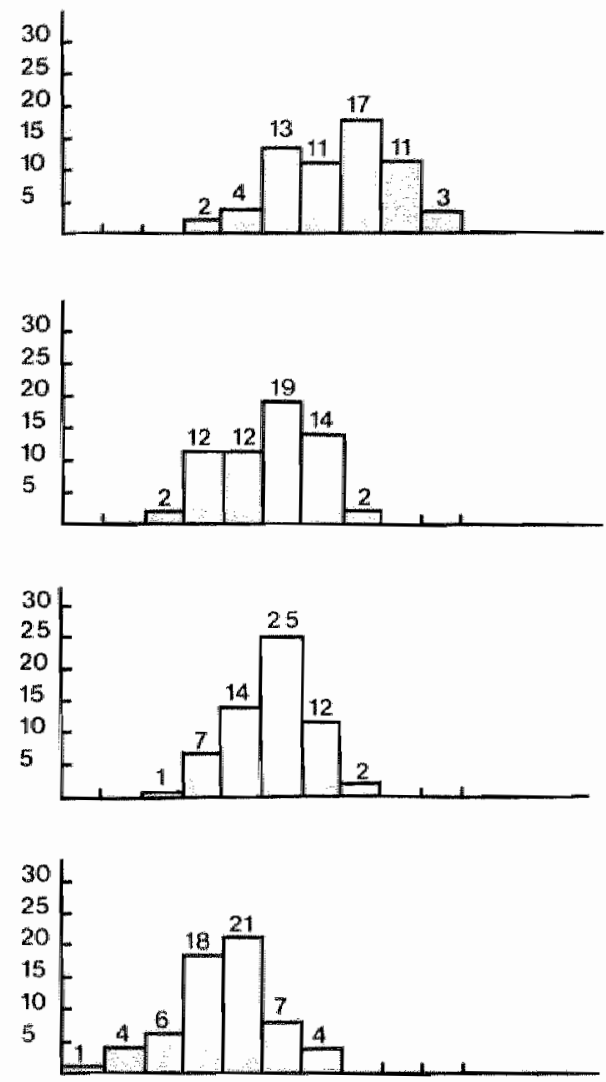

4

5

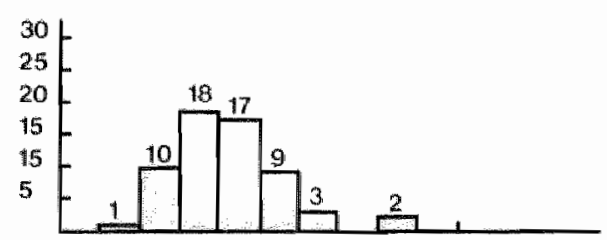

6

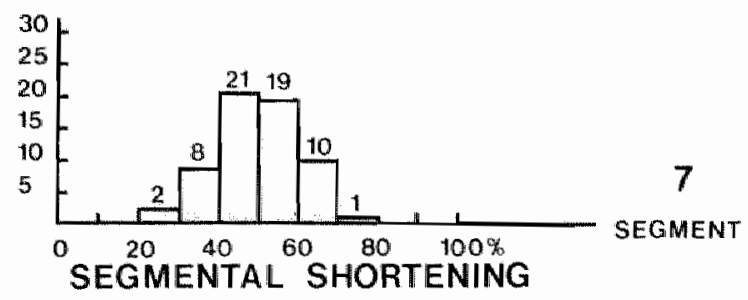


Using this formula $a_{n}$ the cut-off point between normal and abnormal wall motion was for segment $1: 21 \%$; segment $2: 44 \%$; segment $3: 32 \%$; segment $4: 36 \%$; segment $5: 19 \%$; segment $6: 20 \%$; and segment $7: 33 \%$. These values were used for further calculations.

The patients with asynergy were subdivided into 3 groups: In patients with hypokinesis wall motion was reduced to between $>5 \%$ and the cut-off point as described above. Akinesis, or absence of wall motion, was defined as wall motion $\geqslant-5 \%$ to $\leqslant$ $+5 \%$. For dyskinesis or paradoxical LV wall motion, a wall motion $<-5 \%$ was required.

Using all these criteria for our patients with atypical chest pain, it was found that 48 . 61 patients $(79 \%)$ had a normal contraction pattern in all segments. However, in $21 \%$, asynergy was present in one or more segments. All patients with asynergy proved to have hypokinesis.

Using the described method as a reference method, we compared this method with subjective interpretation of LV wall motion done by the author in all 303 patients. Three possibilities were open for the subjective method:
a. synergy,
b. asynergy,
c. dubious.

Table XVII shows the results of the correlation between the two methods. Of the 120 patients with synergy according to the subjective method, 16 patients (13\%) showed to have hypokinesis using the objective method. Only 2 of the 117 patients $(2 \%)$ with asynergy according to the subjective method were classified in the synergy group of the objective method. None of the dubious patients had a- or dyskinesis.

Table XVII.

Correlation between subjective and objective method for left ventricular wall motion assessment

\begin{tabular}{llccc}
\hline & \multicolumn{3}{c}{ Subjective merhod } \\
\hline & & synergy & asynergy & dubious \\
\hline Objective & Synergy & 104 & 2 & 19 \\
method & hypokinesis & 16 & 51 & 47 \\
& akinesis & 0 & 41 & 0 \\
& dyskinesis & 0 & 23 & 0 \\
\hline
\end{tabular}

The value of the $60^{\circ} \mathrm{LAO}$-projection

In $18 / 303$ patients $(6 \%)$, asynergy was exclusively found in $60^{\circ} \mathrm{LAO}-$ projection. In 89 of these 303 patients ( $29 \%$ ), more severe asynergy was present in the LAO, than the RAO-projection. 
b. Segmental wall motion in relation to certain electrocardiographic patterns

\section{General sispects}

In table XVIII segmental wall motion of the 7 segments is shown for all 303 patients.

Table XVIII.

Mean, standard deviation, and percentage of abnomal segmental wall motion in pationts with and withour bundle branch block, with low woltage, and with notching in absence of bundle branch block

\begin{tabular}{|c|c|c|c|c|c|c|c|c|}
\hline & & \multicolumn{7}{|c|}{ Segment } \\
\hline & & 1 & 2 & 3 & 4 & 5 & 6 & 7 \\
\hline \multirow{3}{*}{$\begin{array}{l}\text { All paticnts } \\
N=303\end{array}$} & mean & 28.1 & 52.9 & 36.5 & 409 & 34.9 & 30.4 & 39.6 \\
\hline & $S D$ & 10.6 & 27.3 & 23.1 & 20.0 & 17.2 & 17.6 & 14.9 \\
\hline & $a b m$ & 23 & 32 & 36 & 33 & 20 & 26 & 31 \\
\hline \multirow{3}{*}{$\begin{array}{l}\text { All paticnts } \\
\text { except BBB } \\
N=280\end{array}$} & mean & 28.7 & 54.4 & 37.8 & 42.3 & 35.7 & 31.4 & 40.7 \\
\hline & S.D. & 10.4 & 27.0 & 229 & 19.5 & 16.9 & 17.3 & 14.4 \\
\hline & abn $\%$ & 21 & 30 & 35 & 30 & 21 & 24 & 30 \\
\hline \multirow{3}{*}{$\begin{array}{l}\text { Low wollage } \\
N=22\end{array}$} & mean & 18.6 & 26.3 & 14.0 & 33.1 & 35.0 & 190 & 28.5 \\
\hline & So. & 9.7 & 25.1 & 24.5 & 22.4 & 15.9 & 16.0 & 17.4 \\
\hline & abn. $\%$ & 59 & 68 & 73 & 50 & 23 & 64 & 64 \\
\hline \multirow{3}{*}{$\begin{array}{l}\text { Notching } \\
\text { except BBB } \\
N=29\end{array}$} & mean & 23.3 & 38.8 & 30.2 & 38.0 & 31.9 & 22.5 & 38.3 \\
\hline & S.D. & 12.0 & 31.7 & 26.5 & 20.9 & 16.0 & 18.1 & 17.1 \\
\hline & abn. $\%$ & 41 & 59 & 52 & 38 & 28 & 52 & 34 \\
\hline
\end{tabular}

Abbrevations: $\mathrm{BBB}=$ bundle branch block: S.D. = standard deviation; abn $\%$ = abnormal percentage.

Of these patients, 280 patients had a narrow QRS-complex $(<0.12 \mathrm{sec}$.), 22 patients had low voltage, and 29 patients notching in the ascending, or descending, limb in one or more leads. In the subsequent tables we will also show wall motion findings in patients having wide QRS-complexes, and the influence of frontal plane clectrical axis on LV contraction pattern. In each electrocardiographic pattern, the mean walue, and the standard deviation for regional wall motion is given. The percentage of patients having an abnormal segmental wall motion is also shown. The group of patients having narrow $Q R S-c o m p l e x e s(<0.12 \mathrm{sec}$.) was examined separately from the total group of patients to make comparison possible, because correct interpretation of the significance of certain ECG-patterns, like ST-segments, can be impossible in the presence of bundle branch block.

\section{Low voltage}

Twenty-one of the 22 patients ( $95 \%$ ) with low voltage had asynergy. This was found in all segments, but segment 5 . Half of them (10/21 patients) had hypokinesis; $6 / 21$ patients $(29 \%)$ had akinesis; and $5 / 21$ patients $(24 \%)$ had dyskinesis.

\section{Norching}

Notching is frequently encountered in patients with wide QRS-complexes $(\geqslant 0.12$ $\mathrm{sec}$.). It can also be present in patients with narrow QRS-complexes. Fibrosis, sub- 
sequent to myocardial infarction, could be the cause for notching (77). We therefore selected the patients with notching in the ascending or descending limb of the QRS-complex in the absence of a wide QRS-complex. We found that in these patients, the antero-lateral, apical, and septal areas notably showed a higher incidence of asynergy. Ten out of 29 patients $(34 \%$ ) had a normal contraction pattern. Of the 19 patients with asynergy, $9 / 19$ patients ( $47 \%$ ) had hypokinesis, $6 / 19$ patients $(32 \%)$ had akinesis, $4 / 19$ patients $(21 \%)$ had dyskinesis.

\section{Frontal plane electrical axis}

The relationship between segmental wall motion and the frontal plane electrical axis is given in table XIX. In patients with left axis deviation, all segments had a high

Table XIX.

Mean, standard deviation, and percentage of abnormal segmental wall motion in patients with right, normal, and left frontal plane electrical axis

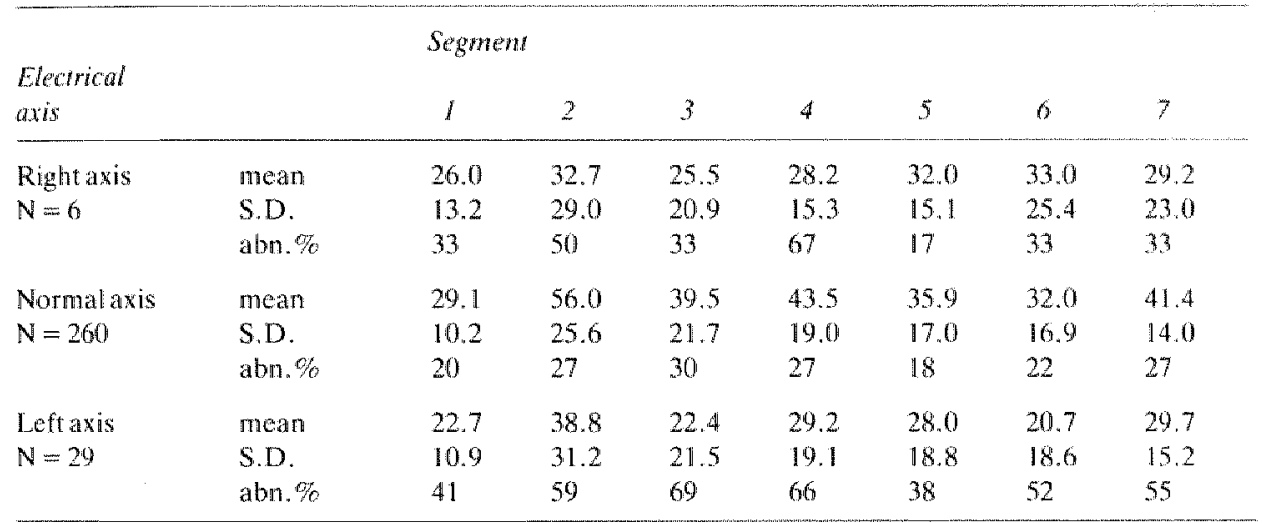

Abbreviations: as in table XVIII.

percentage of abnormal wall motion. Abnormalities were less frequent in patients showing right axis deviation. Most of the patients having an intermediate axis were normal. 
Wide QRS-complexes ( $\geqslant 0.12 \mathrm{sec}$.)

More than half of the patients with a ORS-width $\geqslant 0.12 \mathrm{sec}$. had an abnormal contraction pattern in all segments (table $\mathrm{XX}$ ).

Table XX.

Mean, standard devation, and percentage of abnomal segmental wall motion in patients with bundle branch block, right bundle branch block, and left bundle branch block

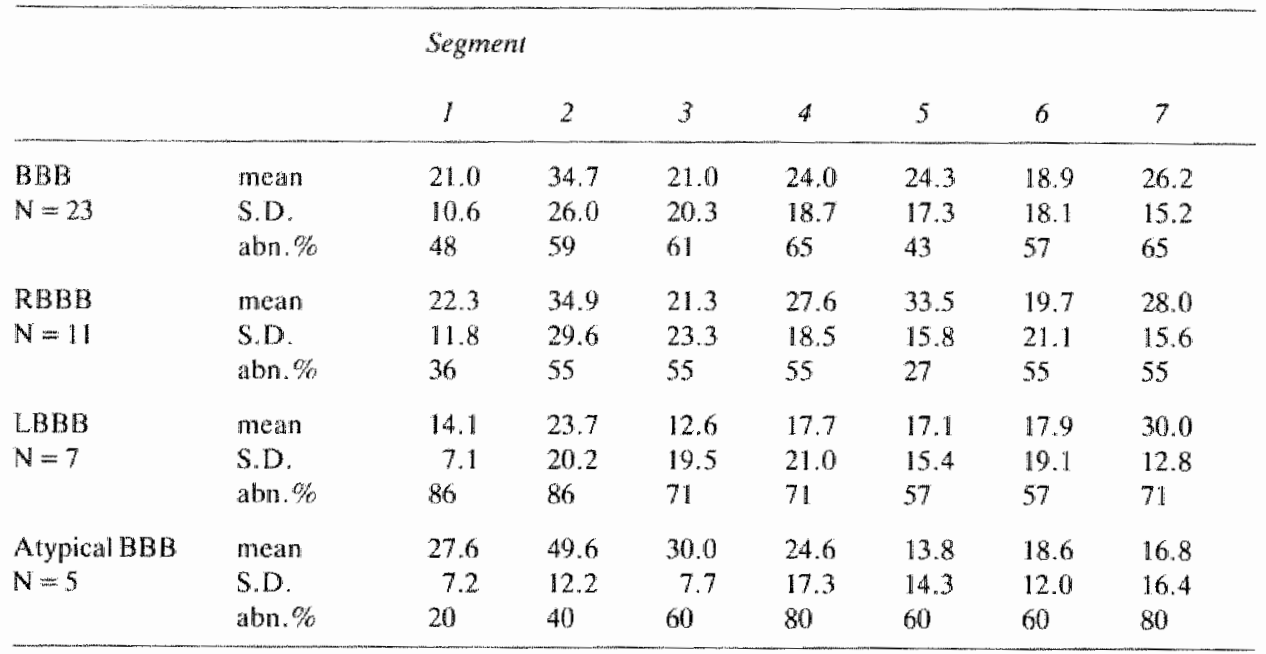

Abbreviations: as in table XVIII. RBBB = right bundle branch block; LBBB = left bundle branch block; $\mathrm{BBB}=$ bundle branch block.

Five of the patients with right bundle branch block had the conduction disturbance subsequent to an extensive anterior wall infarction. Half of the other patients with right bundle branch block had a normal wall motion of the left ventricle. In all patients with left bundle branch block, left axis deviation was present. Two patients had a previous infarction. Most patients with left bundle branch block showed generalized disease of the left ventricle. Twenty of the $23(87 \%)$ patients with wide QRS-complexes had asynergy in one or more segments, $4 / 20$ patients $(20 \%)$ had dyskinesis, 1020 patients $(50 \%)$ akinesis, and $6 / 20(30 \%)$ hypokinesis.

All 5 patients having an atypical bundle branch block had asynergy. One patient had hypokinesis, 4 patients had akinesis.

\section{Myocardial infarction}

\section{Previous infarct}

Of the 218 patients with coronary artery disease, 129 patients had a documented myocardial infarction, 87 patients had no documented myocardial infarction, and 2 patients had a typical history, but no proof of myocardial infarction. These last $2 \mathrm{pa}-$ tients were excluded from table XXI. There were significant differences in all $7 \mathrm{seg}$ ments between the two groups. The patients with a previous myocardial infarction had a higher incidence of abnormal segmental wall motion, than those without. 
Mean, standard deviation. and percentage of abnormal segmental wall motion in patients with or without a previous myocardial infarction

\begin{tabular}{|c|c|c|c|c|c|c|c|c|}
\hline & & \multicolumn{7}{|c|}{ Segment } \\
\hline & & $l$ & 2 & 3 & 4 & 5 & 6 & 7 \\
\hline Noprevious & mean & 31.4 & 64.3 & 46.5 & 49.6 & 38.6 & 37.0 & 43.8 \\
\hline infarct & S.D. & 8.3 & 19.3 & 17.7 & 13.9 & 15.3 & 11.2 & 11.3 \\
\hline$N=87$ & abn. $\%$ & 11 & 13 & 14 & 11 & 9 & 4 & 19 \\
\hline Prewious & mean & 22.8 & 38.0 & 22.6 & 29.0 & 30.0 & 20.0 & 31.8 \\
\hline infarct & S.D. & 10.4 & 30.1 & 23.6 & 21.0 & 18.7 & 17.5 & 15.2 \\
\hline$N=129$ & $a b n . \%$ & 41 & 54 & 66 & 62 & 34 & 55 & 53 \\
\hline
\end{tabular}

Abbreviations: as in table XVIII.

Fourteen of the 129 patients $(11 \%)$ with a previous infarct had synergy of all segments. Of the 87 patients with no previous infarct, 36 patients $(41 \%)$ had asynergy. Only 3 of these 36 patients had akinesis or dyskinesis. On the other hand, of the 178 patients having an abnormal contraction pattern in one or more segments, $65 \%$ had previously infarcted. In 21 patients with one documented previous infarct, no "infarct"ECG was found at the time of catheterization (table XXII). In this group of 21

\section{Table XXII.}

Infaret localization in patients with previous ECG documentation of myocardial infarction using older ECGs after disappearance of the $\mathrm{Q}$-waves

\begin{tabular}{lcccc}
\hline & \multicolumn{3}{c}{ Disappeared Infarct-localization on old ECGs } \\
$\begin{array}{l}\text { Previous infarct } \\
\text { notvisibleon ECG }\end{array}$ & Anterior & Inferior & Posterior & Lateral \\
\hline $\begin{array}{l}\text { One infarct } \\
21 / 103 \text { patients }\end{array}$ & 6 & 8 & 6 & \\
$\begin{array}{l}\text { Two infarcts } \\
14 / 26 \text { patients }\end{array}$ & 2 & & & 6 \\
\hline
\end{tabular}

patients, the infarct localization in older electrocardiograms showed a lesion in the anterior wall in 6 patients, in the inferior wall in 8 patients, in the posterior wall in 6 patients, and in the lateral wall also in 6 patients. Only $65 \%$ of these 21 patients had asynergy, none of the asynergy patients showed dyskinesis, $38 \%$ had akinesis, and $62 \%$ hypokinesis. This is in sharp contrast to the 109 patients with a previous infarct, who still had the typical electrocardiographic myocardial infarction pattern. Hundred and one of the 109 patients $(94 \%)$ had asynergy. These 101 patients showed dyskinesis in $21 \%$, akinesis in $31 \%$, and hypokinesis in $50 \%$. Of the 26 patients who suffered twice from a previous myocardial infarction, in only 12 was an "infarct"-ECG present in two areas at the time of catheterization. The distribution was: 2 in the anterior, 6 in the inferior, 4 in the posterior, and 2 in the lateral wall. 
Q.waves

Table XXII gives the segmental wall motion of the 7 segments in relation to $Q$ waves found in all leads. Only patients with a narrow QRS-complex $(<0.12$ sec.) are presented. The O-wave was not necessarily isolated, but could also be present in other leads. Precordial $Q$ 's were accompanied by more severe segmental wall motion abnornalities. Q-waves in leads $V_{2}, V_{3}, V_{4}$, wnd $V_{5}$ were commonly associated with a high percentage of asynergy. This was not only seen in the expected Table XXIII.

Mean, stundard deviation, and percentage of abnormal segmental wall motion in patients with a $Q$-wave or OS-complex

Segment

\begin{tabular}{|c|c|c|c|c|c|c|c|c|}
\hline Q-wat & & $l$ & 2 & 3 & 4 & 5 & 6 & 7 \\
\hline 1 & mean: & 21.0 & 24.5 & 14.2 & 306 & 340 & 17.7 & 32.5 \\
\hline \multirow[t]{2}{*}{$N=21$} & $\$, D$ & 12.2 & 29.5 & 24.1 & 25.2 & 18.4 & 20.5 & 17.4 \\
\hline & abn, $/ 6$ & 62 & 71 & 81 & 48 & 29 & 67 & .57 \\
\hline$\llbracket$ & mean & 20.3 & 39.7 & 19.9 & 18.4 & 19.4 & 21.9 & 25.9 \\
\hline \multirow[t]{2}{*}{$N=29$} & S.D. & 7.2 & 27.3 & 18.7 & 17.4 & 15.2 & 16.7 & 12.5 \\
\hline & abn. $\%$ & 35 & 55 & 76 & 86 & 59 & 55 & 72 \\
\hline III & mean & 27.9 & 51.2 & 31.8 & 30.0 & 26.7 & 27.1 & 33.6 \\
\hline \multirow[t]{2}{*}{$N=76$} & S.D. & 10.2 & 26.8 & 22.1 & 21.1 & 18.1 & 15.4 & 15.1 \\
\hline & abn. $\%$ & 19 & 34 & 49 & 61 & 40 & 34 & 49 \\
\hline AVL & mean & 21.6 & 29.5 & 23.2 & 38.9 & 37.5 & 21.0 & 36.0 \\
\hline \multirow[t]{2}{*}{$N=42$} & S.D. & 11.5 & 30.0 & 25.7 & 22.3 & 17.0 & 19.9 & 15.1 \\
\hline & $\operatorname{sbn} \%$ & 52 & 62 & 60 & 33 & 17 & 57 & 36 \\
\hline$A V F^{-}$ & rucan & 24.3 & 46.7 & 25.0 & 24.3 & 22.8 & 24.0 & 28.9 \\
\hline \multirow[t]{2}{*}{$N=49$} & S.D. & 8.8 & 27.5 & 21.0 & 19.1 & 17.5 & 16.1 & 13.6 \\
\hline & abn. \% & 29 & 41 & 65 & 74 & 53 & 43 & 67 \\
\hline$V_{1}$ & moan & 22.6 & 32.8 & 20.8 & 34.7 & 40.6 & 18.8 & 39.0 \\
\hline \multirow[t]{2}{*}{$N=38$} & S.D. & 12.0 & 35.4 & 30.4 & 23.8 & 14.2 & 22.5 & 16,3 \\
\hline & abn $\%$ & 50 & 58 & 68 & 47 & 8 & 66 & 37 \\
\hline & mean & 16.8 & 15,3 & 8.2 & 28.4 & 39.8 & 8.2 & 33.6 \\
\hline \multirow[t]{2}{*}{$N^{2}=38$} & S.D. & 10.3 & 28.0 & 20.9 & 23.0 & 16.9 & 11.7 & 13.8 \\
\hline & abn. $\%$ & 76 & 84 & 95 & 63 & 13 & 90 & 47 \\
\hline & mesn & 15.8 & 13.0 & 5.4 & 26.8 & 39.8 & 8.2 & 33.2 \\
\hline \multirow[t]{2}{*}{$N=40$} & S.D. & 7.3 & 21.4 & 15.4 & 21.1 & 16.2 & 10.9 & 13.6 \\
\hline & abn. 唯 & 78 & 90 & 100 & 63 & 13 & 88 & 50 \\
\hline$V_{4}$ & mean & 17.0 & 16.4 & 8.3 & 26.9 & 39.0 & 9.3 & 33.8 \\
\hline \multirow[t]{2}{*}{$N=28$} & S.D. & 9.0 & 24.4 & 17.8 & 21.3 & 17.0 & 11.3 & 15.5 \\
\hline & abn $\%$ & 64 & 82 & 93 & 57 & 14 & 89 & 43 \\
\hline & mean & 16.9 & 17.6 & 4.2 & 24.5 & 34.5 & 11.6 & 29.6 \\
\hline \multirow[t]{2}{*}{$N=15$} & S.D. & 8.7 & 25.1 & 14.7 & 20.4 & 19.8 & 7.0 & 13.5 \\
\hline & abnu $\%$ & 67 & 80 & 100 & 67 & 27 & 93 & 53 \\
\hline & moan & 18.9 & 26.8 & 11.4 & 15.7 & 20.3 & 15.7 & 18.4 \\
\hline \multirow[t]{2}{*}{$N=9$} & S.D. & 10.0 & 19.5 & 12.6 & 100 & 14.2 & 16.6 & 8.8 \\
\hline & $a_{n} \%$ & 56 & 78 & 89 & 89 & 56 & 67 & 89 \\
\hline
\end{tabular}

Abbrevintions: as in table XVIIL. 
antero-lateral, apical, and septal areas (segments 2, 3, and 6, respectively), but also in the surrounding antero-basal and inferior areas (segments 1 and 4 ).

Interestingly, precordial Q's did not exhibit such influence on segment 5 (posterobasal area), except for a $Q$-wave in lead $V_{6}$ ! $A$ Q-wave in this lead indicated generalized wall motion abnormalities in all segments, including segment 5 (postero-basal area), and also in a significant percentage of cases in segment 7 (postero-lateral area).

The finding that $Q S$-complexes in lead $V_{1}$ correlated with a high percentage of normal wall motion in segment $5(92 \%)$, is of importance.

When Q-waves were present in the extremity leads, abnormalities were more localized. Nevertheless, here the presence of $Q$-waves influenced all segments, though to a lesser extent, than precordial Q"s. Q-waves in lead III were related to abnormalities in segment 4 . The influence of $Q$-waves in lead $V_{1}$ was visible in segments 2,3 , and 6. When a $\mathrm{Q}$-wave was found in one or more leads, $109 / 142$ patients $(77 \%)$ had asynergy in one or more segments. Of these 109 patients, $65(60 \%)$ had hypokinesis, 26 patients ( $24 \%$ ) had akinesis, and 18 patients $(17 \%)$ had dyskinesis.

Typical examples of the distribution of segmental wall motion in the presence of Qwaves are given in table XXIV for a $\mathrm{Q}$-wave in lead $\mathrm{AVL}$, table XXV for a $\mathrm{Q}$-wave in lead AVF, table XXVI for a Q-wave in lead $V_{3}$.

TABLE XXIV. DISTRIBUTION OF SEGMENTAL

WALL MOTION IN THE 42 PATIENTS

HAVING A Q-WAVE IN LEAD AVL

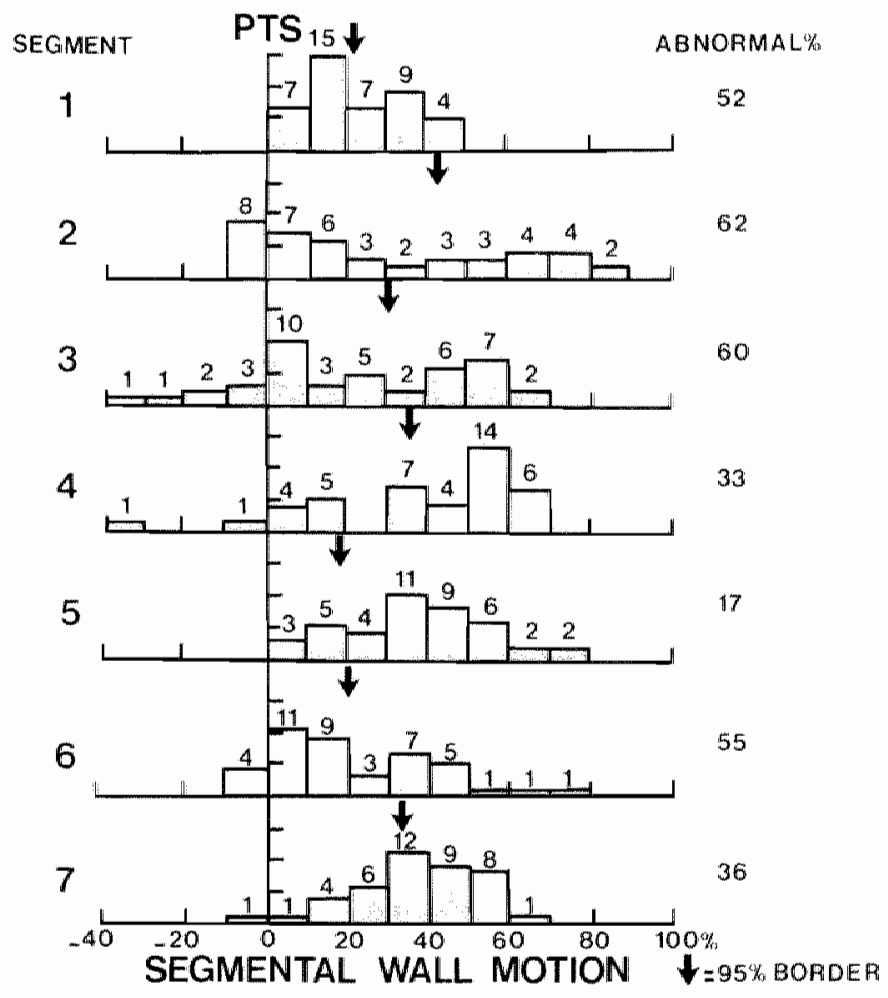



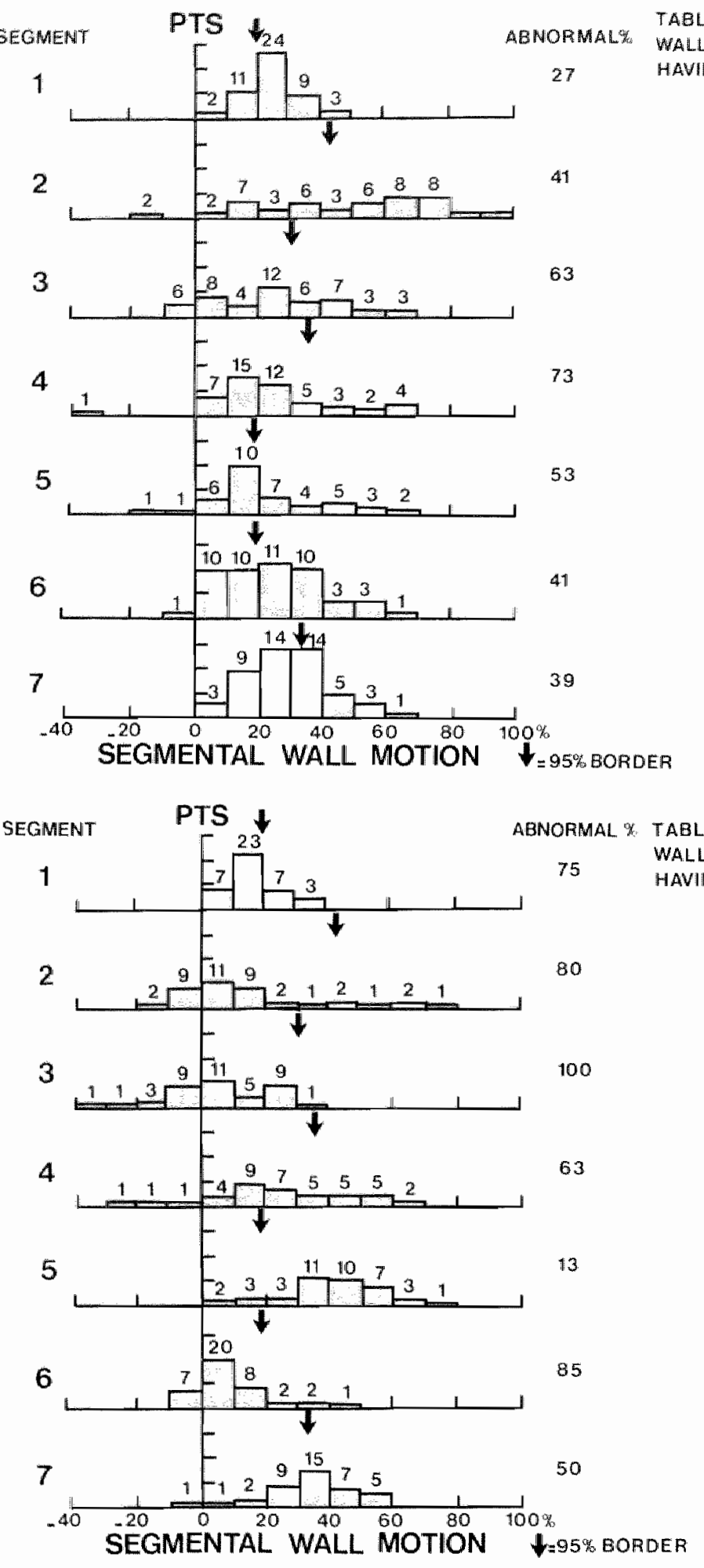
Q-waves were exclusively present in lead III, and not in other leads, in 21 patients. Of these 21 patients, $10(48 \%)$ had synergy. The $\llbracket 1$ patients with asynergy all had hypokinesis, scattered over all segments, but segment 1 . Six of them had hypokinesis in segment 4.

Isolated $\mathrm{Q}$-waves in lead $\mathrm{V}_{1}$ were present in 8 patients. Five of these 8 patients $(62 \%)$ had normal segmental wall motion. The other 3 patients had hypokinesis located in segments 3,4 , and 6 .

One would expect there to be a relation between the number of $Q$-waves and the degree of abnormality of wall motion. In our series we found significant relationship between the number of Q-waves and the degree of asynergy. This is shown in table XXVII. If 3 or more Q-waves were present, none of the patients had an overall normal contraction pattern. In the majority of patients with 4 or more Q-waves, akinesis or dyskinesis was found. The more Q-waves present, the smaller the number of patients having hypokinesis only. If 7 or more Q-waves were present, only aor dyskinesis was seen.

Table XXVII.

The number of $Q$-waves in relation to left ventricular wall motion

\begin{tabular}{|c|c|c|c|c|c|c|c|c|c|c|}
\hline \multirow[b]{3}{*}{ Number of $Q^{\prime} s$} & \multirow{2}{*}{\multicolumn{2}{|c|}{ normal }} & \multirow{2}{*}{\multicolumn{2}{|c|}{ asymergy }} & \multicolumn{4}{|c|}{ Lefo ventricular wall motion } & \multirow{2}{*}{\multicolumn{2}{|c|}{ hypokinesis }} \\
\hline & & & & & & nesis & & & & \\
\hline & $N$ & $\%$ & $N$ & $\mathscr{\%}$ & $N$ & $\%$ & $N$ & $\%$ & $N$ & $\%$ \\
\hline 0 & 90 & 65 & 48 & 35 & 1 & 2 & 5 & 10 & 42 & 88 \\
\hline 1 & 21 & 45 & 26 & 55 & 0 & 0 & 0 & 0 & 26 & 100 \\
\hline 2 & 12 & 34 & 23 & 66 & 1 & 4 & 5 & 26 & 16 & 70 \\
\hline 3 & 0 & 0 & 27 & 100 & 7 & 26 & 5 & 19 & 15 & 56 \\
\hline 4 & 0 & 0 & 8 & 100 & 1 & 13 & 4 & 50 & 3 & 38 \\
\hline 5 & 0 & 0 & 9 & 100 & 4 & 44 & 2 & 22 & 3 & 33 \\
\hline 6 & 0 & 0 & 10 & 100 & 3 & 30 & 5 & 50 & 2 & 20 \\
\hline$\geqslant 7$ & 0 & 0 & 6 & 100 & 2 & 33 & 4 & 67 & 0 & 0 \\
\hline
\end{tabular}

\section{$R / S$-ratio $\geqslant I$ and positive $T$-wave}

Table XXVIII tabulates data on the $R / S$-ratio in leads $V_{1}$ and $V_{2}$, and a positive $T$ wave in lead $V_{1}$ in the presence of an $R / S$-ratio $\geqslant 1$ in lead $V_{1}$ or $V_{2}$. As mentioned previously, patients with wide QRS-complexes were excluded. The best information came from an $\mathrm{R} / \mathrm{S}$-ratio in lead $\mathrm{V}_{1}$. In the presence of that finding, segments 4 and 7 had a high incidence of asynergy. A high $R$-wave in lead $V_{2}$ had a low incidence of abnormalities in segmental wall motion of the $k$ ft ventricle. The incidence of a positive $\mathrm{T}$-wave in lead $\mathrm{V}_{1}$ was higher, but it clid not provide additional information compared to the $\mathrm{R} / \mathrm{S}$ ratio in lead $\mathrm{V}_{1}$. 
Table XXVII

Mean, standard deviation, and percentage of abnormal segmental wall motion in patients with an $R / S$ ratio $\geqslant 1$ in leads $V_{1}$ and $V_{2}$, and a positive $T$-wave in lead $V_{1}$ in the presence of an $R S$ ratio $\geqslant 1$ in leads $\mathrm{v}_{1}$ or $\mathrm{V}_{2}$

\begin{tabular}{|c|c|c|c|c|c|c|c|c|}
\hline & & segme & & & & & & \\
\hline & & 1 & 2 & 3 & 4 & 5 & 6 & 7 \\
\hline Ris-ratio $=\mathbb{\|}$ & mean & 26.3 & 54.9 & 338 & 28.4 & 21.5 & 33.5 & 27.5 \\
\hline$v_{1}$ & S.D. & 10.3 & 24.1 & 19.5 & 18.2 & 11.4 & 17.5 & 17.3 \\
\hline $\mathbb{N}=13$ & abn. $\%$ & 23 & $3 \pi$ & 39 & 69 & 46 & 23 & 69 \\
\hline R/Sratio $=1$ & mean & 30.3 & 60.5 & 41.3 & 42.8 & 33.8 & 37.7 & 39.1 \\
\hline$v_{2}$ & S.D. & 10.1 & 22.8 & 21.0 & 21.7 & 19.6 & 15.1 & 17.0 \\
\hline$N=50$ & $a b m$ & 16 & 24 & 28 & 36 & 28 & 14 & 36 \\
\hline positive $T$ & mean & 27.3 & 54.8 & 36.0 & 33.4 & 24.4 & 332 & 30.3 \\
\hline$v_{1}$ & SD. & 9.7 & 25.2 & 21.3 & 24.2 & 19.3 & 14.6 & 17.8 \\
\hline$N=22$ & abn $\%$ & 23 & 32 & 4 & 59 & 46 & 23 & 64 \\
\hline
\end{tabular}

Abbreviations: as in table XVIII.

Loss of R-wave

Loss of $\mathrm{R}$-wave has less impact on $\mathrm{LV}$ contraction pattern than $\mathrm{Q}$-waves $(78,79)$. If we looked at the significance of a loss of $R$-wave in leads $V_{2}, V_{3}$, and $V_{4}$ on segmental wall motion (table XXIX), we saw that loss of $\mathrm{R}$-wave in lead $\mathrm{V}_{2}$ had the greatest influence on the contraction pattern of the antero-basal, antero-lateral, apical, and septal wall (segments 1, 2, 3, and 6). When the 3 leads were combined, which means that in one or more of the three leads loss of $\mathrm{R}$-wave was present, segments 2,3 , and 6 had a moderate percentage of asynergy. Thirty-two of the 37 patients $(86 \%)$ had asynergy in one or more segments, of which in $7 / 32$ patients $(22 \%)$ segments were dyskinetic, in $8 / 32$ patients $(25 \%)$ akinetic, and in $17 / 32$ patients $(53 \%)$ hypokinetic.

\section{Table XXIX.}

Mean, stundard deviation, and perentage of abnormal segmental wall motion in patients with loss of Rwollage in lostas $V_{2}, V_{3}$, and $V_{4}$

\begin{tabular}{|c|c|c|c|c|c|c|c|c|}
\hline 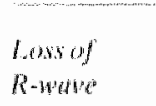 & & Segm & 2 & 3 & 4 & 5 & 6 & 7 \\
\hline $\begin{array}{l}V_{2} \\
N=19\end{array}$ & $\begin{array}{l}\text { mean } \\
\text { S.D. } \\
\text { aba. } \%\end{array}$ & $\begin{array}{c}18.9 \\
9.6 \\
63\end{array}$ & $\begin{array}{l}28.5 \\
32.9 \\
68\end{array}$ & $\begin{array}{l}11.2 \\
19.7 \\
90\end{array}$ & $\begin{array}{l}37.5 \\
23.1 \\
53\end{array}$ & $\begin{array}{l}46.8 \\
22.2 \\
16\end{array}$ & $\begin{array}{l}13.3 \\
13.5 \\
79\end{array}$ & $\begin{array}{l}36.4 \\
10.9 \\
37\end{array}$ \\
\hline $\begin{array}{l}V^{3} \\
N^{2}=19\end{array}$ & $\begin{array}{l}\text { mean } \\
\text { S.D. } \\
\text { abn. } \%\end{array}$ & $\begin{array}{l}26.2 \\
10.6 \\
26\end{array}$ & $\begin{array}{l}42.2 \\
24.3 \\
47\end{array}$ & $\begin{array}{l}28.1 \\
24.4 \\
58\end{array}$ & $\begin{array}{l}44.2 \\
18.0 \\
21\end{array}$ & $\begin{array}{c}45.3 \\
13.8 \\
5\end{array}$ & $\begin{array}{l}22.3 \\
14.3 \\
42\end{array}$ & $\begin{array}{l}42.4 \\
11.4 \\
21\end{array}$ \\
\hline $\begin{array}{l}V_{4}=8 \\
N^{2}\end{array}$ & $\begin{array}{l}\text { mean } \\
\text { S.D. } \\
\text { abn. } \%\end{array}$ & $\begin{array}{l}24.0 \\
13.3 \\
38\end{array}$ & $\begin{array}{l}38.6 \\
29.8 \\
50\end{array}$ & $\begin{array}{l}19.1 \\
27.5 \\
50\end{array}$ & $\begin{array}{l}25.3 \\
13.2 \\
75\end{array}$ & $\begin{array}{l}31.1 \\
21.4 \\
38\end{array}$ & $\begin{array}{l}24.4 \\
19.5 \\
38\end{array}$ & $\begin{array}{l}38.1 \\
10.5 \\
25\end{array}$ \\
\hline $\begin{array}{l}V_{2} \cdot v_{3} \cdot V_{4} \\
N=37\end{array}$ & $\begin{array}{l}\text { mean } \\
\text { S.D. } \\
\text { abn } \%\end{array}$ & $\begin{array}{l}23.4 \\
11.2 \\
43\end{array}$ & $\begin{array}{l}35.4 \\
301.2 \\
60\end{array}$ & $\begin{array}{l}18.3 \\
22.8 \\
73\end{array}$ & $\begin{array}{l}37.8 \\
20.1 \\
46\end{array}$ & $\begin{array}{l}43.9 \\
19.0 \\
14\end{array}$ & $\begin{array}{l}18.6 \\
14.9 \\
60\end{array}$ & $\begin{array}{l}38.9 \\
10.7 \\
27\end{array}$ \\
\hline
\end{tabular}

Abbrevitations: as in table XVIII. 


\section{"Infarct"- ECG}

In order to be able to compare our results with those presented in the literature, we combined electrocardiographic signs of a myocardial infarction. If a Q-wave was present in any of the leads except for leads III and $V_{1}$, or loss of R-wave was seen in the leads $V_{2}$ to $V_{4}$, or lead $V_{1}$ showed an $R / S$-ratio $\geqslant 1$, it was called an "infarct"ECG.

Four localizations for an "infarct"-ECG were used (78):

Anterior "infarct"-ECG: Q-wave and/or loss of R-wave in leads $V_{2}-V_{3}-V_{4}$

Inferior* "infarct"-ECG: Q-wave in leads II-AVF

Posterior "infarct"-ECG: R/S-ratio $\geqslant 1$ in lead $V_{1}$

Lateral "infarct"-ECG: Q-wave in leads I-AVL-V $5-V_{6}$

* A significant percentage of patients having an inferior infarct concomitantly showed involvement of the posterior wall. We were unable to separate these patients from patients having a strictly inferior infarct.

All patients with wide QRS-complexes ( $\geqslant 0.12 \mathrm{sec}$.) were excluded.

The corresponding segments for the various "infarct"-ECGs were defined as follows:

Anterior "infarct"-ECG: segments 2, 3, and 6 .

Inferior* "infarct"-ECG: segments 3, 4, and 7.

Posterior "infarct"-ECG: segments 5 and 7.

Lateral "infarct"-ECG: segment 1.

According to the literature (34), the diagnosis - posterior "infarct"-ECG - was made in the presence of an $R / S$-ratio $\geqslant 1$ in lead $V_{1}$.

Datafrom table XXVIII shows, however, that a positive $T$-wave in the presence of an $\mathrm{R} / \mathrm{S}$ ratio $\geqslant 1$ in lead $\mathrm{V}_{1}$ or $\mathrm{V}_{2}$ should have been included. It would have increased the number of patients with a posterior "infarct"-ECG significantly,

In table XXX distribution of synergy and asynergy is presented, and the latter is subdivided into dyskinesis, akinesis, and hypokinesis. The percentage of abnormal wall motion was approximately the same in all four types of myocardial infarction and varied between 83 and $92 \%$.

Patients with anterior wall infarctions, however, had the highest percentage of dyskinesis: $30 \%$, in contrast to patients with posterior infarctions, where $91 \%$ had hypokinesis only. When we combined all "infarct"-ECGs, 128 patients showed an "infarct"-ECG in one or more sites. In 107/128 patients (84\%) asynergy was found. Eighteen percent of the patients had dyskinesis, $24 \%$ akinesis, and $58 \%$ hypokinesis. 
Left wentricular wall motion in the presence of "Infarct"- ECGs

\begin{tabular}{|c|c|c|c|c|c|c|c|c|c|c|}
\hline \multirow[b]{3}{*}{ "Irfarci" $-E C G$} & \multicolumn{10}{|c|}{ Left yestricular wall notion } \\
\hline & \multicolumn{2}{|c|}{ normal } & \multicolumn{2}{|c|}{ asynergy } & \multicolumn{2}{|c|}{ dyskinesis } & \multicolumn{2}{|c|}{ akinesis } & \multicolumn{2}{|c|}{ hypokinesis } \\
\hline & N & $\%$ & $N$ & $\%$ & N & $\%$ & $N$ & $\%$ & $N$ & $\%$ \\
\hline $\begin{array}{l}\text { Anterior } \\
N=64\end{array}$ & 7 & 11 & 57 & 89 & 17 & 30 & 18 & 32 & 22 & 39 \\
\hline $\begin{array}{l}\text { Inferior" } \\
\mathbb{N}=50\end{array}$ & 4 & 8 & 46 & 92 & 6 & 13 & 11 & 24 & 29 & 63 \\
\hline $\begin{array}{l}\text { Posterior } \\
\mathbb{N}=13\end{array}$ & 2 & 15 & 11 & 85 & 0 & 0 & 1 & 9 & 10 & 91 \\
\hline $\begin{array}{l}\text { Lateral } \\
N=52\end{array}$ & 9 & 17 & 43 & 83 & 9 & 21 & 15 & 35 & 19 & 44 \\
\hline $\begin{array}{l}\text { All } \\
N=128\end{array}$ & 21 & 16 & 107 & 84 & 19 & 18 & 26 & 24 & 62 & 58 \\
\hline $\begin{array}{l}\text { Not present } \\
\mathrm{N}=152\end{array}$ & 102 & 67 & 50 & 33 & 0 & 0 & 5 & 10 & 45 & 90 \\
\hline
\end{tabular}

"Combination with other "Infared"-ECGs are present.

Table XXXI.

Mean, standard deviation, and percentage of abnormal segmental wall motion in patients with an "Infarcl"-ECG

\section{Segment}

\begin{tabular}{|c|c|c|c|c|c|c|c|c|}
\hline "Infarct"-ECG & & $t$ & 2 & 3 & 4 & 5 & 6 & 7 \\
\hline \multirow{3}{*}{$\begin{array}{l}\text { Anterior * } \\
N=64\end{array}$} & mean & 20.8 & 26.8 & 14.4 & 33.5 & 41.3 & 14.5 & 36.6 \\
\hline & S.D. & 11.3 & 29.7 & 23.6 & 21.7 & 17.2 & 15.0 & 13.0 \\
\hline & abn $\%$ & 56 & 70 & 81 & 52 & 13 & 69 & 38 \\
\hline \multirow{3}{*}{$\begin{array}{l}\text { Infiction } \\
N=50\end{array}$} & mean & 24,0 & 45.7 & 24.2 & 23.6 & 22.5 & 23.7 & 28.5 \\
\hline & $\mathrm{S}, \mathrm{D}$ & 9.1 & 28.2 & 21.5 & 19.5 & 17.5 & 16.1 & 13.7 \\
\hline & abn $\%$ & 30 & 42 & 66 & 74 & 54 & 44 & 68 \\
\hline \multirow{3}{*}{$\begin{array}{l}\text { Posterior } \\
N=13\end{array}$} & mean & 26.3 & 54.9 & 33.8 & 28.4 & 21.5 & 33.5 & 27.5 \\
\hline & $S_{4} \mathrm{D}$ & 10.3 & 24.1 & 19.5 & 18.2 & 11.4 & 17.5 & 17.3 \\
\hline & abon. of & 23 & 31 & 39 & 69 & 46 & 23 & 69 \\
\hline \multirow{3}{*}{$\begin{array}{l}\text { Lateral } \\
N=52\end{array}$} & meani & 21.3 & 28.9 & 21.1 & 34.6 & 35.1 & 20.0 & 33.8 \\
\hline & $\mathrm{SD}$ & 11.3 & 29.4 & 24.1 & 21.9 & 17.9 & 18.9 & 15.4 \\
\hline & abn. $\%$ & 52 & 64 & 65 & 46 & 21 & 62 & 42 \\
\hline \multirow{3}{*}{$\begin{array}{l}\text { All } \\
N=128\end{array}$} & mean & 24.4 & 40.9 & 25.1 & 32.9 & 32.4 & 23.4 & 34.6 \\
\hline & $\mathrm{S} D$ & 10.7 & 29.7 & 24.0 & 21.2 & 18.6 & 17.7 & 14.7 \\
\hline & abn. $\%$ & 42 & 49 & 61 & 55 & 32 & 45 & 49 \\
\hline \multirow{3}{*}{$\begin{array}{l}\text { Not present } \\
N=152\end{array}$} & mèan & 32.3 & 65.7 & 48.4 & 50.3 & 38.5 & 38.1 & 45.9 \\
\hline & S.D. & 8.7 & 18.0 & 15.3 & 13.7 & 14.9 & 13.8 & 11.9 \\
\hline & abn. $\%$ & 16 & 19 & 19 & 21 & 15 & 13 & 21 \\
\hline
\end{tabular}

Abbreviations: as in table XVIII.

"Combinations with other "Infarce"-ECGis are present. 
In table XXXI segmental wall motion for the four different types of "infarct"ECGs is given, together with the combination of all "infarct"-ECGs and the patients with a "normal"-ECG. In patients with an anterior "infaret"- $E C G$, the most severe wall motion abnormalities were found in segments 2,3 , and 6 . Patients having an inferior "infarct"-ECG demonstrated $L V$ wall abnormalities in segments 3,4 , and 7. The posterior "infarct"-ECG showed the abnormalities in segments 4 and 7 . The results in a lateral "infarct"-ECG were moderate asynergy in segments 2,3 , and 6 , and to a lesser extent, in segment $1(52 \%)$.

Combination of the possible "infarct"-ECGs were frequently seen (table XXXII). This table also clearly indicates, that in these patients asynergy was commonly found in other than the corresponding segments. This held for all types of "infarct"ECGs. Although the numbers were small, a posterior "infarct"-ECG had the lowest correlation. Only $2 / 5$ patients had asynergy in the corresponding segments.

Table XXXII.

Presence of asynergy in the corresponding and other than the corresponding segments in isolated "Infarct"-ECGs and combinations of. "Infaret"-ECGs

\begin{tabular}{|c|c|c|c|c|}
\hline \multirow[t]{2}{*}{ "Imforct"-ECG } & \multicolumn{2}{|c|}{$\begin{array}{c}\text { Asynergy } \\
\text { corresponding segments }\end{array}$} & \multicolumn{2}{|c|}{$\begin{array}{c}\text { Onher thas } \\
\text { corresponding segments }\end{array}$} \\
\hline & $N$ & $\%$ & $N$ & $\%$ \\
\hline $\begin{array}{l}\text { Anterior } \\
N=29\end{array}$ & 21 & 72 & 22 & 76 \\
\hline $\begin{array}{l}\text { Inferior } \\
N=34\end{array}$ & 30 & 88 & 26 & 76 \\
\hline $\begin{array}{l}\text { Posterior } \\
\mathrm{N}=5\end{array}$ & 2 & 40 & 3 & 60 \\
\hline $\begin{array}{l}\text { Lateral } \\
N=16\end{array}$ & 15 & 94 & $\|$ & 69 \\
\hline $\begin{array}{l}\text { Anterior + Inferior } \\
\mathrm{N}=5\end{array}$ & 5 & 100 & 5 & 100 \\
\hline $\begin{array}{l}\text { Anterior + Lateral } \\
N=26\end{array}$ & 25 & 96 & 21 & 81 \\
\hline $\begin{array}{l}\text { Inferior + Posterior } \\
N=3\end{array}$ & 3 & 100 & 2 & 67 \\
\hline $\begin{array}{l}\text { Inferion }+ \text { Lateral } \\
N=1\end{array}$ & 1 & 100 & 1 & 100 \\
\hline $\begin{array}{l}\text { Posterior + Lateral } \\
N=2\end{array}$ & 2 & 100 & 2 & 100 \\
\hline $\begin{array}{l}\text { Anterior + Inferior + Lateral } \\
N=4\end{array}$ & 4 & 100 & 2 & 50 \\
\hline $\begin{array}{l}\text { Inferior }+ \text { Posterior }+ \text { Lateral } \\
N=3\end{array}$ & 3 & 100 & 3 & 100 \\
\hline
\end{tabular}


Table XXXIII shows the relation between none, one, two, or three localizations of an "infarct"-ECG in one and the same patient. The more numbers of infarcts present, the more severe the impairment of LV function. If 2 or 3 "infarct"-ECGs were present, most patients had a-or dyskinesis.

Table XXXIII.

The number of "Infarct" $\mathrm{ECG}$ in retation tho left ventricular wall motion

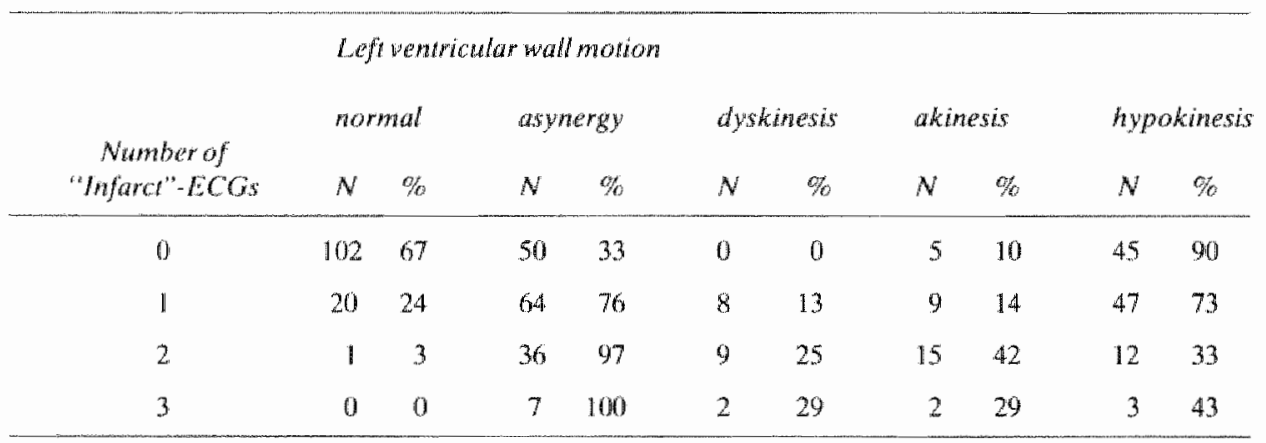

In table XXXIV we can find the distribution of the height of Ply over the "infarct"ECGs in our group of patients. Patients with anterior or lateral "infarct"-ECGs had the highest $P$ ed, patients with posterior "infarct"-ECGs the lowest.

"This data will be discussed in the next chapter.

Table XXXIV.

Correlation beween the height of the loft ventricular end-diastolic pressure and the localization of "In-

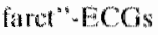

Lefiventricular end-diastolic pressure

\begin{tabular}{|c|c|c|c|c|c|c|}
\hline & & & & & & \\
\hline "Infarct"-ECG & $N$ & $\%$ & $N$ & $\%$ & $N$ & $\%$ \\
\hline Anterior * & 3 & 40 & 17 & 2 & 16 & 75 \\
\hline Inferior * & & & & & & \\
\hline$N=50$ & 23 & 46 & 21 & 42 & 6 & 12 \\
\hline Posterior * & & & & & & \\
\hline$N=13$ & 8 & 62 & 3 & 23 & 2 & 15 \\
\hline Lateral* & & & & & & \\
\hline$N=52$ & 26 & 50 & 14 & 27 & 12 & 23 \\
\hline
\end{tabular}

"Combinations with other "Infarct"-ECGis are present. 
Table XXXV summarizes all results of the correlation between the presence or absence of an "infarct"-ECG and LV wall motion.

Table XXXV.

Correlation between the presence or absence of an "Infact"-ECG and lefe ventricular wall motion

\begin{tabular}{|c|c|c|c|}
\hline & & $N$ & $\%$ \\
\hline "Infaret" "-ECG & Total & $107 / 157$ & 68 \\
\hline \multirow[t]{4}{*}{ Asymergy } & Anterior & 551114 & 48 \\
\hline & Interior & 46138 & 33 \\
\hline & Posterior & 10194 & 11 \\
\hline & Lateral & $27 / 59$ & 46 \\
\hline "Normal" $-\mathrm{ECG}$ & Total & $102 / 123$ & 83 \\
\hline \multirow[t]{4}{*}{ Symergy } & Anterion & $157 / 166$ & 96 \\
\hline & Inferior & $138 / 142$ & 97 \\
\hline & Posterior & $183 / 186$ & 98 \\
\hline & Lateral & 196221 & 89 \\
\hline Asynergy & Total & $107 / 128$ & 84 \\
\hline \multirow[t]{5}{*}{ "Intarcl"-ECG } & Anterion & $57 / 64$ & 89 \\
\hline & Inferior & 46150 & 92 \\
\hline & Posterior & $11 / 13$ & 85 \\
\hline & Lateral & $43 / 52$ & 83 \\
\hline & Combination & $4,3 / 44$ & 98 \\
\hline Asynergy corresponding segments & "Total & $97 / 128$ & 76 \\
\hline \multirow[t]{4}{*}{ "Infarct"- $\mathrm{ECO}$} & Anterior & $55 / 64$ & 86 \\
\hline & Inferior & $43 / 50$ & 86 \\
\hline & Posterior & $9 / 13$ & 69 \\
\hline & Latuteral & $27 / 52$ & 52 \\
\hline Asynergy in other than & Total & $92 / 128$ & 72 \\
\hline corresponding segments & Anterior & $47 / 64$ & 73 \\
\hline \multirow[t]{3}{*}{ "Infarct"-ECO } & Inferior & $40 / 50$ & 80 \\
\hline & Posterior & $10 / 13$ & 77 \\
\hline & Lateral & $43 / 52$ & 83 \\
\hline Asynergy & Total & $50 / 152$ & 33 \\
\hline \multirow[t]{4}{*}{ "Normall"-ECG } & Anteriar & $28 / 152$ & 18 \\
\hline & Inferior & $36 / 152$ & 24 \\
\hline & Posterior & $26 / 152$ & 17 \\
\hline & Lateral & $13 / 152$ & 9 \\
\hline
\end{tabular}

\section{ST-segment}

\section{ST-segment elevation}

Table XXXVT presents the data for ST-segment elevation. It is clear that the presence of ST-segment elevation in any lead, except lead $V_{1}$, and, in al lesser degree, lead III, indicated a high incidence of asynergy. ST-segment elevation in lead II even showed $100 \%$ asynergy in segments 4 and 5 . If ST-segment elevation was present in one or more leads, only $4 / 79$ patients $(5 \%)$ had a normal contraction pattern. If the 12 patients with ST-segment elevation in lead $V_{1}$ were excluded, synergy was present in only $2 / 67$ patients ( $3 \%$ ). Of the other 65 patients, 18 patients ( $28 \%$ ) had 
Table XXXVI.

Mean, standard deviation, and percentage of abnormal segmental wallmotion in patients with ST-segmentefevation

\begin{tabular}{|c|c|c|c|c|c|c|c|c|}
\hline $\begin{array}{l}\text { Sy-segment } \\
\text { elevation }\end{array}$ & & $5 \mathrm{egm}$ & 2 & 3 & 4 & 5 & 6 & 7 \\
\hline 1 & mean & 15.3 & 7.7 & 6.0 & 29.3 & 41.1 & 8.5 & 25.2 \\
\hline \multirow[t]{2}{*}{$N=\|$} & S.D. & 7.6 & 20.3 & 20.2 & 31.6 & 20.0 & 10.5 & 16.1 \\
\hline & abn. \% & 82 & 91 & 91 & 46 & 18 & 91 & 73 \\
\hline II & nuean & 24.2 & 55.3 & 28.2 & 4.0 & 5.8 & 27.3 & 14.7 \\
\hline \multirow[t]{2}{*}{$N=6$} & S.D. & 11.5 & 27.9 & 19.7 & 20.1 & 12.1 & 26.8 & 11.2 \\
\hline & $\operatorname{abn} \%$ & 33 & 33 & 50 & 100 & 100 & 67 & 83 \\
\hline III & mean & 25.9 & 52.3 & 27.7 & 17.5 & 17.1 & 24.8 & 23.4 \\
\hline \multirow[t]{2}{*}{$N=24$} & S.D. & 8.7 & 23.4 & 18.8 & 16.4 & 15.8 & 19.0 & 13.1 \\
\hline & abn. \% & 17 & 33 & 58 & 88 & 63 & 54 & $\pi 1$ \\
\hline AVL & mean & 13.2 & 9.2 & 3.6 & 27.4 & 39.4 & 7.6 & 23.5 \\
\hline \multirow[t]{2}{*}{$N=10$} & S.D. & 5.8 & 20.1 & 21.7 & 32.0 & 17.3 & 11.1 & 16.2 \\
\hline & $\operatorname{abn} . \%$ & 90 & 90 & 90 & 50 & 20 & 90 & 80 \\
\hline$A V F$ & mean & 23.8 & 52.7 & 26.7 & 14.9 & 15.2 & 24.3 & 21.8 \\
\hline \multirow{2}{*}{$N=17$} & S.D. & 7.9 & 22.8 & 16.4 & 16.7 & 16.3 & 17.3 & 12.2 \\
\hline & $a b n . \%$ & 18 & 35 & 65 & 88 & 71 & 53 & 71 \\
\hline$v_{\|}$ & mean & 24.5 & 39.8 & 25.1 & 39.7 & 41.6 & 20.5 & 44.8 \\
\hline \multirow[t]{2}{*}{$N=30$} & S.D. & 10.4 & 34.1 & 28.1 & 17.7 & 15.1 & 17.2 & 110.2 \\
\hline & abn $\%$ & 33 & 47 & 63 & 37 & 7 & 53 & 13 \\
\hline & mean & 17.3 & 16.2 & 7.3 & 31.1 & 41.8 & 10.1 & 36.0 \\
\hline \multirow{2}{*}{$N^{2}=30$} & S.D. & 9.3 & 26.6 & 20.1 & 25.2 & 16.8 & 11.2 & 15.0 \\
\hline & $a b n . \%$ & 70 & 80 & 90 & 50 & 10 & 83 & 30 \\
\hline$v_{3}$ & mean & 17.3 & 15.9 & 5.8 & 27.8 & 4.1 & 8.8 & 34.5 \\
\hline \multirow[t]{2}{*}{$N=35$} & S.D. & 8.9 & 23.7 & 19.4 & 22.9 & 16.9 & 11.6 & 14.6 \\
\hline & abri $\%$ & 71 & 83 & 91 & 57 & 11 & 83 & 43 \\
\hline & mean & 16.8 & 15.4 & 5.0 & 25.4 & 41.4 & 8.3 & 31.9 \\
\hline \multirow[t]{2}{*}{$\mathrm{N}=28$} & S.D. & 9.2 & 24.1 & 17.1 & 23.5 & 17.4 & 11.6 & 14.3 \\
\hline & abn. $\%$ & 68 & 86 & 96 & 61 & 11 & 86 & 46 \\
\hline & mean & 16.5 & 18.5 & 9.3 & 24.1 & 37.4 & 12.1 & 27.11 \\
\hline \multirow[t]{2}{*}{$N=15$} & S.D. & 9.5 & 26.6 & 21.3 & 24.5 & 20.2 & 20.2 & 17.1 \\
\hline & abn. $\%$ & 67 & 87 & 87 & 60 & 27 & 80 & 67 \\
\hline & mean & 14.8 & 19.7 & 9.7 & 22.0 & 26.3 & 15.5 & 19.8 \\
\hline \multirow[t]{2}{*}{$N=6$} & SD. & 7.7 & 30.9 & 20.9 & 22.3 & 24.9 & 27.0 & 8.1 \\
\hline & abn. $\%$ & 83 & 83 & 83 & 67 & 67 & 83 & 100 \\
\hline
\end{tabular}

Abbreviations: as in table XVIII.

dyskinesis, 17 patients ( $26 \%$ ) had akinesis, and 30 patients $(46 \%)$ had hypokinesis. When patients with an "infarct"-ECG were excluded, only 4 patients showed STsegment elevation. One patient had a normal contraction pattern, 2 patients showed hypokinesis, and 1 patient had akinesis.

ST-segment elevation was frequently found in combination with one of the 3 types of "infarct"-ECGs (anterior, inferior, and lateral). In all 3 types of infarction, pre- 
sence of asynergy was found more frequently in patients. with ST-segment elevation, than in patients without this pattern (table XXXVII). In anterior and lateral "infarct"-ECGs, the degree of asynergy was most severe in the group of patients having ST-segment elevation. No difference was seen in patients with an inferior "infarct"-ECG.

\section{Table XXXVII.}

Left ventricular wall motion in the presence of an "Infarct"-ECG with or without ST-segment elevation in those leads

\begin{tabular}{|c|c|c|c|c|c|c|c|c|c|c|c|c|}
\hline \multirow[b]{2}{*}{ "Infarct"-ECG } & & \multirow{2}{*}{$\begin{array}{c}\text { ST-elevation } \\
N\end{array}$} & \multicolumn{2}{|c|}{ normal } & \multicolumn{2}{|c|}{ asynergy } & \multicolumn{2}{|c|}{ dyskinesis } & \multicolumn{2}{|c|}{ akinesis } & \multicolumn{2}{|c|}{ hypokinesis } \\
\hline & & & $N$ & 敏 & $N$ & $\%$ & $N$ & $\%$ & $N$ & $\%$ & $N$ & $\%$ \\
\hline Anterior & absent & 24 & 6 & 25 & 18 & 75 & 2 & 11 & 7 & 39 & 9 & 50 \\
\hline$N=64$ & present & 40 & 1 & 3 & 39 & 97 & 15 & 38 & 11 & 28 & 13 & 33 \\
\hline Inferior & absent & 33 & 4 & 12 & 29 & 88 & 4 & 14 & 7 & 24 & 18 & 62 \\
\hline$N=50$ & present & 17 & 0 & 0 & 17 & 100 & 2 & 12 & 4 & 24 & 11 & 65 \\
\hline Lateral & absent & 35 & 9 & 26 & 26 & 74 & 4 & 15 & 7 & 27 & 15 & 58 \\
\hline $\mathbb{N}=52$ & present & 17 & 0 & 0 & 17 & 100 & 5 & 29 & 8 & 47 & 4 & 24 \\
\hline
\end{tabular}

\section{$S T$-segment depression}

Table XXXVIII shows the effect on segmental wall motion of ST-segment depression at the j-point: these findings, together with ST-segment depression $0.08 \mathrm{sec}$. after the $j$-point, have not been studied previously. A moderate percentage of asynergy in the several segments was seen if this abnormality was present. Again, the postero-basal area (segment 5) showed the lowest incidence of abnormalities. One has to realize, however, that the number of patients showing ST-segment depression in individual leads is rather small.

If ST-segment depression at the j-point was present, $26 / 35$ patients (74\%) had an abnormal contraction pattern.

Asynergy was divided as follows: $1 / 26$ patients (4\%) dyskinesis; $14 / 26$ patients $(54 \%)$ akinesis; and $11 / 26$ patients $(42 \%)$ hypokinesis. ST-segment depression at the j-point, and an "infarct"-ECG, can be present simultaneously. Therefore a subgroup was made, consisting of patients having ST-segment depression without myocardial infarction on the ECG. Twenty-six of the 35 patients $(74 \%)$ had abnormal segmental wall motion in the presence of an infarct. However, of the 9 patients without signs of an "infarct"-ECG, 5 patients $(56 \%)$ had asynergy. Of these 5 patients, none had dyskinesis, $1 / 5$ patients akinesis, and $4 / 5$ patients hypokinesis.

The results of these patients having ST-segment depression $0.08 \mathrm{sec}$. after the $j$ point are presented in table XXXIX. In general, there was a moderately raised percentage of patients having asynergy. In 44 patients ST-segment depression $0.08 \mathrm{sec}$. 
Mean, standard deviation, and percentage of abnormal segmental wall motion in patients with ST-segment depression at j-point

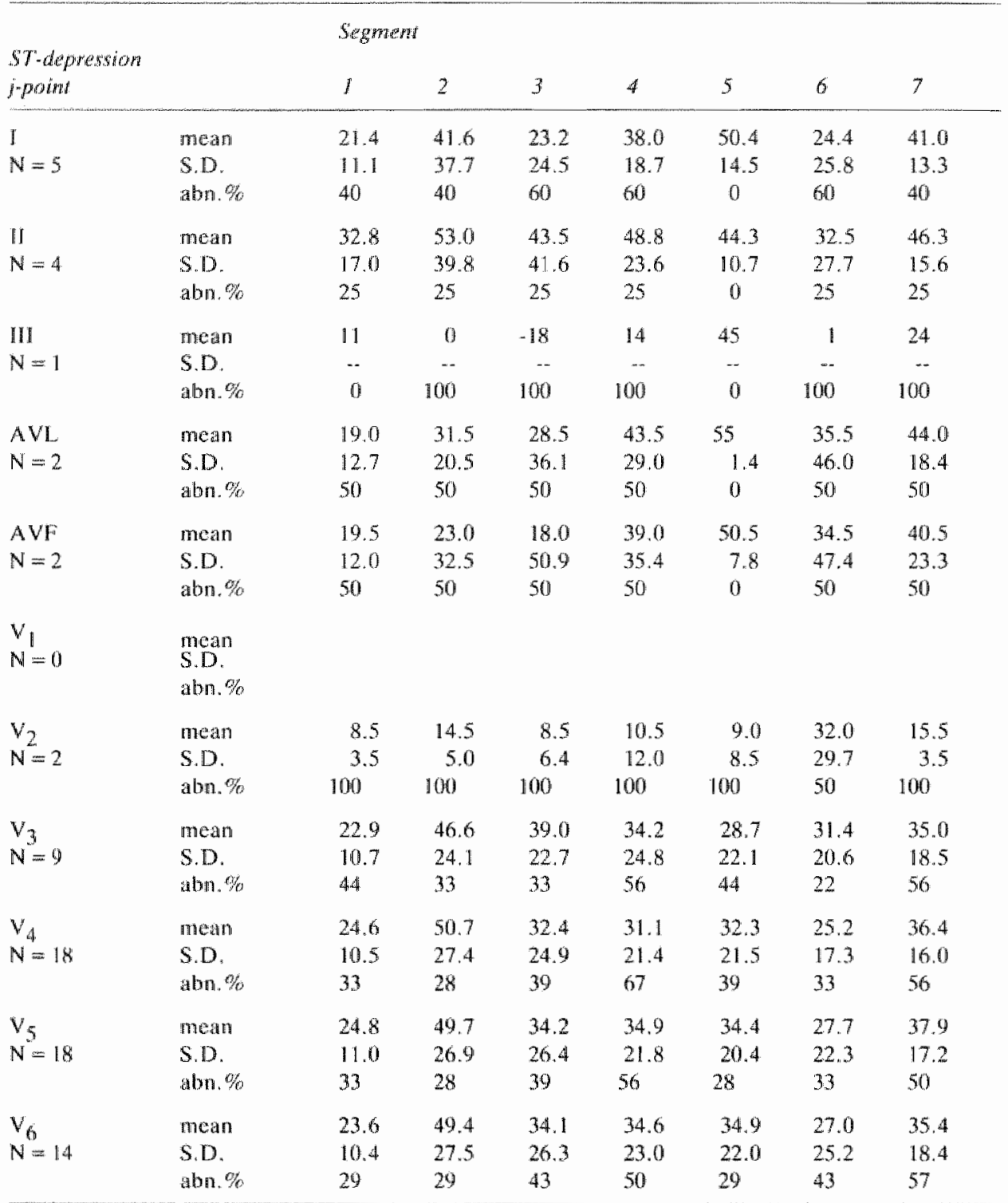

Abbreviations: as in table XVIII.

after the j-point was present in one or more leads. Thirty-three patients (75\%) had asynergy; $3 / 33$ patients $(9 \%)$ had dyskinesis; $14 / 33$ patients $(42 \%)$ had akinesis; and $16 / 33$ patients $(48 \%)$ had hypokinesis. The few patients showing this abnormality in the precordial leads $V_{1}$ and $V_{2}$ had the highest percentage of impairment of wall motion of the left ventricle. In the subgroup of 11 patients without an "infarct"ECG, $5 / 11$ patients ( $45 \%$ ) had asynergy. Of these 5 patients, none had dyskinesis, $1 / 5$ patients had akinesis, and $4 / 5$ patients had hypokinesis. 
Table XXXX.

Mean, standard deviation, and percentage of abnomal segmental wall motion in patients with ST-segment depression $0.08 \mathrm{sec}$ after j-point

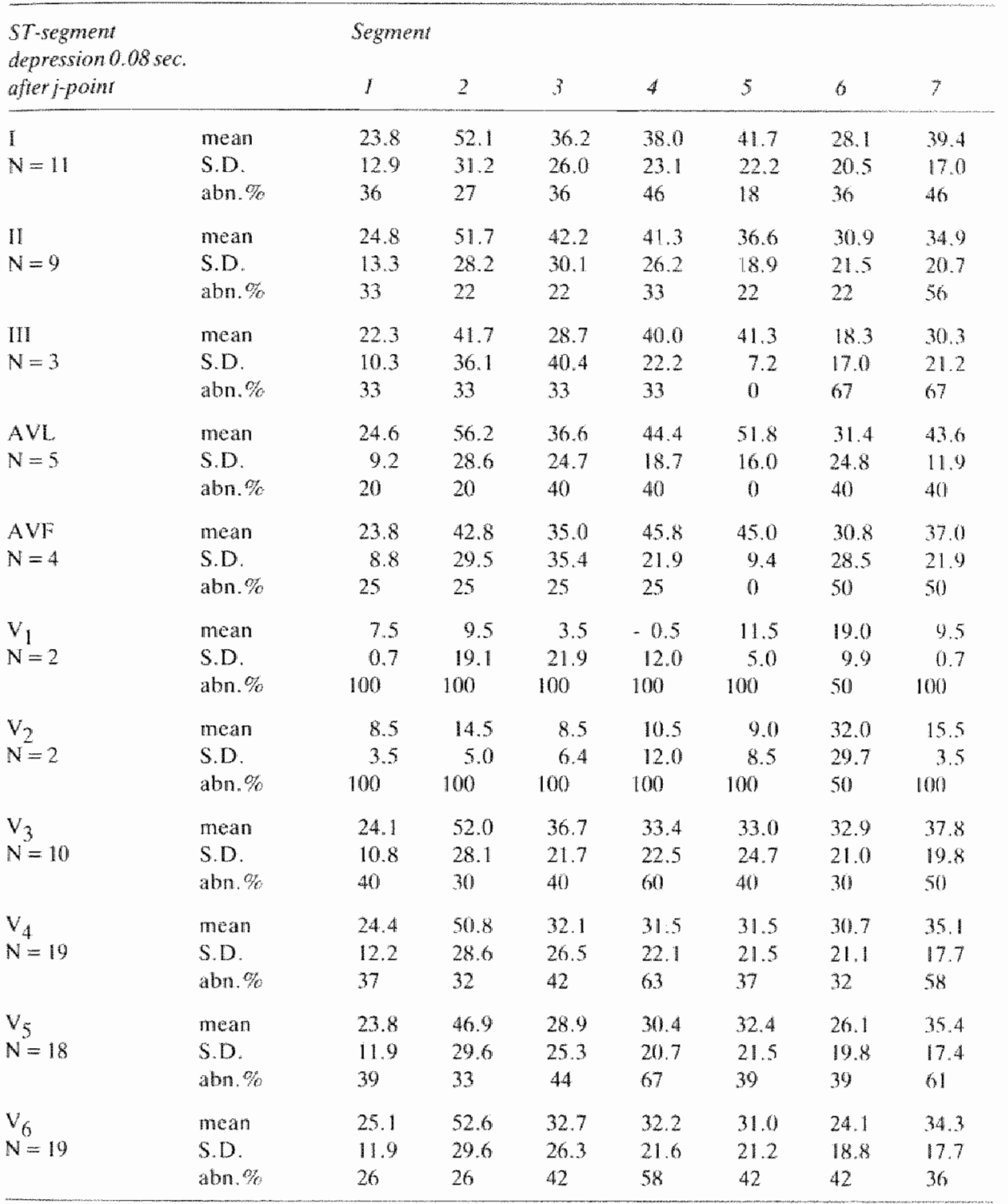

Abbreviations: as in table XVIHI.

\section{T-wave}

Negative T-wave

A negative $T$-wave in lead $V_{2}$ was correlated with a significant incidence of wall motion abnormalities (table XXXX). This table shows that asynergy was found in the 
Mean, standurd deviation, and percentage of abnormal segmental wall motion in patients with negative: Twaves

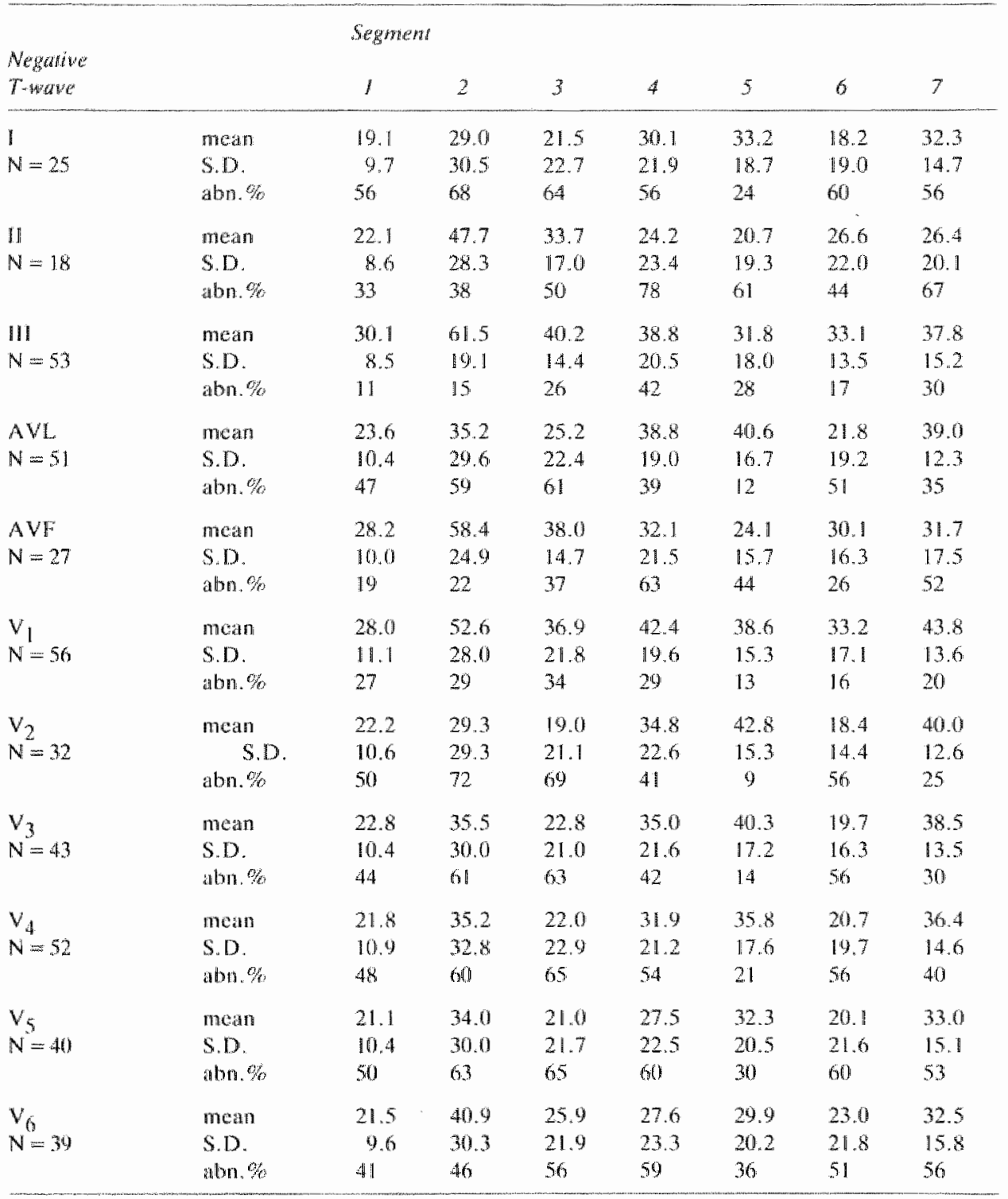

Abbreviations: as in table XVIII.

antero-lateral area (segment 2) in $72 \%$, apical area (segment 3 ) in $69 \%$, and septal area (segment 6 ) in $56 \%$. Leads $\mathrm{V}_{3}$ to $\mathrm{V}_{6}$, $\mathrm{I}$, and $\mathrm{AVL}$ showed a simular finding, but to a lesser extent. A negative $T$-wave in lead II had a significant percentage of abnormal wall motion of segment $4(78 \%)$. Lead AVF was less specific. Thirty-six patients had a negative $T$-wave in one or more of the leads $V_{2}$ to $V_{5}$ in the absence of 
a Q-wave in these leads. Half of these patients had an abnormal contraction pattern in one or more of the segments.

A regative $T$-wave is a frequent and normal finding in lead $V_{1}$. If lead $V_{1}$ was excluded, 127 patients had a negative T-wave in one or more leads. Of these patients, 90 127 (71\%) had asynergy; $12 / 90$ patients (13\%) showed dyskinesis; $23 / 90$ patients (26\%) had akinesis; and 55/90 patients $(61 \%)$ hypokinesis. When the patients with an "infarct"-ECG were excluded, 52 patients remained. Twenty-three of these 52 patients $(44 \%)$ had asynergy. Of these 23 patients, none had dyskinesis, $3 / 23$ patients $(13 \%)$ had akinesis, and $20 / 23$ patients $(87 \%)$ had hypokinesis. 


\section{Chapter 5}

\section{Discussion of the results}

\section{a. Segmental wall motion assessment}

The Stanford group has introduced a new method for LV wall motion assessment using an external reference system, and the $69 \%$ point on the axis between the lateral aortic valve edge and the apex, as origin of the co-ordinate system (1). This method is more accurate compared to 4 other commonly used methods (64).

This new method does, however, have some disadvantages:

1. Although most parts of the Stanford method are objective, determination of the angles $\alpha$ and $\beta$, the definition of the apical segment, the border between the infero-basal segment and the mitral valve, are assessed subjectively.

2. Only the $30^{\circ}$ RAO-projection of the left ventriculography is used.

We have tried to solve these two problems. First, an attempt was made to establish both above mentioned angles in 30 normal patients. Second, apart from using the $30^{\circ} \mathrm{RAO}$-projection, we also introduced a procedure for assessing segmental wall motion in $60^{\circ} \mathrm{LAO}$-projection. In order to establish normal values of segmental wall motion, data from 61 patients with atypical chest pain was analysed. In this group, 14 patients with a prolapse of the mitral valve were included. One might question whether, or not, these patients are acceptable as a control group because they can have LV wall motion abnormalities. These abnormalities, however, are slight contraction and relaxation disturbances and should have no major influence on end-systolic and end-diastolic contours (80-82).

The cut-off point between normal and abnormal segmental wall motion was the $95 \%$ border of the curve at the lower side, where the $95 \%$ border $=$ mean $-1,65 x$ standard deviation (76). This formula can only be used when a normal distribution is present. Although, upon visual inspection the curves looked acceptable, it was not perfect, especially in relation to segment 2 . Insufficient patients were analysed to allow meaningful statistical analysis.

In our control group a $5 \%$ abnormality per segment was present. When total LV wall motion was considered, $21 \%$ of the control patients showed abnormalities in one or more segments where only hypokinetic segments were found. Evaluation of the accuracy of our assumptions is necessary. First, we compared the results of our patients with the data available from the literature (table IV and XXXV). This data is combined in table XXXXI. When comparing results, one has to remember that not only the numbers of some studies are small, but also that methods used both for ECG analysis and LV wall motion assessment differ in these studies. 
Comparison between the results from the literature and this study

\begin{tabular}{|c|c|c|c|c|c|c|}
\hline & & & \multicolumn{2}{|c|}{$\begin{array}{c}\text { Linerature } \\
\text { Number } \\
\text { of studies }\end{array}$} & \multicolumn{2}{|c|}{ This study } \\
\hline & & & $N$ & $\%$ & $N$ & $\%$ \\
\hline "Infarel"-ECG & Total & 5 & $364 / 618$ & 59 & $107 / 157$ & 68 \\
\hline \multirow[t]{4}{*}{ Asynergy } & Anterior & 2 & $64 / 156$ & 41 & $55 / 114$ & 48 \\
\hline & Inferior & 2 & $86 / 183$ & 47 & $46 / 138$ & 33 \\
\hline & Posterior & 2 & $17 / 107$ & 16 & $10 / 94$ & 11 \\
\hline & Lateral & & & & $27 / 59$ & 46 \\
\hline "Normal"-ECG & Total & 3 & $150 / 163$ & 92 & $102 / 123$ & 83 \\
\hline \multirow[t]{4}{*}{ Synergy } & Anterior & 2 & $1 5 7 \longdiv { 1 5 8 }$ & 99 & $157 / 166$ & 95 \\
\hline & Inferior & 2 & $162 / 173$ & 94 & $138 / 142$ & 97 \\
\hline & Posterior & 1 & 83187 & 95 & $183 / 186$ & 98 \\
\hline & Lateral & & & & $196 / 221$ & 89 \\
\hline Asynergy & Total & 7 & $661 / 743$ & 89 & $107 / 128$ & 84 \\
\hline \multirow[t]{5}{*}{ "Infarct" $=\mathrm{BCO}$} & Anterior & 5 & $208 / 228$ & 91 & $57 / 64$ & 89 \\
\hline & Inferior & 6 & $293 / 343$ & 85 & $46 / 50$ & 92 \\
\hline & Posterior & 2 & $10 / 11$ & 91 & $11 / 13$ & 85 \\
\hline & Lateral & & & & $43 / 52$ & 83 \\
\hline & Combination & 3 & $32 / 32$ & 100 & $43 / 44$ & 98 \\
\hline Asynergy corresponding segments & Total & 6 & 4651582 & 80 & $97 / 128$ & 76 \\
\hline \multirow[t]{4}{*}{ "Infarct"-ECG } & Anterior & 5 & $228 / 251$ & 98 & $55 / 64$ & 86 \\
\hline & Inferior & 6 & $248 / 339$ & 73 & $43 / 50$ & 86 \\
\hline & Posterior & 2 & $14 / 20$ & 70 & $9 / 13$ & 69 \\
\hline & Lateral & & & & $27 / 52$ & 52 \\
\hline Asynergy in other than & Tota: & 3 & $101 / 371$ & 27 & $92 / 128$ & 72 \\
\hline owresponding segments & Anterior & 2 & $43 / 137$ & 31 & $47 / 64$ & 73 \\
\hline \multirow[t]{3}{*}{ "Infarel"-ECG } & Interior & 2 & 481182 & 26 & $40 / 50$ & 80 \\
\hline & Posterior & & & & $10 / 13$ & 77 \\
\hline & Lateral & & & & $43 / 52$ & 83 \\
\hline Asynergy & Total & 4 & $182 / 393$ & 46 & $50 / 152$ & 33 \\
\hline \multirow[t]{4}{*}{ "Nomal" $\mathrm{ECG}$} & Anterior & 1 & $32 / 100$ & 32 & $28 / 152$ & 18 \\
\hline & Inferior & 1 & $12 / 100$ & 12 & $36 / 152$ & 24 \\
\hline & Posterior & & & & $26 / 152$ & 17 \\
\hline & Latteral & & & & $13 / 152$ & 9 \\
\hline
\end{tabular}

The results of our study were, in general, comparable with those described in the literature. We lound the same degree of asynergy in patients having an "infarct"ECG. All "infarct"-ECGs had a score for asynergy of 89 and $84 \%$, respectively, both in the literature, and in our study. In anterior "infarct"-ECGs the numbers were 91 and $89 \%$, in inferior "infarct"-ECGs 85 and $92 \%$, and in posterior "infarct"-ECGs 91 and $85 \%$, respectively. In the literature no figures were available for lateral "infarct"-ECGs. We found asynergy in $83 \%$ of the lateral "infarct"ECGs. If combinations of more than 1 infarct localization on the ECG were present, the results were 100 and $98 \%$, respectively, both in the literature and in our study. 
Asynergy of the corresponding segments in patients having an "infarct"-ECG is as frequent in our study as in the literature. Asynergy in other than the corresponding segments was more significant in our study. This was found in $27 \%$ of the total group extrapolated from the literature, as compared to $72 \%$ in our study. These findings were independent of infarct localization. It would seem probable that it is the consequence of our strict definition of corresponding segments, in contrast to the larger areas used in literature. Notably, the lateral and, to a lesser degree, posterior "infarct"- ECGs frequently have wall abnormalities in areas other than in the corresponding ones. These results indicate that precise delineation of the involved segments in the different types of myocardial infarction is not possible. On one hand, these findings can be explained by variations in coronary anatomy or collateral circulation $(83,84)$. On the other hand, because of this overlap with other segments, it clarifies why the different methods for segmental wall motion assessment all correlate with segmental wall motion abnormalities.

Our data agreed with the findings in the literature concerning patients with synergy having a "normal"-ECG. The few studies in the literature, on this subject, found a significant correlation (above $90 \%$ ). Our results showed the same correlation: of our total group of patients with synergy, $83 \%$ showed a "normal"-ECG, patients with anterior synergy had in $95 \%$ a "normal"-ECG, patients with inferior synergy in $97 \%$, and patients with posterior synergy showed in $98 \%$ a "normal"-ECG. We found in patients with lateral synergy a "normal"-ECG in $89 \%$ of the cases.

Patients having asynergy had a lower percentage of "infarct"-ECGs. This was found both in the literature and in our study. In the total group of asynergy patients, $68 \%$ had an "infarct"-ECG in our study, compared to $59 \%$ in the literature. In the literature, patients with inferior wall asynergy more frequently had an inferior "infarct"-ECG than in our study: 47 and $33 \%$, respectively. For anterior and posterior asynergy, the data was similar in the literature and in our study. In lateral asynergy, $46 \%$ of our patients showed a lateral "infarct"-ECG.

If, in the literature, a "normal"-ECG was present, a higher percentage ol asynergy was found than in our study. For the total group these figures were 46 and $33 \%$, respectively. In only one study (27), ECG findings were correlated to the site of asynergy. In contrast to that study, we found a lower incidence in anterior "normal"ECGs, 32 and $18 \%$ respectively, and a higher incidence in inferior "normal"ECGs, 12 versus $24 \%$.

Second, we compared the value of the modified Stanford method with the subjective interpretation of $\mathrm{LV}$ segmental wall motion. Table XVII shows the results of this comparison. A correlation between both methods for synergy and asynergy was found. Only $2 \%$ of the patients with asynergy, using the subjective method, had a normal contraction pattern compared with the objective method. Of the patients with synergy in the subjective method, $13 \%$ proved to have hypokinesis according to the objective method. None of these patients had akinesis or dyskinesis.

These two indirect methods show that the accuracy of our measuring system for LV segmental wall motion is acceptable. Subjective evaluation of LV wall motion, however, has its limitations. Several authors have demonstrated the inconsistency of visual inspection $(45,48,85)$. We believe that this problem cannot be solved, because an absolute method for $\mathrm{LV}$ wall motion assessment is not yet available. 


\section{The value of the $60^{\circ}$ L.AO-projection}

The value of the $60^{\circ} \mathrm{LAO}$-projection was evaluated. In 18/303 patients $(6 \%)$ asynergy was exclusively seen in the $60^{\circ} \mathrm{LAO}$-projection. Arkin (32) was the only investigator who published simular observations, the found exclusive asynergy in $3 \%$ in his series. In 89 of our group of 303 patients (29\%), more severe asynergy was present in the LAO, than the RAO-projection. Fourteen percent was found in Arkin'sseries.

\section{b. Electrocardiogram}

Rautaharju et al (86) developed an ECG coding system to quantify the degree of severity of cardiac injury in myocardial infarction patients. This group proposed a multivariate decision theoretic ECG classification scheme called Cardiac Infarction Injury Score (CIS) by the use of computer reading and interpretation of the ECG. It was developed using ECGs of 387 patients with myocardial infarction and 320 subjects without myocardial infarction.

Fifteen features contributed to the total score weighted for specified ranges of feature values. In this system, not only $\mathrm{Q}$ or $\mathrm{R}$-wave, but also the $\mathrm{ST}-\mathrm{T}$ segment was included for interpretation.

In our study, computer reading of the ECG was not used. In a pilot study we endeavoured to develop a multigrading system for visual ECG interpretation. We also included ST-T changes, notching, axis, voltage, and width of the QRS-complex in ourinterpretation.

Using this system, however, we met two mayor problems:

1. The numbers of patients in the different groups were too small to draw statistical conclusions.

2. The amount of information was far too much even for computer anallysis! More than 300 ECG criteria had to be compared with a percentile scale of shortening of the 7 segments of the $\mathrm{LV}$ wall. These conclusions were reason to reduce the number of electrocardiographic criteria to 66. On the other hand, interpretation of segmental wall motion was reduced to four possibilities: normal, hypokinesis, akinesis, and dyskinesis.

\section{General aspects}

Interesting findings were noted in relation to patients with low voltage, notching, left and right axis deviation, and wide QRS-complexes (tables XVIII-XX).

Low voltage has been found to be a sign of diffuse myocardial involvement (87-89). Ninety-five percent of our patients with low voltage proved to have asynergy. In most patients all segments, except segment 5 , showed a diminished contraction pattern. The most severe abnormalities were found in the anterior wall and apical segment of the left ventricle. As expected this was, in most cases, explicable in terms of a previous myocardial infarction.

It has been well documented that extensive anterior wall infarction results in a significant amount of muscle damage of the left ventricle, resulting in significant loss of $\mathrm{R}$-wave $(9,30,78,79,93)$. This explains the relation between anterior infarcts and low voltage. In our study, 10 of the 22 low voltage patients had an anterior "infarct"-ECG. 
Interesting, but less marked, were the findings in patients with notching. From this group, we excluded patients with wide QRS-complexes for reasons explained previously. Sixty-five percent of these patients (19/29) had, however, asynergy in one or more segments: $53 \%$ of the 19 patients had a- or dyskinesis. In the asynergy patients, the incidence of segmental wall motion abnormalities was the highest in the antero-lateral, septal, and apical areas (segments $2,3,6$ ).

Fibrosis on the basis of a myocardial infarction could be the cause for notching (77). Previous myocardial infarction was present in $17 / 29$ patients.

Right axis deviation in the frontal plane showed that segment 4 (the inferior area) was abnormal in $67 \%$ of cases, which was an unexpected finding. In the presence of an inferior wall infarction, one would expect left axis deviation $(78,90)$. Some patients, however, who suffer an inferior wall infarction, develop block in the left posterior fascicle, which could partly explain the high percentage of abnormal wall motion in segment 4. Patients with left axis deviation had wall motion abnormalities in all segments. As expected, we found the wall motion abnormalities primarily in the inferior and apical areas.

Asynergy seen in our patients having a wide QRS-complex was severe, 2/3 of them showed a- or dyskinesis. Five of the 8 patients with asynergy and right bundle branch block suffered from extensive anterior wall infarction. Two of the 7 patients with left bundle branch block had documented previous myocardial infarction. All 5 patients with atypical bundle branch block had asynergy. In these latter patients, wall abnormalities were present in segments 4 and 7 , suggesting an old infero-posterior lesion. Thus wide QRS-complexes ( $\geqslant 0.12 \mathrm{sec}$.) generally indicate severe segmental wall motion abnormalities. This holds not only for left bundle branch block, but also for atypical bundle branch block.

It is important to stress that wall abnormalities in most patients with right bundle branch block were related to the presence or absence of a previous exlensive anterior wall infarction.

\section{Myocardial infarction}

\section{Previous myocardial infarction}

In patients with a previous myocardial infarction, however, a higher percentage of segmental wall motion abnormalities was present as compared with those who did not have a history of myocardial infarction (table XXI). A significant percentage $(89 \%)$ of patients with a previous infarct had asynergy, compared with only $41 \%$ of patients without a documented myocardial infarction. In a number of patients with a documented myocardial infarction, the ECG changed to a "normal"-ECG. This frequently occurs in inferior infarction, but it is a less frequent finding in anterior wall infarction $(78,91)$.

In our group of 129 patients with one or more previous infarctions, 103 had one, and 26 patients two documented episodes of an infarct (table XXII). In 21 of the 103 patients $(20 \%)$ with one previous infarct, no "infarct"-ECG was recorded at the time of admission for catheterization. There was no specificity in infarct localization.

Twenty-six patients had two documented episodes of a myocardial infarction in the 
past. In $14 / 26$ patients (54\%), the electrocardiographic pattern of an infarct was visible at only one site at the time of admission for catheterization. In most (10) patients, myocardial infarctions previously localized on the inferior or posterior wall, were no longer visible. Cancellation of electrical forces can partly explain this phenomenon.

\section{Q-waves}

Previous studies have determined that there is a close correlation between asynergy and $\mathrm{Q}$-waves.

However, the combined data from four studies $(24,27,29,32)$ indicated that nearly hall of the patients with a "normal"-ECG (46\%) had an abnormal contraction pattern. In our sample, $50 / 152$ patients $(33 \%)$ had asynergy in the presence of a "normal" -ECG; while $17 \%$ of the patients with synergy had an "infarct"-ECG, as compared with $8 \%$ in the literature (table XXXXI). Several explanations can be given for these discrepancies in findings.

\section{Disappearance of infarct Q-waves}

In patients with a previously documented myocardial infarction, the abnormalities may disappear from later repeated ECGs.

a) Abnormal activation of the ventricles, as in hemiblock or left bundle branch block, may conceal the electrocardiographic indicators typical for the presence of myocardial infarction $(43,78,92-94)$.

b) A second episode of myocardial damage may develop. Under such circumstances, the new infarction may produce changes opposite (or reciprocal) to the changes resulting from the previous infarction. This may lead to normalization of the tracing $(78,92)$.

c) In a number of patients with a previously documented myocardial infarction, disappearence of the Q-waves and "normalization of the tracings" can occur $(78,91)$.

\section{Pseudo infarct $\mathrm{Q}$-waves}

a) Cardiomyopathy can simulate myocardial infarction on the ECG in the absence of any narrowing of the coronary arteries (93). Abnormal activation of the ventricles is one of the explanations given for this abnormal finding (95). Bodenheimer et at (29) reported that, while all 21 patients in his study with congestive cardiomyopathy had asynergy, none of these patients had coronary artery disease. However, none of his patients had $\mathrm{Q}$-waves. Of the 7 patients in our study with cardiomyopathy, all had asynergy. In agreement with the findings of Bodenheimer et al, we found that in none of our patients $\mathrm{Q}$-waves were seen, also none of our cardiomyopathy patients had coronary artery disease.

Not only congestive, but also hypertrophic cardiomyopathy and other types of ventricular hypertrophy, diffuse myocardial disease, localized myocardial replacement, the W.P.W.-syndrome, and acute extracardiac events, such as pulmonary embolisn and cerebro-vascular bleeding, may result in Q-waves without infarction $(92,93)$.

b) Presence of a hemiblock or left bundle branch block can also give the pattern of pseudo infarct Q-waves on the ECG (93). 


\section{Abnormal wall motion in the absence of $\mathrm{Q}$-waves}

a) Williams et al (44) showed that severe asynergy can be found in patients with lett bundle branch block in the absence of coronary artery disease. Six of our 7 patients with left bundle branch block had a poor contraction pattern of the left ventricle. However, 2 of the patients with left bundle branch block showed a previous infarct. For these reasons most, but not all authors, in discussing the relationship between "infarct"-ECGs and asynergy, excluded patients with left bundle branch block (24, 26, 30-32).

b) Asynergy does not always relate to scar tissue. Ischaemia can also cause segmental wall motion abnormalities (96). In acute ischaemia $Q$-waves can be present without necrosis off the LV wall (78). This did not apply in our patient material, because none of our patients had an ischaemic episode during the ECG recording. Qwaves are not expected to occur when at least $50 \%$ of the thickness of the LV wall is viable muscle tissue (78).

The degree of asynergy may not be fixed. Nitroglycerine, or post-extrasystolic potentiation, can improve contraction of the left ventricle $(37,97)$. Normalization of LV wall motion after aorta-coronary bypass surgery is also demonstrated $(32,98)$.

The relationship between structural alteration and $L V$ contraction abnormalities has been shown by using light and electronmicroscopy in patients with coronary artery disease (99).

Flameng et al (99) observed that the amount of myocardial fibrosis as assessed by light microscopy was increased only in patients with ECG evidence of previous anterior infarct. This was not seen in patients with asynergy in the absence of an infarct. However, when reduced anterior wall motion was present pre-operatively, extensive myocardial cell degeneration at the ultrastructural level was found in both patients with, as well as those without, previous anterior infarction.

In the patients having anterior asynergy without ECG signs of an anterior wall in. farction, at the ultra-structural level early signs of degeneration were seen in the center of cells; contractile segments were disorganized or had disappeared. This is also shown in dogs (100), where ultrastructural damage of the myocardial cells was clearly visible by $20-40$ minutes of ischemia of the subendocardium. In the infarct patients cell atrophy was advanced with irreversible stages of cell degeneration.

In a second series of 139 patients, Flameng et al (99) performed left ventriculography before, and 8 months after, bypass surgery. In patients with patent grafts to the LV anterior wall, not previously infarcted, reduced anterior wall motion normalized. In patients with previous anterior infarct, the outcome after surgery was unpredictable, but usually wall motion was unimproved.

c) Other cardiac abnormalities, such as myocarditis or longstanding valve disease, may lead to show severe asynergy with a "normal"- ECG (88).

All these considerations help to explain the imperfect relationship between $\mathrm{O}$ waves and asynergy.

\section{Extremity leads}

In patients with $Q$-waves, a significant percentage of segmental wall motion abnormalities was present (table XXIII). Asynergy was not only present in the correspon- 
ding segments, but frequently seen in other segments. For example, Q-waves in lead $A V L$ had in $52 \%$ asynergy of the antero-basal segment. In the same group of patients a higher percentage of asynergy was seen in the antero-lateral $(62 \%)$, apical $(60 \%)$, and septal region $(57 \%)$. Q-waves in lead I were less frequent, but the distribution of asynergy over the above mentioned segments was the same. The explanation for this distribution of segmental wall motion abnormalities was that 36 out of these 52 patients had an anterior wall infarction that extended to the lateral wall. In leads II, III, and AVF an inverse relationship was held between incidence of Q-waves and the percentage of asynergy in all segments. If $Q$-waves were present in the inferior leads, asynergy was most marked in the inferior, postero-lateral, postero-basal, and apical areas.

An increasing frequency of wall motion abnormalities of segment $3,4,5$, and 7 was seen going from lead III to lead A VF to lead II. A Q-wave in lead II reflected severe damage of the left ventricle. The extent of abnormalities of segmental wall motion could be related to the area perfused by the right coronary artery. If a dominant right coronary artery is occluded, not only the inferior, but also the posterior and lateral areas of the left ventricle are frequently involved. Also inaccuracies in precise localization of the segments can play a role in the wide spread of segments involved. In some patients with extensive anterior wall infarction, in whom the left anterior descending branch of the left coronary artery curves over the apex of the left ventricle, Q-waves develop in the inferior leads. This can, in part, explain the combined asynergy observed in the apicalland inferior areas.

An unexpected finding was that of 21 patients with an isolated $Q$-wave in lead III, hypokinesis was present in 11 patients $(52 \%)$, the other 10 patients have the expected normal contraction pattern of the left ventricle. Because of this finding, we recommend reconsideration of interpretation of isolated $\mathrm{Q}$-waves in lead. III.

\section{Precordialleads}

When Q-waves were present in precordial ECG leads, a high incidence of segmental wall motion abnomalities was observed in all, but segment 5 .

Q-waves in lead $V_{1}$ were associated whth less frequent segmental wall motion abnormalities in contrast to the presence of $\mathrm{Q}$-waves in other precordial leads. The most interesting finding was that only $8 \%$ of patients having a $\mathrm{Q}$-wave in lead $\mathrm{V}_{1}$ showed asynergy in segment 5 . In the 8 patients having an isolated Q-wave in lead $V_{1}, 5$ palients $(62 \%)$ had normal segmental wall motion. The other 3 patients showed lypokinesis. Q-waves in leads $\mathrm{V}_{2}$ to $\mathrm{V}_{5}$ were related to asynergy in all segments, except segment 5. Notably when $\mathrm{Q}$-waves were present in leads $\mathrm{V}_{2}, \mathrm{~V}_{3}, \mathrm{~V}_{4}$, and $V_{5}$, abnommalities of wall motion in segment 3 , the apical area, were observed in $95 \%, 100 \%, 93 \%$, and $100 \%$ of pattients, respectively.

As has been described in the literature, anterior wall infarctions have the greatest impact on $\mathrm{LV}$ wall motion $(24,27,29,31,32)$ because occlusion of the left anterior descending artery results in extensive damage of the LV wall.

Of interest was the observation that, apart from a $\mathrm{Q}$-wave in lead II, a $\mathrm{Q}$-wave in lead $V_{6}$ was associated with the highest incidence of abnormal wall motion in segment 5 . Asynergy in segments 4 and 7 was found in a significant percentage (89\% for both segments) if a $Q$-wave was present in lead $V_{6}$. This finding suggests that lead $V_{6}$ should be used as a marker of wall motion abnormalities in the infero-pos- 
terior areas.

It is of great importance that Q-waves, independent of the lead, were frequently associated with a high incidence of segmental wall motion abnormalities. In our study in $77 \%$ of the patients with a $\mathrm{Q}$-wave in one or more leads, lead III and $\mathrm{V}$ included. asynergy was present. Of patients with asynergy, $60 \%$ had hypokinesis, $24 \%$ akinesis, and $17 \%$ dyskinesis.

The finding that in our study the number of $\mathrm{Q}$-waves was strongly associated with the extent of asynergy, is in agreement with the results of Palmeri et al (42) (table XXVII). We found asynergy in $35 \%$ of the patients without $\mathrm{Q}$-waves. However, of these 48 patients, 42 (88\%) had hypokinesis, and only 1 patient had dyskinesis. Of the 47 patients with a single $Q$-wave, $26(55 \%)$ had asynergy. All these patients had hypokinesis. None of the patients with 3 or more $Q$-waves had a normal contraction pattern. The number of patients having hypokinesis was inversely related 10 the number of $\mathrm{Q}$-waves. These abnormalities were not only restricted to the corresponding segment, but could also be found in other segments.

\section{R/S-ratio}

The value of the R/S-ratio in leads $V_{1}$ and $V_{2}$, with or without positive T-waves in lead $V_{1}$, was of less use as an index of asynergy (table XXVIII). In the presence of this abnormality in lead $V_{1}$, asynergy was found in segments 4 and 7 . Lead $V_{2}$ had a low incidence of abnormal segmental wall motion. Lead $\mathrm{V}_{2}$ should not be used to predict asynergy. This accords with the findings of Arkin et al (32). A positive $T$ wave, together with an $R / S-r$ atio $\geqslant 1$ in lead $V_{1}$, had the same incidence of asynergy as the $\mathrm{R} / \mathrm{S}$-ratio in lead $\mathrm{V}_{1}$ alone. The finding of $69 \%$ asynergy in segments 4 and 7 if $R / S$ ratio $V_{1} \geqslant 1$ was, in a number of cases, probably the result of an occluded dominant right coronary artery resulting in an infero-posterior infarction. Q-waves in lead II and lead $V_{6}$ were more indicative of segmental wall motion abnormalities in the postero-lateral segment, than an $R / S$-ratio $\geqslant 1$, and a positive $T$-wave in lead V (table XXIII).

\section{Loss of R-wave}

A loss of $\mathrm{R}$-wave in lead $\mathrm{V}_{2}$ was a more precise indicator of segmental wall motion abnormalities than the presence of this finding in lead $V_{3}$ or $V_{4}$ (table $\left.X X I X\right)$ ). Loss of $\mathrm{R}$-wave in lead $\mathrm{V}_{2}$ was associated with $90 \%$ asynergy in segment 3 . "This finding was also associated with abnormalities in segment $1,2,4$, and 6 , allhough the association was not so definite. In contrast with $Q$-waves in the precondial leads, loss of $R$-wawe or, in other words, the persistence of a small $R$-wave, suggests the presence of viable tissue of the left ventricle in anterior segments. In comparing asynergy in the presence of $\mathrm{O}$-waves and the loss of $\mathrm{R}$-waves in leads $\mathrm{V}_{2}, \mathrm{~V}_{3}$, and $\mathrm{V}_{4}, \mathrm{Q}$-waves showed more damage. In the literature similar results were found $(9,30,78,79,93)$.

\section{"Infarct" - $E C G$}

Asynergy in the various "infarct"-ECGs was in angreement with findings from other studies (tables IV, XXX, and XXXV). The degree of segmental wall motion abnormalities was also similar. Of the group of patients with an anterior "infarct" $\mathrm{ECG}$, $89 \%$ had asynergy. Thirty percent of these asynergy patients had dyskinesis, $32 \%$ 
akinesis, and $39 \%$ hypokinesis.

Miller et al (24), Bodenheimer et al (29), and Arkin et al (32), reported higher percentages of patients with akinesis or dyskinesis than reported from our series. This can be explained by selecting different electrocardiographic criteria as indicative of an anterior infarct. We included patients with loss of $R$-wave in leads $V_{2}$ to $V_{4}$. This resulted in a lower percentage of asynergy in the anterior wall. In patients with an inferior "infarct" -ECG we found in $92 \%$ asynergy and in $63 \%$ hypokinesis. For this type of infarction, our results agreed with those in the literature. Different results compared with those of the literature were found in patients having posterior "infarct"-ECGs. None of the 5 patients from Miller's study (24) had dyskinesis. One patient had a normal contraction pattern, all others had hypokinesis. Arkin et al (32), however, found that in $6 / 15$ patients ( $40 \%$ ) with a posterior infarct, akinesis or dyskinesis was present. We had 13 patients with a posterior "infarct" $E$ ECG. Eleven of these patients had asynergy. Of these 11 patients, 1 patient had akinesis, the other 10 patients had hypokinesis. Whether any significance can be attached to these differences, however, is dubious because the numbers of patients with posterior wall infarction are rather small. One of the reasons of the difference in results of posterior wall infarction was that Arkin (32) used other criteria for the diagnosis posterior infarct. We tend to agree with Arkin that, beside the R/S-ratio $\geqslant 1$ in lead $V_{1}$, the positive T-wave should be included as a criterion for a posterior "infarct". ECG.

In the literature no data was available regarding lateral wall infarctions. We found asynergy in $43 / 52$ patients $(83 \%$ ) with a lateral "infarct"-ECG; subdivided into $21 \%$ with dyskinesis, $35 \%$ with akinesis, and $44 \%$ with hypokinesis.

Our criterion for a lateral "infarct" ECG was the presence of Q-waves in one or more of the leads I, AVL, $V_{5}$, and $V_{6}$. Table XXIII showed, however, that these leads were not specific for the antero-basal area (segment 1). In segments 2, 3, and 6 , an even higher percentage of asynergy was found. The explanation has already been mentioned. Most of the patients also had an anterior "infarct"-ECG.

The other types of "infaret"-ECGs corresponded better with segmental wall motion abnormalities (table XXXI). Anterior wall infarction showed the highest percentage of abnormalities in segments 2,3 , and 6 . Inferior infarction was related to asynergy in segments 3,4 , and 7 , and to a lesser extent in segment 5 . In posterior infarction. segmental wall motion abnormalities were mainly concentrated in segments 4 and 7 , and in a lower percentage, in segment 5 .

After studying these results, one might consider changing the given definition of "infarct"-ECGs and their corresponding segments. This holds especially for the criteria of posterior and lateral "infarct"-ECG.

When all anterior, inlerior, posterior, and lateral "infarct"-ECG patients were combined, 128 patients had an "infarct"-ECG at at least one site (table XXXXXXIII). In 21 of the 128 patients (16\%), normal contraction was found. This was in contrast with 107 of the 128 patients ( $84 \%$ ) with asynergy, of whom $18 \%$ had dyskinesis, $24 \%$ akinesis, and $58 \%$ hypokinesis.

Comparison with the results available from the literature showed that our data was similar with only small variations (table XXXXI). 
Table XXXII showed that in isolated "infarct"-ECGs and in combinations of "infarct"-ECGs, the presence of asynergy in other than corresponding segments was high. In 44 patients combinations of more than one infarct were seen.

The numbers of patients having "infarct"-ECGs in relation to the numbers of patients having asynergy (table XXXII) showed, that patients with 1 "infarct"-ECG had hypokinesis in $73 \%$, while patients with 2 or 3 "infarct"-ECGs had hypokinesis respectively in 33 and $43 \%$. All except 5 of the patients with one infarct on the ECG had hypokinesis.

As shown in table XXXIV, a relationship was found between the "infarct"- ECGs and the height of $P$ ed. Bodenheimer et al (29) found that the $P$ ed was higher in patients with an anterior wall infarction than those having other infarctions. Our patient sample produced similar results in patients with anterior "infarct"-ECGs.

As most patients with lateral "infarct"-ECGs had concomitant involvement of the anterior wall, the group of patients having lateral "infarct"-ECGs showed the same distribution of $P_{\mathrm{ed}}^{l y}$ as the anterior "infarct"-ECG patients.

\section{ST-T segment}

ST-T segment abnormalities can be the result of a previous myocardial infarction.

Several other causes for ST-T segment changes can be given which mimic ECG abnormalities suggestive for an infarct. Acute pulmonary embolism can simulate clinical as well as ECG findings of myocardial infarction $(93,101)$. This did not apply in our patient material. The small group of our patients having a recent episode of longstanding chest pain all showed negative T-waves in the precordial leads. In these patients invariably a high left anterior descending artery stenosis was found. A major cause of ST-segment variations suggestive of myocardial infarction in artifact include damped stylus as well as amplifier low-frequency abnormalities (93). Modern ECG recorders, like the ones we used, do not show this phenomenon.

Most frequently, one encounters ST-segment shifts, the so-called early repolarization changes. Patients having pericarditis also show ST-segment elevation. These ST-segment changes are different from the ones we defined, namely the ST-segment should show a convex pattern which is not present in the patients having pericaritis or early repolarisation.

Cerebro-vascular disorders, hypothermia, hypo- or hyperkalemia, hyperventildtion, mitral valve prolapse, and an episode of abnormal activation of the ventricles (postpacing or posttachycardia), can result in ST-T segment changes which mimic infarction findings (93). Most, but not all, of these abnormalities could be ruled out as the cause of ST-T segment changes in our patient material. On the other hand, ST-segment abnormalities are frequently related to cardiac drugs, like digital lis, and non-cardiac drugs (93). This shows that careful interpretation of our results of ST-T segment abnormalities is essential. On clinical grounds one might expect wall motion abnormalities because ST-segment depression and negative T-waves can be indicative of ischaemia, coexisting with myocardial infarction (78). 


\section{ST-segmentelevation}

When ST-segment elevation was present, severe LV wall abnormalities were found (table XXXVI). In only two of the 9 studies discussed in chapter 3 , attention was paid to $S T$-segment elevation $(24,29)$. Both groups found high percentages of dyskinesis in the presence of ST-segment elevation. Five percent of our patients had a normal contraction pattern in the presence of ST-segment elevation, as compared with $33 \%$ of the patients having Q-waves. Fifty-four percent of the patients with STsegment elevation had dyskinesis or akinesis, in contrast with $42 \%$ of patients exhibiting $\mathrm{Q}$-waves.

Miller et al (24) and Bodenheimer et al (29) reported that ST-segment elevation was commonly found in patients with anterior wall infarctions. We had the same observations, but half of the patients with an inferior "infarct"-ECG also had ST-segment elevation (table XXXVII). Bodenheimer et al (29) stated that ST-segment elevation was an insensitive, but highly specific indicator for an aneurysm. Our findings did not agree with this. In our series, ST-segment elevation together with a convex ST-segment were frequently seen. Our criterion for ST-segment elevation, however, was an elevation above the baseline of $\geqslant 1 / 4 \mathrm{~mm}$ in combination with a convex ST-segment.

Using our criterion, there were only 4 patients who had ST-segment elevation without evidence of a myocardial infarction. Of these 4 patients, one had a normal contraction pattern. ST-segment elevation, together with an "infarct" ECG, showed asynergy in $73 / 74$ patients (99\%) (table XXXVII). If this combination was present, patients with anterior or lateral "infarct"-ECGs were found to have more frequent and more severe asynergy when compared with patients who did not exhibit ST-segment elevation. When we compared segmental wall motion in the combined presence of $\mathrm{Q}$-waves and ST-segment elevation in the extremity leads, it was obvious that in the latter group more frequent asynergy was present than in patients without ST-segment elevation. In this group the severity of the asynergy was not significantly different.

We found $\mathrm{ST}$-segment elevation in one or more leads in $63 \%$ of patients with anterior infarcts, in $32 \%$ with lateral infarcts, and in $34 \%$ with inferior infarcts (table XXXVII). These results indicate that the finding of ST-segment elevation is not only a specific, but also a sensitive indicator for severe damage of the left ventricle.

\section{ST-segment depression}

An interesting group of patients in our study were those showing both ST-segment depression or negative T-waves. None of the previous studies discussed in chapter 3 reviewed the significance of these abnormalities.

\section{ST-segment depression at thej-point}

In our study, a high percentage of patients with ST-segment depression at the $j$ point having asynergy was found (table XXXVIII). If this pattern, however, was seen in the extremity leads, none of the patients had wall motion abnormalities in segment 5 ! One has to realize that the number of patients was small: of 35 patients, $26(74 \%)$ showed abnormalities. Of the 26 asynergy patients with ST-segment depression at the j-point, $58 \%$ had dyskinesis or akinesis. If patients having an "in- 
farct"-ECG were excluded, only 9 patients remained. In this subgroup of 9 patients, only 1 patient had akinesis, while the other 4 asynergy patients had hypokinesis.

\section{$S T$-segment depression 0.08 sec. after the j-point}

Only 2 patients had ST-segment depression $0.08 \mathrm{sec}$, after the j-point in leads $\mathrm{V}_{1}$ and $\mathrm{V}_{2}$ (table XXXIX). Both patients showed generalized wall motion abnormalities. In the extremity leads ST-segment depression was associated with asynergy in a lower percentage compared to ST-segment depression in the precordialleads. In the presence of ST-segment depression in the extremity leads, again segment 5 was infrequently observed to have wall motion abnormalities. When all patients with ST-segment depression 0.08 after the j-point and the patients without signs of an "infarct"-ECG and the latter ST-segment pattern were compared, the incidence of asynergy decreased from $33 / 44$ patients $(75 \%)$ to $5 / 11$ patients $(45 \%)$. The severity of the asynergy also decreased. In the group of the $33 / 44$ patients with ST-segment depression with or without an "infarct" -ECG, 3 patients had dyskinesis, 14 patients had akinesis, and 16 patients hypokinesis. In the other group of patients with STsegment depression, but without an "infarct"-ECG, none of the patients bad dyskinesis, 1 showed akinesis, and 4 hypokinesis.

These results show, that ST-segment depression at the j-point and 0.08 sec. after the $j$-point provide additional information about wall motion. As an independent factor, the value of ST-segment depression in predicting asynergy is limited.

\section{Negative T-waves}

Friedberg (78) pointed out that, although $\mathrm{T}$-wave inversion is the usual finding in cases of nontransmural infarction, differentiation between old and recent myocardial infarction can be difficult. This abnormality is often transient and disappears after a week or so, but in most cases within 3 to 6 months.

In our study, the incidence of negative $T$-waves in the several leads was surprisingly high (table $\mathrm{XXXX}$ ). There was a relationship between the site of the abnormality on the ECG and the segmental wall motion of the corresponding segments. Negative $\mathrm{T}$-waves present in the inferior leads II and AVF were commonly accompanied by asynergy in segments 4 and 7 . In the precordial leads, the equivalent finding was that segments 2,3 , and 6 (the antero-lateral, apical, and septal areas) were abnormal. A negative $\mathrm{T}$-wave in lead $\mathrm{V}_{1}$ is considered a normal linding. When all patients having negative $T$-waves (except in lead $V_{1}$ ) were combined, 90/127 patients ( $71 \%$ ) had asynergy. Twelve of these 90 patients $(13 \%)$ had dyskinesis, 23 patients $(29 \%)$ had akinesis, and 55 patients (61\%) hypokinesis. Asynergy was found in $23 / 52$ patients $(44 \%)$ in whom no signs of an "infaret"-ECG were present. The degree of asynergy in these 23 patients was less severe than in the total group of patients having a negative T-wave. None of the patients had dyskinesis, $3 / 23$ patients ( $13 \%$ ) had akinesis, and $20 / 23$ patients $(87 \%)$ had hypokinesis.

We found that a negative $T$-wave can independently help to predict abnormal $L V$ wall motion.

An interesting subgroup are patients with negative $T$-waves in the precordial leads $\mathrm{V}_{2}$ to $\mathrm{V}_{5}$. In a study done by de Zwaan (102), it was shown that under certain cir- 
cumstances negative $T$-waves in these leads indicated an impending extensive anterior wall infarction. The patients studied by de Zwaan had no or only minimal enzyme rises. In our material, there were 36 patients with negative $T$-waves in lead $V_{2}$ to $V_{5}$ without the presence of $Q$-waves in these leads. Half of these patients had asynergy. 


\section{Chapter 6}

\section{Conclusions}

\section{Left ventricular wall motion assessment}

One of the aims of this study was to standardize quantitatively the Stanford method (1), a method of analysing LV wall motion, to facillitate its general use. We also developed a procedure for segmental wall motion assessment in the $60^{\circ} \mathrm{LAO}$-projection because the Stanford group only used the $30^{\circ} \mathrm{RAO}$-projection.

For wall motion analysis, equivalent to the segmentation commonly used by clinical angiographers, the $30^{\circ} \mathrm{RAO}$-frames were divided into 5 segments: segment 1 : antero-basal; segment 2: antero-lateral; segment 3: apical; segment 4: inferior; and segment 5: postero-basal.

The $60^{\circ}$ RAO-frames were divided into 2 segments: segment 6 : septal; and segment 7: postero-lateral.

To make reproducible measurements possible, in both projections the angles adjoining the several segments were determined. The defined angles showed only reatively small variations because of which they are applicable for general use. Abnormal wall motion (asynergy) was divided into 3 categories: hypokinesis, akinesis, and dyskinesis.

To obtain information about normal segmental wall motion, 61 patients with atypical chest pain were studied. The $95 \%$ border for each segment was taken as the cutoff point between normal and abnormal segmental wall motion.

A limitation of the Stanford method was the difficulty in measuring segment 1 in patients having hyperkinesis of that segment.

This could only be achieved by shifting the systolic contour of segment 1 . This shift did not alter correct interpretation of segment 1.

Our patient material consisted of 303 patients. Coronary artery disease was present in 218 patients, 129 having a documented previous myocardial infarction.

Of the 85 patients without coronary artery disease, 61 patients had atypical chest pain and 24 non-coronary heart disease. A comparison of objective results, using the method described, and subjective interpretation by visual inspection in our 303 patients, showed good correlation. The only area of disagreement between the two methods was in diagnosing hypokinesis. The objective method returned a higher percentage of hypokinesis than the subjective method.

We also compared the results of our objective method with those reported in the literature (table XXXXI). We found that many of our results were similar to those published previously. This held true for our observations on septal and posterolateral wall movement using the $60^{\circ} \mathrm{LAO}$-projection.

These results indicate that the modified Stanford method is acceptable for evaluating the LV segmental wall motion in both $30^{\circ} \mathrm{RAO}$ and $60^{\circ} \mathrm{LAO}$-projections. A higher number of patients with asynergy in other than the corresponding (infaret related) segments was found in our study ( $72 \%$ ) as compared to the studies reviewed in chapter $2(27 \%)$. It seems probable that it is the consequence of our strict definition of corresponding segments, in contrast to the larger areas used in the literature. 


\section{Electrocardiogram}

The second objective of our investigation was to determine the value of the ECG as a predictor of $L V$ wall motion. We did not limit ourselves to assessment of $Q$-waves. Lead AVR was not used during our study.

\section{General aspects}

In the total group of 303 patients, individual segmental wall motion abnormalities were present in $20 \%$ (segment 5 ) to $36 \%$ (segment 3 ) of patients.

It was found that low voltage was accompanied by asynergy in $95 \%$ (21/22 patients) in one or more segments. Asynergy in all segments, except segment 5 , was found in over $50 \%$ of patients with low voltage. Elewen of the 21 patients with asynergy had akinesis or dyskinesis.

A correlation was also found between segmental wall motion and the frontal plane electrical axis. A normal axis had a low incidence, right axis deviation a moderately high incidence, and left axis deviation an almost twofold increase in incidence of segmental wall motion abnormality in all segments compared with the total group of patients.

The 23 patients having wide QRS-complexes $(\geqslant 0,12 \mathrm{sec}$.) had an incidence of wall motion abnormalities for all segments, which was twice as high as the total group of 303 patients. In $87 \%$ of patients asynergy was found in one or more segments, $2 / 3$ of these patients had akinesis or dyskinesis. The patients with wide QRS-complexes were subdivided into three groups: patients having right bundle branch block, left bundle branch block, and atypical bundle branch block.

In all 3 groups incidence of asynergy was high. Five out of 11 patients with right bundle branch block had their conduction disturbance subsequent to an extensive anterior wall infarction. These 5 patients provided most cases of asynergy found in the group with right bundle branch block. This indicates that we had a selected group of patients. Five of the 7 patients with left bundle branch block had generalized disease of the left ventricle. Two of the patients with left bundle branch block had a previous infarction. Although the number of patients is small, our results are more in agreement with the findings of Williams et al (44), than those of Dabizzi (43). We have to realize, however, that none of the patients studied by Williams had coronary artery disease, in contrast to the patients Dabizzi studied, who all suffered this condition. All 5 patients with an atypical bundle branch block had asynergy.

In the evaluation of the significance of all other electrocardiographic findings, the 23 patients having wide QRS-complexes were excluded.

Sixty-five percent asynergy was found in the group of 29 patients showing notching in one or more leads. Nearly half of these patients had akinesis or dyskinesis. In the presence of notching, asynergy was usually localized in segments 2,3 , and 6 , thus demonstrating its relation to anterior infarction.

The incidence of low voltage, wide QRS-complexes, and notching, was low in our patients. The first two patterns were related to severe over-all damage of the left ventricle. In the presence of notching a lesser degree of $L V$ damage was present. 


\section{Myocardial infarction}

\section{Previous Infarct}

In the group of 218 patients with coronary artery disease, 129 patients had a documented myocardial infarction. In patients with a previous infarct, asynergy was four times as frequent as compared to patients without a previous infarct. However, 14/ 129 patients $(11 \%)$ with a previous infarct had synergy in all segments!

Twenty percent of the patients having one episode of a previous infarct showed disappearance of the typical "infarct"-ECG. In these patients, injury of the left ventricle was less severe and less extensive, as compared to patients with a previous infarct who still exhibited an "infarct"-ECG. Of the patients with two previous infarcts, $46 \%$ had an "infarct"-ECG present in 2 areas at the moment of admission for catheterization.

Q-waves

The diagnosis of a pathological $Q$-wave required a $Q$-width $\geqslant 0.04$ sec., or a $Q$-wave voltage $>25 \%$ of the $\mathrm{R}$-wave, or a QS-complex. These Q-waves in any lead were associated with a high incidence of asynergy in all segments. One hundred and nine of the 142 patients $(77 \%)$ with a $\mathrm{Q}$-wave in one or more leads had asynergy. Forty percent of these patients had akinesis or dyskinesis. Most impressive was the significance of $\mathrm{Q}$-waves in the precordial leads $\mathrm{V}_{2}$ to $\mathrm{V}_{5}$. If one excludes segment 5 , severe segmental wall motion abnormalities were found up to $100 \%$. Five of the 8 patients with an isolated $Q$-wave in lead $V_{1}$ showed synergy, the other 3 hypokinesis. $\mathrm{Q}$-waves in lead $\mathrm{V}_{6}$ reflected severe wall motion abnormalities in all segments including segments 5 and 7 . Lead $V_{6}$ was found to provide most information about the posterior areas.

Q-waves in the extremity leads correlated better with more localized abnormalities. Q-waves in the inferior leads II, III, and AVF corresponded with abnormalities in segments 3,4 , and 7 , and the lateral leads I and AVL with segments 1,2,3, and 6 .

Of the 21 patients with an isolated $Q$-wave in lead III, 11 patients had hypokinesis, the other 10 patients had a normal contraction pattern. The greater the number of Q-waves in the 12 lead-ECG, the more severe and extensive the injury of the left ventricle. Three or more $Q$-waves were associated with asynergy in all patients.

\section{$R / S$-ratio and positive T-wave}

The presence of an $\mathrm{R} / \mathrm{S}$-ratio $\geqslant 1$ in lead $\mathrm{V}_{1}$ indicated a high percentage of asynergy in segments 4 and 7 and to a lesser degree in segment 5 . An R/S-ratio $\geqslant 1$ in lead $V_{2}$ indicated a low incidence of asynergy. The presence of a positive T-wave in lead $V_{1}$ showed almost the same percentage of abnormalities in the 7 segments as the R/Sratio in lead $V_{1}$. A positive $T$-wave pattern was, however, present in 22 patients as compared to 13 patients having an R/S-ratio in lead $V_{1}$. The combination of an R/S ratio $\geqslant 1$ and a positive $T$-wave in lead $V_{1}$ was found in 5 patients. All 5 patients had hypokinesis of segment 7 .

\section{Loss of R-wave}

Loss of $R$-waves in leads $V_{2}$ to $V_{4}$ had the same significance as $Q$-waves in these leads. The amount of asynergy, however, was less. 
In conclusion, $Q$-waves in all leads (except for lead $V_{1}$ ), $R / S-$ ratio $\geqslant 1$ in lead $V_{1}$, and loss of $R$-wave in leads $V_{2}, V_{3}$, and $V_{4}$ have a high incidence of asynergy. The $\mathrm{LV}$ wall motion abnormalities are found in the expected segments, but frequently aiso in other areas.

\section{"Infarcl"-ECG}

In an attempt to correlate ECG findings of the 4 classical ECG patterns of myocardial infarction with wall motion abnormalities, 4 groups of leads having a $Q$-wave, loss of R-wave, or an $\mathrm{R} / \mathrm{S}$ ratio $\geqslant 1$ were defined, as were the corresponding $\mathrm{LV}$ wall segments of these 4 types of infarcts (for details see chapter 4 ).

Of the 128 patients having an "infarct"-ECG, 16\% showed synergy. Forty-two percent of the patients with asynergy had akinesis or dyskinesis.

The most severe abnormalities were found in patients with anterior and lateral "infarct"-ECGs. This was true not only for the severity of asynergy, but also for the height of the left ventricular end-diastolic pressure. The patients with an inferior "infarct"-ECG had moderate asynergy and the LV enci-diastolic pressure was lower.

Nearly all patients with a posterior "infarct"-ECG had hypokinesis and most of them had a normal LV end-diastolic pressure.

Asynergy was found not only in the, to the infarct related, corresponding segments $(97 / 128$ patients $=76 \%)$, but frequently also in the other segments $(92 / 128$ patients $=72 \%)$.

As expected, severe asynergy was found when combinations of "infarct"-ECGs were present. Only 1 of the 44 patients with 2 or 3 infarct localizations had a normal contraction pattern of all segments. Of the other 43 patients, $65 \%$ had akinesis or dyskinesis.

\section{ST-segment elevation}

ST-segment elevation was found in 79 patients. This high incidence was the result of our definition requiring an ST-segment elevation of $\geqslant 1 / 4 \mathrm{~mm}$ in combination with a convex ST-segment. Only 4 patients had ST-segment elevation without an "infarct"-ECG. This indicates that our criterion can be used with a low percentage of false positives. ST-segment elevation, in combination with a convex ST-segment, was a very helpful criterion for the presence of asynergy. Extent and severity of asynergy was markedly increased when compared with the presence of $Q$-waves alone. When we excluded lead $V_{1}$, only $3 \%$ of the patients with ST-segment elevation had a normal contraction pattern, and $54 \%$ had akinesis or dyskinesis. Results were particularly impressive when the abnormality was present in the extremity leads. ST-segment elevation was most frequently found in anterior "infarct"-ECGs $(63 \%)$, in inferior "infarct"-ECGs it was seen in $34 \%$, and in lateral "infarct"ECGsin $33 \%$.

Anterior and lateral "infarct"-ECGs in combination with ST-segment elevation had a more severe degree of asynergy, than without this ST-segment abnormality. Compared to inferior infarct patients without ST-segment elevation, patients having ST-segment elevation had a higher frequency of asynergy, but no difference was seen in the degree of asynergy. 


\section{ST-segment depression}

Asynergy was found in 26/35 patients ( $74 \%$ ) with ST-segment depression al the jpoint. However, in only $9 / 35$ patients this abnormality was present without signs of an "infarct"- ECG. Five of these 9 patients had asynergy; 1 akinesis and 4 hypokinesis.

Of the patients with ST-segment depression 0.08 sec. after the $j$-point, $33 / 44 \mathrm{pa}$ tients $(75 \%)$ had asynergy. Of the 11 patients with this ECG pattern in absence of an "infarct"-ECG, akinesis was seen in 1 patient, and hypokinesis in 4 patients.

Thus ST-segment depression either at the $j$-point or $0.08 \mathrm{sec}$. after the $j$-point was usually seen in the presence of an "infarct"-ECG. In the patients without signs of infarction, $50 \%$ had asynergy, most having hypokinesis.

\section{Negative T-waves}

If lead $\mathrm{V}_{1}$ was excluded, negative $\mathrm{T}$-waves were seen in 127 patients. Ninety patients $(71 \%)$ of this group had asynergy. Thirty-nine percent of them had akinesis or dyskinesis. Of the 52 patients without an "infarct"-ECG, 23 patients (44\%) had asynergy, with only $13 \%$ having akinesis and none dyskinesis.

In patients with a "normal"-ECG or an "infarct"-ECG, ST-segment depression and negative T-waves had limited value for predicting segmental wall motion. There was also no definite relation to abnormalities in a certain segment. 


\section{Hoofdstuk 7}

\section{Samenvatting}

\section{De bepaling van de wandbewegingen van de linker kamer}

De opzet van deze studie was onder meer om de Stanford methode (1) voor het bepalen van segmentale wandbewegingen van de linkerkamer te standarizeren, waardoor het mogelijk wordt deze methode algemeen te gebruiken. Hiertoe werd een procedure ontwikkeld om ook de segmentale wandbeweging in de $60^{\circ}$ links voor schuine (LVS) richting te bepalen. Dit was nodig omdat de Sanford groep de wandbeweging alleen in de $30^{\circ}$ rechts voor schuine (RVS) richting bepaalde. Er werd gekozen voor een analyse van de wandbeweging, die aansluit bij de door clinici gebruikte onderverdeling van de wand van de linker kamer.

De $30^{\circ}$ RVS-projectie werd verdeeld in 5 segmenten: segment 1: antero-basaal; segment 2 : antero-lateraal; segment 3 : apicaal; segment 4 : inferior; segment 5: postero-basaal.

De $60^{\circ}$ LVS-projectie werd verdeeld in 2 segmenten: segment 6: septaal en segment 7: postero-lateraal.

Om objectieve beoordeling van beide projecties mogelijk te maken werden de hoeken, die de verschillende segmenten begrensden, vastgesteld. De door ons gedefinieerde hoeken toonden slechts een relatief kleine variatie en zijn daarom geschikt voor algemeen gebruik. Abnormale wandbeweging (asynergie) werd onderverdeelld in drie categorieën: hypokinesie, akinesie en dyskinesie.

Voor het bepalen van de normale segmentale wandbeweging werden 61 patiënten met atypische pijn op de borst bestudeerd. Hierbij werd per segment de $95 \%$ waarde bepaald. Deze waarde werd door ons geaccepteerd als de grens tussen een normale en abnormale segmentbeweging.

Een beperking van de Stanford methode bleek het probleem te zijn segment 1 bij patienten met hyperkinesie van dat segment te meten. Dit kon alleen worden bereikt door de systolische contour van dit segment te verschuiven. Deze verschuiving bleek de diagnostiek van synergie niet te verhinderen.

\section{De paitënten}

Ons patiëntenmateriaal bestond uit 303 patiënten. Tweehonderdtachttien hadden coronarialijden, waarbij 129 patiënten in het verleden een gedocumenteerd myocard infarct hadden doorgemaakt. Van de 85 patiënten zonder coronarialijden hadden 61 patiënten atypische pijn op de borst, terwijl 24 patiënten een niet coronaire hartziekte hadden.

Bij onze 303 patiënten werd een wergelijking gemaakt tussen de objectieve resultaten gebruik makende van de bovengenoemde methode en een subjectieve interpretatie door middel van visuele inspectie van het ventriculogram. Hierbij werd een goede correlatie tussen beide methoden gevonden. Alleen bij een betrekkelijk klein aantal patiënten is volgens de ene methode de diagnose hypokinesie gesteld en volgens de andere methode synergie en vise versa. De objectieve methode liet 
een hoger percentage asynergie zien.

Wij hebben onze objectieve me thode ook geevalueerd door haar te vergelijken met de resultaten uit de literatuur (tabel $\mathrm{XXXXI}$ ). De meeste van onze resultaten waren vrijwel identick aan die van de literatuur. Dit bleek met name ook te gelden voor de bevindingen van de septale en postero-laterale wand in de $60^{\circ}$ LVS-projeclie.

Deze resultaten bewijzen, dat de gemodificeerde Stanford methode een acceptabele manier is om segmentale wandbeweging van de linker ventrikel te bepalen. Dit geld zowel woor de $30^{\circ} \mathrm{RVS}$ als de $60^{\circ} \mathrm{LVS}$-projectie. Wanneer wij onze resultaten vergelijken met die uit de literatuur valt op dat wij bij het ,, infarct"-ECG een veel hoger percentage asynergie vonden in andere dan met het ECG corresponderende segmenten ( $72 \%$ ) dan beschreven wordt in de literatuur (27\%). Deze bevinding is waarschijnlijk een gevolg van onze strikte definitie van corresponderende segmenten in vergelijking met de grotere gebieden, die gebruikt worden in de literatuur.

\section{Het electrocardiogram}

Het tweede doel van ons onderzoek was na te gaan, wat de waarde van het ECG is in het voorspellen van de wandbeweging van de linker kamer. Wij hebben ons hierbij niet alleen tot Q-toppen beperkt. De afleiding AVR werd bij het onderzoek niet gebruikt.

\section{Algemene aspecien}

In de totale groep van 303 patiënten varieerde het percentage abnormale wandbeweging tussen de $20 \%$ (segment 5 ) en $36 \%$ (segment 3 ).

Bij een laag voltage van het QRS-complex bleek $95 \%$ van de patiënten $(=21 / 22 \mathrm{pa}-$ tiënten) asynergie te hebben van een of meerdere segmenten. Met uitzondering van segment 5 had tenminste $50 \%$ van de patiënten met een laag voltage asynergie in alle segmenten. Bovendien was de mate van asynergie bij veel patiënten ernstig. Elf van deze 21 patiënten met asynergie hadden a kinesie of dyskinesie.

Ook werd er een correlatie gevonden tussen segmentale wandbeweging en de electrische hartas in het frontale wak. Bij een normale as werd een lage incidentie, bij rechter asdraziing een matig verhoogde en bij een linker as een bijna 2 maal zo hoge incidentie van abnormale segmentale wandbeweging gevonden als in de totale groep van patiënten. Dit bleek te gelden voor alle 7 segmenten.

Bij de 23 patiënten met een breed QRS-complex $(\geqslant 0,12 \mathrm{sec}$.) werd een dubbel zo hoge incidentie van pathologische wandbewegingen van alle segmenten gevonden als in de totale groep patiënten. Bij $91 \%$ was asynergie van een of meerdere segmenten aanwezig. Tweederde van het aantal patienten had akinesie of dyskinesie. De patiënten met brede QRS-complexen werden onderverdeeld in 3 groepen. Patiënten met een rechter bundeltakblock, een linker bundeltak block en een atypisch bundeltakblock. Alle drie de groepen vertoonden een hoog percentage asynergie. Vije van de 11 patiënten met een rechter bundeltakblock hadden hun geleidingsstoornis ten gevolge van een groot antero-septaal infarct. Dit wijst er op dat we te maken hebben met een geselecteerde groep patiënten. Deze 5 patiënten waren voornamelijk verantwoordelijk voor de pathologie die in deze groep werd gevon- 
den. Vijf van de 7 patiënten met een linker bundeltakblock hadden gegeneraliseerde wandafwijkingen van de linker ventrikel. Alle 5 patiënten met een atypisch bundeltakblock bleken asynergie te hebben.

Wij hebben deze 23 patiënten met brede QRS-complexen uitgesloten van verder onderzoek naar de betekenis van andere electrocardiografische bevindingen.

Bij de 29 patiënten met notching in een of meerdere ECG-afleidingen bleek er bij $65 \%$ van de patiënten asynergie te bestaan. Pathologie werd vooral gezien in de segmenten 2, 3 en 6 waarbij een relatie werd gevonden met een voorwand infarct. Bijna de helft van deze patiënten had akinesie of dyskinesie.

Laag voltage, notching en brede QRS-complexen kwamen betrekkelijk weinig voor bij onze patiënten. Lage voltages en brede QRS-complexen bleken gepaard te gaan met ernstige pathologie van de linker kamer. In beperktere mate geldt dit ook voor notching, hierbij zijn de afwijkingen vooral gelegen in de segmenten $2,3 \mathrm{en} 6$.

\section{Hartinfarct}

\section{Doorgemaakt hartinfarct}

Honderdnegenentwintig van de 218 patiënten met coronarialijden hadden een hartinfarct doorgemaakt. De incidentie van asynergie bleek bij deze 129 patiënten 4 maal hoger te liggen dan bij patiënten zonder een oud infarct. Toch werd nog bij $14 / 129$ patiënten $(11 \%)$ met een oud infarct synergie in alle 7 segmenten gevonden! Bij $20 \%$ van de patiënten, die éénmaal een infarct doormaakten, was het typische ,,infarct"-ECG verdwenen. Bij deze patiënten was de schade aan de linker ventrikel veel minder ernstig en minder uitgebreid dan bij de patiënten waarbij het infarct-beeld wel was blijven bestaan. Patiënten, die twee infarcten doormakten, hadden slechts in $46 \%$ een, ,infarct'-ECG in twee gebieden ten tijde van de opname voor hartcatheterisatie.

\section{Q-toppen}

De diagnose pathologische Q-top werd gesteld als de Q-breedte $\geqslant 0.04 \mathrm{sec}$. was, of er een Q-top voltage $>25 \%$ van de $\mathrm{R}$-top werd gemeten, of een QS-complex aanwezig was. Het vinden van deze $\mathrm{Q}$-toppen in een ECG afleiding bleek samen te gaan met een hoge incidentie van asynergie in alle segmenten. Als een Q-top aanwezig was, bleek er bij $109 / 142$ patiënten ( $77 \%$ ) asynergie te bestaan. Veertig procent van deze patiënten had akinesie of dyskinesie. Het meest indrukwekkend was de betekenis van $Q$-toppen in de precordiale afleidingen $\mathrm{V}_{2}$ tot en met $\mathrm{V}_{5}$. Hierbij werden ernstige segmentale wandbewegingsstoornisen gevonden, soms zelfs in $100 \%$ van de gevallen. Van belang is dat segment 5 hierop een uitzondering vormde. Vijf van de 8 patiënten met geisoleerde $Q$-toppen in afleiding $V_{1}$ hadden synergie, de 3 anderen slechts hypokinesie.

Q-toppen in afleiding $V_{6}$ betekenden ernstige pathologie in alle segmenten, inclusief segment 5 en 7 . Deze afleidingen gaven de beste informatie over de achterwand van de linker ventrikel.

Q-toppen in de extremiteitsafleidingen gingen met meer gelocaliseerde afwijkingen gepaard. Q-toppen in de onderwandafleidingem II, III en AVF correspondeerden 
met afwijkingen in segmenten $3,4 \mathrm{en} 7 \mathrm{en}$ in de laterale afleidingen I en AVL met segmenten 1,2,3en 6 . Bij de 21 patiënten met een geïsoleerde $Q$-top in afleiding III werd bij 11 patiènten hypokinesie gevonden. De andere 10 patiënten hadden een normaal contractiepatroon. Naarmate er meer Q-toppen op het ECG zichtbaar waren, was de beschadiging van de linker kamer des te ernstiger en uitgebreider. Bij 3 of meer $\mathrm{Q}$-toppen bleken alle patienten asynergie te vertonen.

\section{R/S-ration positieve T-top}

Bij aanwezigheid wan een $R / S$-ratio $\geqslant 1$ in afleiding $V_{1}$ bestond er een verhoogd percentage asynergie in segmenten $4 \mathrm{en} 7 \mathrm{en}$ in mindere mate in segment 5 . Een R/ $S$-ratio $\geqslant 1$ in afleiding $V_{2}$ liet een lage incidentie van asynergie zien. Bij aanwezigheid van een positieve $T$-top in afleiding $V_{1}$ werd een vrijwel identiek percentage abnormale wandbeweging in de 7 segmenten gevonden als bij een $R / S$-ratio $\geqslant 1$ in afleiding $V_{1}$. Deze posititieve $T$-top $k$ wam echter vaker voor dan de $\mathrm{R} / \mathrm{S}$-ratio $\geqslant 1$ in afleiding $V_{1}$ : respectievelijk bij 22 en 13 patiënten. De combinatie van beide bevindingen was bij 5 patiënten aanwezig. Al deze. 5 patiënten hadden hypokinesie van segment 7 .

\section{Verlies aan $R$-top voltage}

Het verlies aan $R$-top voltage in de afleidingen $V_{2}$ tot en met $V_{4}$ had dezelfde betekenis als Q-toppen in deze afleidingen. De ernst van de asynergie was echter minder.

\section{"Infarct"-ECG.}

Wij hebben ook de ECG bevindingen die passen bij de 4 klassieke ECG patronen van een myocardinfarct gecorreleerd met afwijkingen in de wandbeweging. Vier combinaties van ECG afleidingen met een $Q$ top, $R$-top afname of een $R / S$ ratio $\geqslant$ $I$ in de diverse afleidingen werden gedefinieerd. De corresponderende segmenten van deze 4 infarcttypen werden vastgesteld (voor details zie hoofdstuk 4).

Van de 128 patiënten met een, infarct"-ECG hadden er $16 \%$ synergie. Twee en veertig procent van de patiënten met asynergie bleken akinesie of dyskinesie te hiebben.

De ernstigste afwijkingen werden gevonden bij patiënten met een anterior of een lateraal, ,infarct"-ECG. Deze bevindingen golden niet alleen voor de ernst van de asynergie maar ook voor de hoogte van de eind-diastolische druk van de linker ventrikel. Bij patiënten met een inferior, ,infarct"-ECG werd matig ernstige asynergie gevonden, terwijl de eind-diastolische druk van de linker ventrikel minder hoog was. Bijna alle patiënten met een posterior, ,infarcl"-ECG hadden hypokinesie, ook de eind-diastolische druk was bij de meesten normaal.

Asynergie werd niet alleen in de bij het infarct behorende (corresponderende) segmenten gevonden $(97 / 128$ patiënten $=76 \%)$, maar vaak ook in de andere segmenten $(92 / 128$ patiënten $=72 \%)$. Volgens verwachting werd bij aanwezigheid van combinaties van, ,infarct"-ECGs een ernstiger mate van asynergie gevonden. Slechts 1 van de 44 patiënten met 2 of 3 infarct localisaties had een normaal contractiepatroon van alle segmenten. Van de andere 43 patiënten bleek $65 \%$ akinesie of dyskinesie te hebben. 


\section{$S T$-segment elevatie}

ST-segment elevatie werd bij 79 patienten gevonden. Deze hoge incidentie is een gevolg van onze definitie van ST-segment elevatie, te weten $\geqslant 1 / 4 \mathrm{~mm}$ in combinatie met een convex ST-segment. Slechts 4 patiënten hadden ST-segment elevatie zonder een, ,infarct"-ECG.

ST-segment elevatie in combinatie met een convex ST-segment blijkt een zeer nuttig criterium te zijn om asynergie te voorspellen. Uitgebreidheid en ernst van de asynergie is belangrijk toegenomen, vergeleken met de aanwezigheid van Q-toppen alleen. Als we afleiding $V_{1}$ uitsluiten, bleek slechts $3 \%$ van de patiënten met ST-segment elevatie een normaal contractiepatroon te hebben, terwij $154 \%$ akinesie of dyskinesie had. Indrukwekkend waren vooral de getallen bij ST-segment elevatie in de extremiteitsafleidingen. ST-segment elevatie werd het vaakste gevonden bij anterior ,,infarct"-ECGs $(63 \%)$. Bij inferior, infarct"-ECGs bleek dit bij $33 \%$ het geval te zijn evenals bij laterale , infarct"-ECGs (33\%). Anterior en laterale ,infarct"-ECGs in combinatie met ST-segment elevatie hadden ernstiger asynergie, dan degenen zonder deze ST-segment afwijking. Als we patiënten met een onderwandinfarct zonder ST-segment elevatie vergeleken met de patiënten met STsegment elevatie, bleek de laatste groep vaker asynergie te hebben. De ernst van de asynergie nam echter niet toe.

\section{$S T$-segment depressie}

Wij hebben gevonden, dat ST-segment depressie op het j-punt in $26 / 35$ patiënten (74\%) samenging met asynergie. Echter bij slechts $9 / 35$ patiënten was deze afwijking aanwezig zonder tekenen van een, ,infarct"-ECG. Vijf van deze 9 patiënten hadden asynergie: 1 patiënt toonde akinesie en 4 hypokinesie.

Van degenen, die ST-segment depressie $0,08 \mathrm{sec}$. na het $j$-punt lieten zien, hadden $33 / 44$ patiënten $(75 \%)$ asynergie. Slechts 11 patiënten hadden dit ECG patroon zonder een ,,infarct'-ECG. Een van hen had akinesie en 4 hadden hypokinesie.

ST-segment depressie hetzij op het $j$-punt of $0,08 \mathrm{sec}$. na het $j$-punt werd meestal samen met een, ,infarct"-ECG gezien. Bij de patiënten die geen tekenen varn cen infarct hadden, bleek $50 \%$ asynergie te vertonen, meestal bestaande uit hypokinesie.

\section{Negatieve T-toppen}

$\mathrm{Na}$ uitsluiting van afleiding $\mathrm{V}_{1}$ waren bij 127 patiënten negatieve T-toppen aanwezig. Negentig patiënten ( $71 \%$ ) van deze groep hadden asynergie. Negen en dertig procent van hen had akinesie of dyskinesie. Van de 52 patiënten zonder een, ,infarct"-ECG hadden 23 patiënten asynergie, waarbij slechts $13 \%$ akinesie hadden en geen enkele patiënt dyskinesie.

Bij patiënten met of zonder Q-toppen bleken ST-segment depressie en negatieve Ttoppen slechts een beperkte waarde te hebben voor het voorspellen van de segmentale wandbeweging. Er werd bovendien geen relatie gevonden met pathologie in een bepaald segment. 


\section{References}

1. Ingels N B . IT, Daughters G T, Stinson E B, AIderman E L:

Evaluation of methods for quantitating lef ventricular segmemal wall motion in man using myocardial markers as a standard. Circulation 61:966, 972, 1980

2. Gemsini G G:

Coronary Arteriography. New York, Futura Publishing Co, 359-371, 1975

3. Berman B, MeGuire J:

Cardiac Aneurysm. Am J Med 8: $480-489,1950$

4. Dubnow M H, Burchell H B, Titus II L:

Postinfarction ventricular aneurysm. Am Heart J 70:753-760, 1965

5. Dressler $\mathbf{W}$, Pfeiffer $\mathbf{R}$ :

Cardiac Aneurysm. Am Int Med 14: 100 - 121, 1940

6. Douglas A H, Sferrazza J, Marici F:

Natural history of aneurysm of ventricle. N Y State J Med 62: 2019-216, 1962

7. Ford R V, Levine H D:

The electrocardiographic clue to ventricular aneurysm. Am lnt Med 34: 998 - 1016, 1951

8. Goldberger E, Schwartx S P:

Electrocardiographic patterns of ventricular aneurysm. Am J Med 4*243-247, 1948

9. Horan L G, Flowers N C, Johnson J C:

Significance of the diagnostic $Q$ wave of myocardial infarction. Circulation $43: 428-436$, 1971

10. Fenichel N M, Kugell V H:

The large Q-wave of the electrocardiogram. A correlation with pathological observations. Am Heart J 7: 235 - 248, 1931

11. Moyer J B, Hiller G I:

Cardiac aneurysm: clinical and electrocardiographic analysis. Am Heart J 41:340-358, 1951

12. Pipilis G A, Wosika P H:

Unipolar precordial electrocardiograms in ventricular aneurysm. IAMA 145: 147 - 152, 1951

13. Steven R A:

Electrocardiographic findings in cardiac ane urysm. Am Int Med 34: 747-758, 1951

14. Gunnar R M, Pietras R J, Blackaller J, Dadmum S E, Szanto P B, Tobin J R Jr:

Correlation of vectorcardiographic crite ria for myocardial infarction with autopsy findings. Circulation 35: 158-171, 1967

15. Wilson F N, Macleod A G, Barker PS, Johnston F D, Klostermeyer L L:

The electrocardiogram in myocardial infarction with particular reference to the initial deflections of the ventricular complex. Heart 16:155-199,1933

16. Myers G B, Klein H A, Hiratzka T:

Correlation of electrocardiographic and pathologic findings in large anterolataral infarcts.

Am Heart J 36: $838-881,1948$

17. Herman M V, Gorlin R:

Implications of left ventricular asynergy. Am J Cardiol 23:538-547, 1969

18. Rackley C E, Dear H D, Baxley W A, Jones W B, Dodge H T:

Left ventricular chamber volume, mass, and function in severe coronary artery disease. Circulation $41: 605-613,1970$

19. Hamilton G W, Murray J A, Kennedy J W:

Quantitative angiocardiography in ischemic heart disease. Circulation 45: 1065-1080, 1972 
20. Moraski R E, Russell R O Jr, Smith M, Rackley C E:

Left ventricular function in patients with and without myocardial infarction and one, two or three vessel coronaryarterydisesse. An $\mathrm{J}$ Cardiol 35: 1- 10, 1975

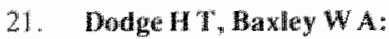

Hemodynamic aspects of heart failure. Am J Cardiol 22: 24-34, 1968

22. Miller GA $H$, Kirklin J W, Swan $\mathrm{H} J C_{\text {: }}$ :

Myocardial function and left ventricular wolumes in acquired valvular insufficienty. Circulation $31: 374-384,1965$

23. Gorlin R, Klein M D, Sullivan JM:

Prospective correlative study of ventricular aneurysm. Am I Med 42: 512 - 531, 1967

24. Miller R R, Amsterdam E A, Bogren H G, Massumi R A, Zelis R, Mason DT:

Electrocardiographic and cineargiographic correlations in assessment of the location. mature and extent of abnormal left ventricular segmental contraction in coronary artery disease. Circulation 49: 447-454, 1974

25. Howard P F, Benchimol A, Desser K B, Reich F D, Graves C:

Correlation of electrocardiogram and vectorcardiogram with coronary occlusion and myocardial contraction abnormality. Am J Cardiol 38: 582 - 587, 1976

26. Mehta J, Hoffman I, Smedresman P, Hilsenrath J, Hamby R I:

Vectorcardiographic, electrocardiograplic, and angiographic correlations in apparently isolated inferior wall myocardial infarction. Am Heart J 91 : 699 - 704. 1976

27. Hamby R I, Hoffman I, Hilsenrath J, Aintablian A, Shanies S, Padmanabhan V S:

Clinical, hemodynamic and angiograhic aspects of inferior and anterior myocardial infarctions in patients with angina pectoris. Am J Cardiol 34: 513-519, 1974

28. MeCaughan D, Turini G, Pipberger HV:

Computer analysis of the Frank electrocardiogram and vectorcardiogram in patients with segmental a reas of akinesia or dyskinesia on left ventricular angiogram. Adv Cardiol 16:246 $-250,1976$

29. Bodenheimer M M, Banka V S, Helfant R H:

$\mathrm{O}$ waves and ventricular asynergy: predictive value and hemodynamic significance of anatomic localization. Am J Cardiol 35: 615 618, 1975

30. Young E, Cohn P F, Gorlin R, Levine H D, Herman M V:

Vectorcardiographic diagnosis and electrocardiographic correlation in left ventricular asynergy due to coronary artery disease. Circulation $51: 595-599,1973$

31. Williums R A, Cohn P F, Vokonas P S, Young E, Herman M V, Gorlin R:

Electrocardiographic, arteriographic and ventriculographic correlations in transmural myocardial infarction. Am I Cardiol 31:595-599, 1973

32. Arkin B M, Hueter D C, Ryan T J:

Predictive value of electrocardiographic patterns in localizing left ventricular asynergy in coronary artery disease. Am Heart 197: 453-459, 1979

33. The Criteria Committee of the New York Heart Association:

Nomenclature and criteria for diagnosis of diseases of the heart and great vessels, 7 th edition. Boston, Little, Brown and Co, $95-125,1973$

34. Massie E, Walsh T J:

Clinicul vectorcardiography and electrocardiography. Chicago, The Year Book Publishers lnc, $255-316,1960$

35. Piplenger H V, Dunn R A, Pipberger H A:

Automated comparison of se rial electrocardiograms. Adv Cardiol 16: 157-165, 1976

36. Banka V S, Bodenheimer M M, Helfant R H:

Determinants of reversible asynergy. The native coronary circulation. Circulation 52: 810 816,1975 
37. Banka V S, Bodenheimer M M, Helfant R H:

Determinants of reversible asynergy. Effect of pathologic $\mathrm{Q}$-waves, coronary collaterals. and anatomic location. Circulation $50: 714-719,1974$

38. Hood W P Jr, Amende I, Simon R, Lichtlen P:

Computer analysis of the effects on ventricular function of intracoronary nitroglycerin Comp in Cardiol, IEEE Computer Society, $425-426,1978$

39. Pasteruac A, Gorlin R, Sonnenblick E H, Haft d I, Kemp H G:

Abnormalities of ventricular motion induced by atrial pacing in coronary artery disease. Circulation 45: $1195-1205,1972$

40. Dwyer E M Jr:

Left ventricular pressure-volume alterations and regional disorders of contraction during myocardial ischemia induced by atrial pacing. Circulation 42:1111-1122, 1970

41. Griffith L S C, Achuff S C, Conti C R, O'Neal Humphries J, Brawley R K, Gott V L, Ross R S:

Changes in intrinsic coronary circulation and segmental ventricular motion after saphenousvein coronary bypass graft surgery. New Eng J Med 288: $589.595,1973$

42. Palmeri S $T_{4}$ Harrison D G, Cobb F R, Morris K G, Harrell F E, Ideker R E, Selvester R H, Wagner G S:

A ORS scoring system for assessing left ventricular function after myocardial infarction. New Eng J Med 306:4-9, 1982

43. Dabizzi R P, Aiazzi L, Caprioli G, Barletta G, Baldrighi V, Fantini F:

Left bundle branch block: a hemodynamic and angiographic study. Eur Heart I 2: 467 - 473, 1981

44. Williams R S, Behar V S, Peter R H:

Left bundle branch block: angiographic segmental wall motion abnomalities. Am I Cardiol 44: $1046-1049,1979$

45. Chaitman B R, DeMots H, Bristow J D, Rösch J, Rahimtoola S H:

Objective and subjective analysis of left ventricular angiograms. Circulation 52: $420-425$, 1975

46. Kuijer P.J P:

De inwloed van een extrasystole op de diastolische linker ventrikelfunctie. Utrecht, Thesis. in press

47. Hammermeister K E, Warbasse 』K:

Immediate hemodynamic effects of cardiac angiography in man. Ant J Cardiol $31: 307-314$. 1973

48. Rogers W J, Smith L R, Hood W P, Mantle J A, Racklley C R, Russell R O :

Effect of filming projection and interobserver variability on angiographic biplane left ventricular wolume determination. Circulation 59:96-104, 1979

49. Lewinson G E Nadimi M, Conrad W A, Hilmi K I:

The effect of angiocardiographic dye on left ventricular volumes. J Clin Invest 45: 1039 . 1966

50. Rahimtoola S H, Duffy J P, Swan $\mathrm{H}_{\mathbf{J}} \mathrm{C}$ :

Ventricular performance after angiocardiography "Circulation 35: 70-78, 1967

51. Friesinger $\mathbf{G}$ C, Schaffer I, Criley I M, Gaertner R A, Ross R S:

Hemodynamic consequences of the injection of radiopaque matterial. Circulation 31 : 730 . 740,1965

52. Leighton R F, Wilt S M, Lewis R P:

Detection of hypokinesis by a quantitative analysis of left ventricular cineangiograms. Circulation 50: $121-127,1974$

53. Harris L D, Clayton P D, Marshall H W, Warner H R:

A technique for the detection of asynergistic motion in the left ventricle. Comp Biomed Res

$7: 380-394,1974$ 
54. Rickards A, Seabra-Gomes A, Thurston P:

The assessment of regional abnormalities of the left ventricle by angiography. Eur J Cardiol $5 / 2,167-182,1977$

55. Vander Wert T:

Klinische pathofysiologie van het hart. Utrecht, Erven J. Bijleveld, Oosthoek's Uitg. BV, $150-154,1974$

56. Chaitman B R, Bristow J D, Rahimtoola S H:

Left ventricular wall motion assessed by using fixed external reference systems. Circulation $48: 1043-1054,1973$

57. Hamilton $G$ W, Murray J A, Kennedly J W:

Quantitative angiocardiography in ischemic heart disease. Circulation 45: 1065 - 1080, 1972

58. Bolson E L, Kliman S, Sheehan F, Dodge HT:

Left ventricular segmental wall motion - A new method using local direction information. Comp in Cardiol, IE EE Computer Society, 245-248, 1980

59. Daughters $\mathbf{G} T$, Ingels $N$, Jang $G$ C, Aldermam $E$ L, Stinson $E$ B:

Left ventricular long axis rotation assessed by cinefluoroscopy of implanted myocardial markers. Fed. Proc 36: 447, 1977

60. Ingels $\mathrm{N} \mathrm{B} \mathrm{Jr}$, Daughters G T , Stinson E B, Alderman E L:

Measurement of midwall myocardial dynamics in intact man by radiography of surgically implanted markers. Circulation 52: $859-867,1975$

61. Ingels $\mathbf{N}$ B Jr, Mead C W, Daughters G T, Stinson E B, Alderman E L:

A new method for assessment of left ventricular wall motion. Comp in Cardiol, IEEE Computer Society, $57-61,1978$

62. Alderman E L, Schwarzkopf A, Ingels N B JR, Daughters G T, Stinson E B, Sanders W J:

Application of an externally referenced, polar coordinate system for left ventricular wall motion analysis. Comp in Cardiol, IEEE Computer Society, 207-210, 1979

63. Daughters G T, Alderman E L, Stinson E B, Ingels N B:

Methods for ventricular wall motion assessment: towards a uniform terminology. Comp in Cardiol, IEEE Computer Society, 145-148, 1979

64. Daughters G T, Schwarzkopf A, Mead C W, Stinson E B, Alderman E L, Ingels N B Jr:

A clinical evaluation of five techniques for left ventricular wall motion assessment. Comp in Cardiol, IEEE Computer Society.249-252.1980

65. Harrison D C, Goldbiatt A, Braunwald E, Glick G, Mason D:

Studies on cardiac dimensilons in intact, unanesthetized man. I. Description of technigues and diefir validation. Circulation Res 13:448 - 467, 1963

66. MeDonald if G :

The shape and movements of the human left ventricle during systole. Am I Cardioll 26:221 $-230,1970$

67. Brower R W, ten Katen H J, Meester G T:

Direct method for determining regional myocardial shortening after bypass surgery from radiopaque markers in man. Am „' Cardiol 41:1222-1229, 1978

68. Rushmer R F, Crystal D K, Wagner C:

The functional anatomy of ventricular contraction. Circulation Res 1: 162-170, 1953

69. Slager C J, Hooghoudt T E H, Reiber J H C, Schuurbiers J C H, Verdouw P D, Hugenholtz PG:

Endocardial landmark motion; a new approach to the assessment of regional left wentricular performance. In Computer analy is of left ventricular cineangiograms, Thesis by Hooghoudt TE H. Rotterdam, 30-58, 1982

70. Mitchell J H, Wildenthal K, Mullins C B:

Geometrical studies of the left ventricle utilizing biplane cinefluorography. Fed Proc 28: $1334-1343,1969$ 
71. Gould K L, Kennedy J W, Frimer M, Pollack G H, Dodge H T:

Analysis of wall dynamics and directional components oft left ventricular contraction in man. Am J Cardiol 38: 322-331, 1976

72. Nie N H, Hull C H, Jenkins J G, Steinbrenner K, Bent D H:

Statistical package for the social sciences, second edition. New York, McGraw-Hill Book Co. 1975

73. Yang S S, Bentivoglio L M S, Maranhao V, Goldberg $H$ :

From cardiac catheterization data to hemodynamic parameters. Philadelphia, $F$ A Davis $\mathrm{Co}, 244-245,1978$

74. Yang S S, Bentivoglio L M S, Maranhao V, Goldberg H:

From cardiac catheterization data to hemodynamic parameters. Philadelphia, F A Davis $\mathrm{Co}, 37,1978$

75. Yang SS, Bentivoglio L MS, Maranhao V, Golldberg $\mathrm{H}$ :

From cardiac catheterization data to hemodynamic parameters. Philadelphia, $F$ A Davis Co, $118-119,1978$

76. De Jonge $\mathbf{H}$ :

Inleiding tot de medische statistiek. Groningen, Wolters Noordhof, 37 and 154 - 170, 1963 1964

77. Holzmann M:

Klinische Elektrokardiographie. Stuttgart, Georg Thieme Verlag, 273-278, 1965

78. Friedberg $\mathbf{C}$ K:

Diseases of the heart. Philadelphia, W B Saunders C0,816-836, 1966

79. Cook R W, Edwards J E, Pruitt R D:

Electrocardiographic changes in acute subendocardial infarction. I. Large subendocardial and non-transmural infarcts. Circulation 18: 603-612, 1958; 11 . Small subendocardial infarcts. Ibid, 18: 613, 1958

80. Cobbs B W Jr:

Clinical recognition and medical management of rheumatic heart disease and other acquired valvular disease. In The Heart, Arteries and Veins, edited by Hurst J W, Logue R B. New York, McGraw-Hill Book Co, 819, 1970

81. Barlow J B, Bosman C K, Pocock W A, Marchand P:

Late systolic murmurs and non-ejection ("mid-latte") systolic clicks: an analysis of 90 pa-

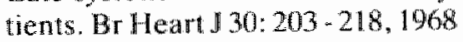

82. Stannard M, Sloman J G, Hare W S C, Goble A J:

Prolapse of the posterior leaflet of the mit rall valve: a clinical, familial and cineangiographic study. Br Med J 3: 71, 1967

83. Herman M V, Eliott W C, Gorlin R:

An electrocardiographic, anatomic, and metabolic study of zonal myocardial ischemia in coronary heart disease. Circulation $35: 834-847,1967$

84. Sesto M, Schwarz F:

Regionall myocardial function at rest and after rapid ventricular pacing in patients after myocardial revascularization by coronary bypass graft or by collateral vessels. Am J Cardiol 43 : $920-928,1979$

85. Hooghoudt T E H, Slager C J, Reiber J H C, Brower R W, Castellanos S, Zorn I C J, Hugenholltz P G:

Observer variability in the visual assessment or regional wall motion and in computer assisted analysis of regional left ventricular function. In Computer analysis of left ventricular cineangiograms, Thesis by Hooghoudt T E H. Rotterdam, $98-110,1982$

86. Rautaharju P M, Warren J W, Jain U, Wolf H K, Nielsen C L :

Cardiac infarction injury score: an electrocardiographic coding scheme for ischemic heart disease. Circulation 64: $249-255,1981$ 
Practical electrocardiography. Baltimore, The Willams and Wikins Co, 309,1976

88. Wynne J, Branwald E:

The cardiomyopathies and myocardindes. In Heart disease. A textbook of cardiovascular medicine, edited by Braunwald $E$. Philadelphia, W B Saunders Co, 1469, 1980

89. Holzmann M:

Klinische Elektrokardiographie. Stutgant, Georg Thieme Verlag 186 - 190, 1965

90. Curd G W Jr, Hicks W M Jr, Gyorkey F:

Marked left axis dewation indicalion of cardiac abnormality. A m Heart J 62:462-469, $196 \mathrm{I}$

91. Kaplan B M, Berkson D M:

Seriat electrocardiograms after myocardial infarction. Ann Int Med 60: 430, 1964

92. Marriott HJL:

Practical electrocardiography. Baltimore. The Williams and Wilkins Co, 240-246, 1976

93. Mandel W J, Peter C T, Homan I:

Elect rocardiographic diagnotic dilemmas in myocardial ischemia and infarction. In What"s new in electrocardiography, edited by Wellens $\mathrm{H} \mathrm{J} \mathrm{J,} \mathrm{Kulbertus} \mathrm{H}$ E. The Hague, Boston, London, Martinus Nyhoff Publishers, 58 - 78, 1981

94. Wackers F J T, Lie K J, David G, Koster R M, Wellens H J J:

Assessment of the value of electrocardiogrpahic signs for myocardial infarction in left bundle branch block. In What's new in electrocardiography, edited by Wellens $\mathrm{H} J \mathrm{~J}$, Kulbertus HE. The Hague, Boston, London, Martinus Nyhoff Publishers, 5837-57, 1981

95. พ. Dam R T, Roos J P, Durrer D:

Electrical activation of ventricles and interventricular septum in hypertrophic obstructive cardiomyopathy. Br Heart J 34: 100 - 112, 1972

96. Horan L, G, Flowers N C:

Electrocardiography and vectorcardiography. In Heart disease. A textbook of cardiovascular medicine, edited by Braunwald E. Philadephia, W B Saunders Co, 234-246, 1980

97. Helfant H R, Banka V S:

A clincal and angiographic approach to coronary heart disease. Philadelphia, F A Devis Co, $135-136.1978$

98. Helfant H R, Banka V S:

A clinical and angiographic approach to coronary heart disease. Philadephia, FA Davis Co, $216-217,1978$

69. Fameng W, Suy R, Schwar2 F, Borgers M, Piessens J, Thone F, Van Ermen H, de Geest H: Uitrastructural correlates of lleft ventricular contraction abnormalities in patients with chronic ischemic hearl disease: determinats of reversible segmental asynergy postrevascularization surgery. Am Heart I 102: 846-857, 1981

400. Klonem $R$ A, Rude R E, Carison N, Maroko PR, DeBoer $\mathbb{L}$ M V, Braunwald E:

Ulerastructural evidence of microvascular damage and myocardial cell injury after coronary arlery ocdusion: which comes first? Circulation 62:945-952,1980

101. Brugada $P$, Gorgels $A P_{\text {, }}$, Wellems $H$, J :

The electrocardiogram in pulmonary embolism. In What's new in electrocardiography, edited by Wellens H IJ, Kulbertus HE. The Hague, Boston, London Martinus Nyhoff Publishers. $366-380,1981$

102. de Zwaan C:

Een typisch ECG patroon, wijzende op een kritische stenose hoog in de linker anterior descendens coronair arterie, bij patienten opgenomen wegens een dreigend hart infarct. Hart Bull13:39-41.1982 


\section{Curriculum Vitae}

Frits W.H.M. Bär was born on the 25th of May, 1942 in Roermond, the Netherlands. After completing grammar school in Roermond, he studied at the Medical Faculty of the University of Nijmegen, and graduated in 1969.

His primary goal was to become a general practitioner. Therefore a training was done in surgery, internal medicine, and cardiology in St. Joseph Hospital, Venlo, and gynaecology and paediatric medicine in St. Willibrord Hospital, Tegelen and in St. Antonius Hospital, Horst.

During this period of time his interest in cardiology was aroused, especially by the stimulating approach of Dr. P.M.H.G. Troquay. Therefore in 1970 he became a trainee of internal medicine at the St. Elisabeth Hospital, Tilburg (Head: Dr. V.A.M. Terwindt). Two years later he joined the Wilhelmina Gasthuis, Amsterdam, for his cardiology training (Heads: Prof. Dr. D. Durrer and Prof. Dr. H.J.J. Wellens).

In July, 1975, he was registered as a cardiologist and continued to work in the Wilhelmina Gasthuis as staff member of the Department of Cardiac Surgery (Head: Prof.Dr. N.G. Meyne).

In 1977 he was invited by Prof.Dr. H.J.J. Wellens to join the latter to the University of Limburg in Maastricht. In five years time, they developed, with the help of many others, a cardiology department in the St. Annadal Hospital, which is very active in teaching, research, and most important of all, in taking care of patients.

In these five years he paid special attention to the cardiology ward, the trainees, the catheterization laboratory, and the organizational work of the Department of Cardiology and the Cardiological Faculty Group. He also was very active in cardiac rehabilitation. In collaboration with Dr. W. Jobse, cardiac rehabilitation, especially for cardiac surgery patients, was founded in the St. Lucas Rehabilitation Centre Hoensbroek. He also has set up the availability of specialized rehabilitation guidance groups outside of the hospital, where physiotherapists, together with "ex"patients and their partner, concentrate on recovering physical and mental conditions. Because ol his activities, cardiac rehabilitation is now also present in the $\mathrm{St}$. Annadal Hospital, Maastricht. 